\title{
LIBERALIZAÇÃO COMERCIAL NO BRASIL E INTEGRAÇÃO NOS MERCADOS DE COMMODITIES AGRÍCOLAS: OS MERCADOS DE ALGODÃO, MILHO E ARROZ
}

\author{
SÍLVIA MARIA ALMEIDA LIMA COSTA
}

Orientador: Prof. Dr. JOAQUIM BENTO DE SOUZA FERREIRA FILHO

Tese apresentada a Escola Superior de Agricultura "Luiz de Queiroz", Universidade de São Paulo. para obtenção do título de Doutor em Ciências, Área de Concentração: Economia Aplicada

P I R A C I C A B A

Estado de São Paulo - Brasil

Julho - 1999 


\begin{tabular}{|c|c|c|}
\hline \multicolumn{3}{|c|}{ ERRATA } \\
\hline Página & Onde se lê: & Lê-se: \\
\hline 16 & Valorização da taxa de câmbio & valorização da moeda \\
\hline 53(quadro 5) & $\left(1^{\mathrm{a}}\right.$ - coluna - total 1992$) 105,115$ & 161,161 \\
\hline 53 (quadro 5) & $\begin{array}{l}\left(1^{\text {a }} \text { - coluna -\% total } 1992\right) 16,27 \\
81,10 ; 1,10 ; 50,03\end{array}$ & 10,$61 ; 52,89 ; 0,01 ; 32,62$ \\
\hline 76 & $\left(2^{\underline{0}}\right.$ parágrafo $) \gamma_{0}$ & $\gamma$ \\
\hline 76 & (expressão 10$) \gamma_{0}$ & $\gamma$ \\
\hline 77 e 78 & $\begin{array}{l}\text { ( } 3^{\mathrm{a}} \text { linha e } 2^{-\mathrm{a}} \text { linhas ) uma raiz } \\
\text { unitária }\end{array}$ & raiz unitária \\
\hline 78 & $\left(2^{\mathrm{a}}\right.$ linha) tendência & tendência quadrática \\
\hline 88 & definem matriz $H^{*}$ como $H$ & definem matriz $H^{*}$ como $H$ aumentada \\
\hline 101 & (tabela 3 última linha) I nas $\Delta \Delta Y_{t}$ & III nas $\Delta \Delta \mathrm{Y}_{\mathrm{t}}$ \\
\hline 69 & Figura 12 & Figura abaixo \\
\hline
\end{tabular}

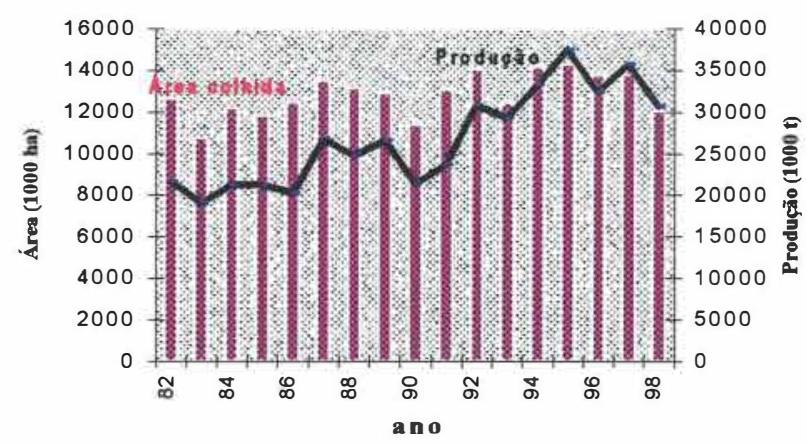

Fonte: $\mathrm{CONAB}$

Figura 12 - Evolução da área colhida e produção de milho no Brasil. 1982 a 1998. 
Dados Internacionais de Catalogação na Publicação (CIP)

DIVISÃo DE BIBLIOTECA E DOCUMENTAÇÃO - Campus "Luiz de Queiroz"/USP

\section{Costa, Silvia Maria Almeida Lima}

Liberalização comercial no Brasil e integração nos mercados de commodivies agricolas: os mercados de algodão, milho e arroz / Silvia Maria Almeida Lima

Costa. - Piracicaba, 1999.

$145 \mathrm{p}$.

Tese (doutorado) - - Escola Superior de Agricultura Luiz de Queiroz, 1999. Bibliografia.

1. Comercialização agrícola 2. Integração econômica 3. Liberalização 4. Mercado agricola 5. Mercado externo 6. Mercado interno 7. Preço agricola l. Titulo

CDD 338.14 


\section{OFEREÇO}

À meus pais. irmãos. sogra e

cunhados, pelo apoio e incentivo

DEDICO

À meu marido Valdo Fernando e à meus filhos Isabela e Paulo Vítor pelo carinho e compreensão sempre presentes 


\section{AGRADECIMENTOS}

A realização deste trabalho em grande medida foi viabilizada pela colaboração de pessoas e instituições, às quais gostaria de registrar meu reconhecimento.

À Escola Superior de Agricultura "Luiz de Queiroz" e ao Departamento de Economia, Administração e Sociologia Rural, pela oportunidade de estudar e conviver de forma salutar com os professores e funcionários.

Ao prof. Joaquim Bento de S. Ferreira Filho, pela confiança, apoio e valiosa orientação.

À prof $f^{\mathfrak{a}}$ Heloísa Lee Burnquist, com quem tive a oportunidade de conviver durante o curso de Economia Internacional e de tal convivência resultou a inspiração para este estudo.

Ao prof. Geraldo Sant' Ana de C. Barros, pelo apoio durante minha estadia (e de minha família) em Piracicaba, assim como pelas sugestões apresentadas na fase inicial da pesquisa.

Aos profs. Paulo Fernando C. de Araújo e Miriam R. P. Bacchi, pelas críticas e sugestões que contribuíram para melhoria da versão final.

Às funcionários do Departamento de Economia, Administração e Sociologia, especialmente para Luciane Cristina Cipriano, pela prontidão e disposição em auxiliar os alunos na seleção do material bibliográfico, à Maria Aparecida Maielli Travalini, Helena Aparecida Cardoso e Cristiane Cripriano pela colaboração e apoio.

À Universidade Estadual Paulista (UNESP) e a Faculdade de Engenharia de Ilha Solteira (FEIS) pela liberação de minhas atividades durante o curso de doutorado.

À CAPES, através de programa PICD, que prestou auxílio financeiro durante a realização do curso e elaboração do trabalho.

À CONAB (Companhia Nacional de Abastecimento) que tem em seu quadro técnicos muito gentis e sempre dispostos a oferecer dados e informações solicitadas.

Ao SAGYPA (Secretaria de Agricultura, Ganaderia, Pesca y Alimentación/Ministerio de Obras y Servicios Publicos da Argentina), ao Banco Central do Paraguai, pelos dados 
fornecidos e a Alfredo E. P. Picerno, do Ministério da Agricultura, Ganaderia y Pesca do Uruguai, que também se empenhou para tornar possível o envio de dados do Uruguai.

Ao Instituto Riograndense de Arroz (IRGA) e à empresa Refinações de Milho Brasil pelo fornecimentos de dados.

Ao colega Carlos Augusto Moraes e Araújo pelo valioso empenho e importante ajuda na revisão do texto.

Por fim, a meu marido Valdo Fernando que precisou usufruir da "licença maternidade" e assumir os cuidados com o lar, quando do nascimento de nosso segundo filho, oferecendo o apoio necessário para que eu continuasse normalmente as atividades do curso de doutorado. 


\section{SUMÁRIO}

Página

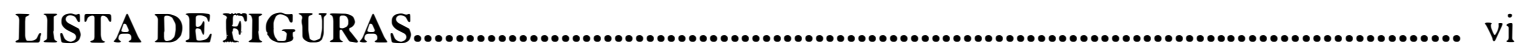

LISTA DE QUADROS .......................................................................................................... vii

LISTA DE TABELAS.................................................................................................. viii

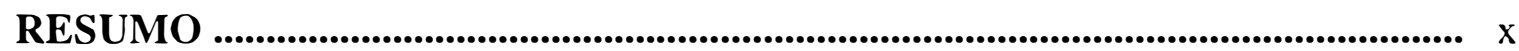

SUMMARY ............................................................................................................... xii

INTRODUÇÃO ............................................................................................. 1

1.1. Considerações gerais .................................................................................. 1

1.2. Delimitação do problema ................................................................................... 3

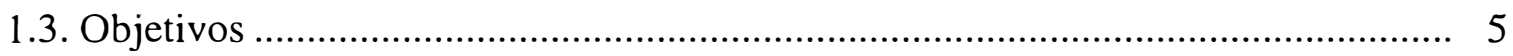

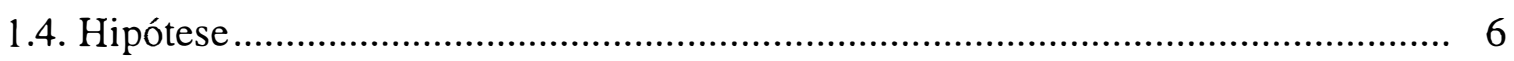

1.5. organização da pesquisa .................................................................................. 6

2. REVISÃO DE LITERATURA ..................................................................... 8

2.1. Os determinantes externos da interdependência entre mercados: a globalização das economias e os movimentos integracionistas ............................. 8

2.2. A liberalização comercial e as reestruturações nas políticas

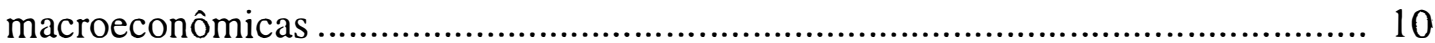

2.3. A liberalização comercial, as reformulações nos instrumentos de política agrícola e a evolução da política tarifária para a agropecuária.................. 18

2.4. Impactos sobre o setor produtivo agrícola.......................................................... 26

3. REFERENCIAL TEÓRICO ............................................................................... 33

3.1. Integração de mercados ................................................................................... 33

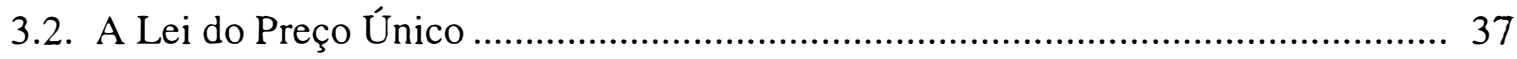

3.3. A Teoria da Paridade do Poder de Compra e a Lei do Preço Único .................... 40 
3.4. Revisão dos trabalhos que testaram a LPU

\section{CARACTERÍSTICAS DA PRODUÇÃO E DOS MERCADOS DE}

ALGODÃO ARROZ E MILHO ........................................................... 46

4.1. O mercado de algodão ....................................................................... 46

4.2. O mercado de arroz ......................................................................... 56

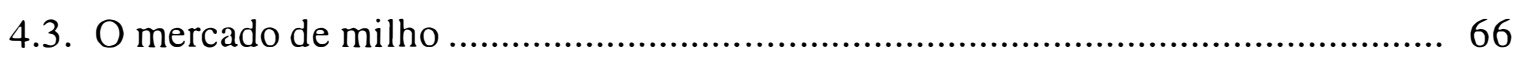

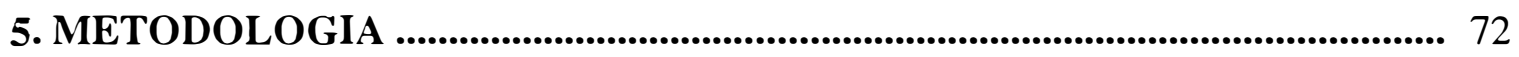

5.1. Procedimentos ................................................................................ 72

5.1.1. Estacionariedade de séries de tempo e testes de raiz unitária ........................ 72

5.1.2. Testes de raiz unitária .................................................................... 74

5.1.3 Testes de cointegração - O método de Johansen ....................................... 79

5.1 .4 Especificação dos modelos .................................................................. 86

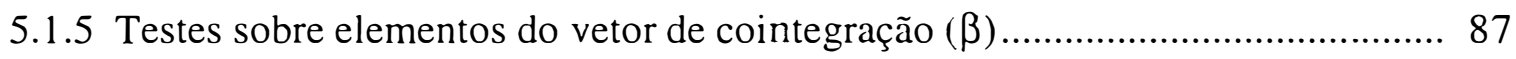

5.1.6. Teste de hipótese sobre os parâmetros alfa (testes de exogeneidade

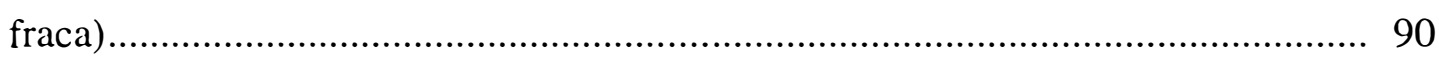

5.2. Definição dos dados utilizados ......................................................... 91

6. RESULTADOS E DISCUSSÃO ....................................................................... 96

6.1. Testes de raiz unitária ........................................................................ 96

6.1.1. Testes de raiz unitária para séries de algodão........................................... 97

6.1.2. Testes de raiz unitária para séries de milho .......................................... 100

6.1.3. Testes de raiz unitária para séries de arroz ........................................... 102

6.2. Especificação dos modelos ................................................................ 103

6.3. Testes de cointegração .................................................................... 108

6.4 Teste sobre os parâmetros $\beta$................................................................ 115

6.5. Teste sobre os parâmetros $\alpha$................................................................ 123

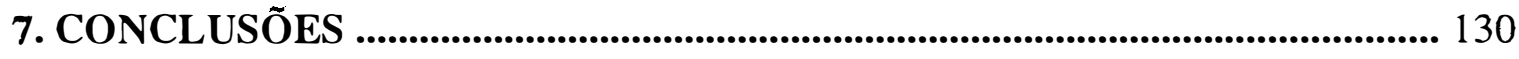

8. REFERÊNCIAS BIBLIOGRÁFICAS ............................................................... 135

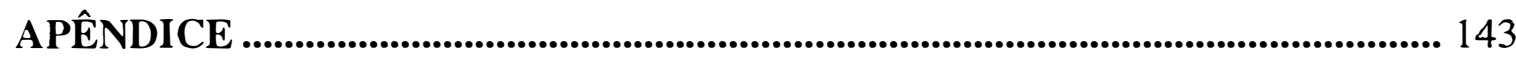




\section{LISTA DE FIGURAS}

Página

1. Evolução dos Índices da taxa de câmbio real (R\$/US\$), 1989-97 ......................... 16

2. Evolução da área e produção de grãos. Brasil 1981/82 a 1996/97 ......................... 28

3. Modelo de equilíbrio espacial ......................................................................... 35

4. Área plantada e produção de algodão em pluma no Brasil (1982-96) ..................... 49

5. Evolução das produtividades de algodão em pluma média mundial, Brasil (média nacional e região Centro-Sul), China, Estados Unidos,

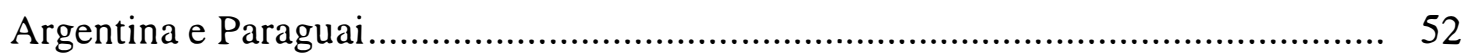

6. Evolução dos preços de algodão em pluma: Índice B, Índice A (19901998), Paraguai e Argentina (1997-98)

7. Preços de arroz ( $\mathrm{R} \$ / 30 \mathrm{~kg}$ ): Brasil, mercados:Argentina, Tailândia, Uruguai, 1990 - 1998

8. Evolução das produtividades de arroz: Brasil (média nacional e Estado do Rio Grande do Sul), Argentina e Uruguai 1985-1998 ..................................... 61

9. Evolução da área e produtividade de arroz no Brasil, 1982-1998 ............................ 63

10. Evolução das produtividades de arroz: no Estado do Rio Grande do Sul, $1982-1998$

11. Evolução das produtividades de milho: Estados Unidos, Paraguai, Argentina e Brasil (média do país e região Centro-Sul), 1986 a 1996

12. Evolução da área colhida e produção de milho no Brasil, 1982-1998

13. Evolução dos preços de milho: Brasil, Chicago (futuro, primeira entrega), Estados Unidos, Argentina e Paraguai, 1990 - 1998 


\section{LISTA DE QUADROS}

Página

1. Comparação entre as tarifas vigentes em 1987 e as aprovadas nas revisões tarifárias de 1988 e $1989(\mathrm{em} \%)$...................................................... 13

2. As reduções tarifárias de 1990 e 1994 ............................................................... 14

3. Alíquotas da Tarifa Aduaneira Brasileira de produtos Têsteis de

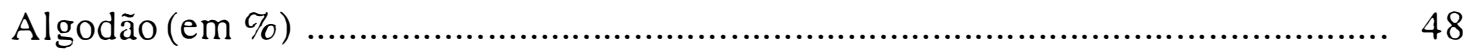

4. Quadro de suprimento anual de algodão em pluma (mil toneladas) ....................... 50

5. Importações brasileiras de algodão por país de origem (1.000t) ............................ 53

6. Alíquotas da Tarifa Aduaneira Brasileira para importação de arroz (em $\%)$

7. Importações brasileiras de arroz (branqueado) por país de origem

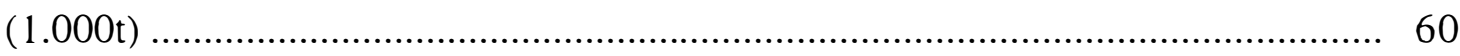

8. Quadro de suprimento anual de arroz em casca (mil toneladas) ............................ 65

9. Quadro de suprimento anual de milho em grãos (mil toneladas) ............................ 70

10. Importações brasileiras de milho por país de origem (1.000t) e participação de cada fornecedor sobre o total importado (\%) ............................... 70

11. Seqüência para os testes de raiz unitária DFA ................................................... 77

12. Características e fontes dos dados utilizados...................................................... 95 


\section{LISTA DE TABELAS}

Página

1. Testes de raiz unitária (Dickey-Fuller Aumentado) para as séries de algodão, 1994/01-1997/12

2. Testes de raiz unitária (Dickey-Fuller Aumentado) para as séries de algodão, 1990/01-1998/06.

3. Resultados dos testes de raiz unitária para as séries de milho, 1990/011998/06

4. Resultados dos testes de raiz unitária para as séries de arroz, 1990/011998/06 103

5. Testes sobre a correta especificação do modelo proposto para as séries de milho ( 3 defasagens) 106

6. Testes sobre a correta especificação do modelo para as séries de arroz (12 defasagens e 11 dummies sazonais) 106

7. Testes sobre a correta especificação do modelo proposto para as séries de algodão 1994/98 (6 defasagens) 107

8. Testes sobre a correta especificação do modelo VAR para as séries de algodão 1990/98 (2 defasagens, 11 dummies sazonais)

9. Teste de cointegração para as séries de milho 109

10. Teste de cointegração para as séries de arroz 110

11. Teste de cointegração para as séries de algodão (1994/97) 110

12. Teste de cointegração para as séries de algodão (1990/98) 
Página

13. Vetor de cointegração $(\beta)$, coeficientes de ajustamento $(\alpha)$ e a matriz

П . Séries de milho 1990/98

14. Vetor de cointegração $(\beta)$, coeficientes de ajustamento $(\alpha)$ e a matriz

П . Séries de arroz 1990/98

15. Vetor de cointegração $(\beta)$, coeficientes de ajustamento $(\alpha)$ e a matriz П . Séries de algodão 1994/97

16. Teste sobre a significância dos parâmetros $\beta$ e perfeita integração entre os pares de mercados. Séries de algodão 1994/97

17. Teste sobre a significância dos parâmetros $\beta$ e perfeita integração entre os pares de mercados. Séries de milho 1990/98

18. Teste sobre a significância dos parâmetros $\beta$ e perfeita integração entre os pares de mercados. Séries de arroz 1990/98

19. Teste sobre a significância dos parâmetros $\alpha$. Séries de algodão 1994/97

20. Teste sobre a significância dos parâmetros $\alpha$ (teste de exogeneidade).

Séries de milho 1990/98

21. Teste sobre a significância dos parâmetros $\alpha$ (teste de exogeneidade).

Modelo para as séries de arroz 1990/98 


\title{
LIBERALIZAÇÃO COMERCIAL NO BRASIL E INTEGRAÇÃO NOS MERCADOS DE COMMODITIES AGRÍCOLAS: OS MERCADOS DE ALGODÃO, MILHO E ARROZ
}

\author{
Autora: SÍLVIA MARIA ALMEIDA LIMA COSTA \\ Oientador: Prof. Dr. JOAQUM BENTO DE SOUZA FERREIRA FILHO
}

\section{RESUMO}

O objetivo deste estudo consiste em analisar se os fenômenos de globalização e liberalização comercial, assim como as mudanças nas políticas setoriais brasileiras, favoreceram a configuração de relações de integração entre mercados internos e externos das commodities algodão, milho e arroz. Tais relações de integração podem ser entendidas como relações de equilíbrio de longo prazo entre preços nos mercados. Segundo o postulado da Lei do Preço Único, as ações de arbitragem de preços de commodities nos mercados internacionais permitirão que preços em mercados espacialmente separados sejam equalizados, uma vez ajustados pela taxa de câmbio e custos de transporte. Testes de cointegração multivariados e bivariado desenvolvidos por Johansen foram utilizados para avaliar o equilíbrio de longo prazo entre preços. Também foram testadas hipóteses que decompõem as relações de longo prazo em termos do grau no qual variáveis cointegradas interagem e da velocidade de reação das variáveis. Para os mercados de algodão, os resultados não permitiram indicar integração entre preços no mercado brasileiro e no mercado de Liverpool (Índice B). Para os mercados de arroz e milho, equilíbrio de longo prazo entre os preços foram encontrados, embora não o suficiente para caracterizar que os mercados sejam integrados. Por outro lado, os testes de hipóteses permitiram indicar relações de integração entre preços brasileiros e uruguaios no mercados de arroz. Para 
os mercados de milho, os mesmos testes indicaram relações de integração entre os mercados exportadores da Argentina e Roterdã. 


\title{
BRAZILIAN TRADE LIBERALIZATON AND INTEGRATION IN AGRICULTURAL COMMODITIES MARKETS: THE COTTON, CORN AND RICE MARKETS.
}

\author{
Author: SÍLVIA MARIA ALMEIDA LIMA COSTA \\ Adviser: Prof. Dr. JOAQUIM BENTO DE SOUZA FERREIRA FILHO
}

\section{SUMMARY}

The objective of this study is to analyze whether the globalization and commercial liberalization process, as well as the changes in brazilian setorial policies, have favored integration relationships among internal and external prices of cotton, corn and rice. This integration can be understood as a long-run equilibrium relationship among prices. According to the postulate of the Law of One Price, that efficient trade and arbitrage activities will ensure that prices in spatially separated markets, once adjusted for exchange rates and transportation costs, will be equalized. The multivariate and bivariate cointegration testing procedures developed by Johansen were used to evaluate long-run equilibrium among prices. Hypothesis tests for decomposing long-run relationships in terms of the degree in which related variables interact and speed with which related variables react were also carried out. For cotton markets the results didn't allow to indicate integration between prices in the brazilian and Liverpool (B Índex) markets. For rice and corn markets, long run equilibrium among prices has been found, although integration between markets is not strong enough. On the other hand, the hypothesis tests indicate relationship of 
integrated markets for brazilian and Uruguay rice prices. For corn markets, the same tests indicated relations of integration between export markets in Argentina and United States (CIF Roterdã). 


\section{INTRODUÇÃO}

\subsection{Considerações gerais}

Até o início da década de 80 eram comuns referências à agricultura brasileira como sendo um setor caracterizado pela existência de dois subsetores, do ponto de vista da formação de seus preços. Um primeiro designado como composto de produtos exportáveis (ou bens comercializáveis externamente) e outro subsetor composto de produtos voltados para o abastecimento interno ${ }^{1}$.

Tal segmentação fundamentava-se na distinção se um dado produto estava ou não exposto às forças econômicas advindas do mercado internacional. Para o primeiro grupo de produtos, concebia-se que os preços internos seguiam de perto as mudanças nos preços internacionais e na taxa de câmbio. Para o outro subsetor, admitia-se que os mercados de produtos funcionavam como uma economia fechada (setor doméstico); as transações internacionais não eram feitas livremente e portanto, o comportamento dos seus preços não guardava uma relação direta com o comportamento dos preços internacionais, sendo apenas as variáveis econômicas internas relevantes no processo de determinação dos preços no curto prazo.

Para este último grupo de produtos agrícolas, tal evolução diferenciada dos preços internos justificava-se, do ponto de vista das políticas macroeconômicas, principalmente pela atuação de instrumentos da política comercial tais como tarifas, licenças para importação e barreiras não-tarifárias (proibições para importação, entre outras).

\footnotetext{
' Principais autores que defendiam tal configuração: Barros e Graham (1978), Homem de Melo (1981).
} 
Além da atuação dos instrumentos de política macroeconômica, o Brasil dispunha de uma política agrícola considerada fortemente intervencionista. Seus principais instrumentos eram: os preços mínimos fixados muitas vezes acima das paridades de preços internacionais; uma política de abastecimento com estoques públicos e empresas atuantes, e uma política de crédito subsidiado com base em recursos públicos.

Entretanto, a partir de meados dos anos 80, aquela configuração segmentada dos mercados agrícolas nacionais gradualmente perde relevância, de maneira que atualmente não faz mais sentido pensar-se que a formação de preços dos produtos de consumo doméstico depende apenas de variáveis internas à economia do país.

Tal transformação é entendida como decorrência das amplas reformas nas políticas macroeconômicas e setoriais empreendidas pelo Brasil, com vistas a abrir seus mercados à competitividade externa e tornar-se apto a participar da nova ordem mundial, em que os fenômenos da globalização e formação de blocos econômicos regionais passaram a determinar as relações comerciais entre os países.

Internamente, a origem das mudanças é remetida ao esgotamento do padrão de financiamento da economia no início dos ano 80, seguindo-se de amplo processo de desregulamentação dos mercados agrícolas, o qual consistiu na redução do grau de intervenção das políticas aplicadas com vistas a fazer a transição de uma etapa de grande intervencionismo estatal para outra mais voltada para os sinais de mercado.

As reformas atingiram o setor de gastos públicos na agricultura, reduzindo em muito o alcance do programa de crédito rural oficial, propiciaram a extinção dos institutos de comercialização e desativaram grande parte das políticas de sustentação de preços no mercado bem como as intervenções do governo nos mercados de estoques de produtos agrícolas.

Tal conjugação de mudanças - decorrentes dos condicionantes externos bem como das políticas internas - tem caracterizado o novo contexto no qual operam o governo e no qual os agentes econômicos tomam decisões de produção e comercialização. 
Os fenômenos da globalização e integração econômica no âmbito do Mercosul, a liberalização comercial e a redução no alcance das políticas agrícolas, propiciaram alterações qualitativas importantes no ambiente econômico em que operam os agentes, envolvendo reduções nos custos do comércio e portanto, potencializando reduções nos custos de arbitragem entre os países ${ }^{2}$, fazendo com que os vetores de preços externos sirvam de referência para a formação dos preços internamente.

A argumentação apresentada por Cavalcanti (1997) ilustra com bastante propriedade como as mudanças qualitativas alteram o espectro de variáveis a serem consideradas pelos agentes econômicos:

"(...) as decisões estratégicas das firmas passam a ser referidas em níveis globais das variáveis relevantes, e não mais em níveis distintos estabelecidos independentemente para cada mercado, refletindo sua nova percepção do contexto em que operam. A principal mudança nos padrões de comportamento das firmas reside no fato de que elas perdem a capacidade de discriminar preços entre os diferentes mercados, sendo compelidas a cobrar o mesmo preço em todos eles (...)" (Cavalcanti, 1997, p.14).

Ou seja, com a liberalização do comércio, a evolução dos preços internacionais que antes, em face da economia fechada (pelo lado das importações) pouco afetava a economia dos preços internos, revela-se agora, na economia mais aberta às importações, importante para a formação dos preços internos e da própria renda setorial.

\subsection{Delimitação do problema}

A abertura comercial, envolvendo reduções nas tarifas de importação e extinção de barreiras não-tarifárias, juntamente com as demais reformas nas políticas

\footnotetext{
${ }^{2}$ Especificamente no que diz respeito à política comercial, tais reduçōes nos obstáculos à arbitragem não foi completa (permaneceu a proteção tarifária aos insumos), nem contínua (em 1995 houve um retrocesso no processo de liberalização comercial, representado por aumentos nas tarifas de importação), como será visto.
} 
macro e setoriais, ampliaram as oportunidades de negócios e favoreceram notável crescimento do comércio internacional brasileiro em geral e de produtos agrícolas em particular ${ }^{3}$

Com tal conjugação de reformas, sobreveio significativo crescimento das importações de produtos agrícolas de consumo doméstico ou de produtos em que o país antes era exportador eventual. No caso especial de algumas commodities agrícolas (como algodão, arroz e milho), o país passa de uma posição de auto-suficiência no abastecimento interno para importador regular .

Freqüentemente argumenta-se que a ampliação da concorrência externa teria contribuído para desencadear uma crise no setor. O crescimento do volume importado estaria afetando sobremaneira a formação dos preços e renda internos, favorecendo quedas nos preços domésticos e atuando como mecanismo indutor de reestruturações no sistema produtivo. Tal fenômeno seria especialmente observado nos mercados de produtos agrícolas antes tradicionalmente exportados, como no caso do algodão, e alguns mercados de produtos tipicamente voltados para o abastecimento interno, como arroz e milho.

Esta pesquisa pretende responder a seguinte pergunta implícita: o conjunto de reformas que afetaram os mercados de produtos agrícolas nesta década (compreendendo as reformas com vistas à desregulamentação dos mercados e à abertura comercial propriamente dita) teria proporcionado maior convergência dos preços externos e internos de forma que o padrão de evolução destes últimos acompanha o padrão dos primeiros e que portanto, para cada commodity, os mercados analisados constituem mercados integrados?

No trabalho, serão apresentados alguns argumentos que induzem a acreditar em uma evolução mais próxima dos preços internos e externos das commodities agrícolas, tais como:

1. Todo o conjunto de ações que resultam na liberalização comercial e na implementação do Mercosul (Mercado Comum do Sul);

\footnotetext{
${ }^{3}$ Santo e Severo (1997) apresentam uma discussão sobre a contribuição do setor agroindustrial para o equilibrio das contas externas entre 1990/96.
} 
2. A desestatização da comercialização das safras, através, entre outros e principalmente, da reformulação dos instrumentos de política setorial;

3. A presença de financiamentos externos às importações;

4. O processo de acomodação dos sistemas produtivos de algumas culturas à maior abertura da economia, com perda de vantagens absolutas e comparativas;

5. A relativa menor necessidade ou viabilidade de formação e carregamento de elevados volumes de estoques de commodities para abastecimento interno, e

6. A presença de problemas de infra-estrutura e de logística dificultando o transporte e escoamento dos produtos entre mercados regionais nacionais.

\subsection{Objetivos}

O presente trabalho procura inquirir em que medida os preços internos e externos de algumas commodities agrícolas têm apresentado um comportamento comum de longo prazo. em mercados mundiais nos quais o Brasil tem participado na última década como importador líquido ou exportador eventual.

Especificamente pretende-se analisar se as evoluções conjuntas dos preços internos e externos das commodities algodão, arroz e milho apresentam comportamento de tal forma que os mercados envolvidos possam ser caracterizados como mercados integrados espacialmente.

Um estudo alicerçado na abordagem como a que se propõe desenvolver, pode oferecer as seguintes contribuições:

a) no fornecimento de indicações sobre em que medida os mercados internos e externos das commodities abordadas podem ser considerados mercados integrados; 
b) a verificação empírica sobre se mercados internos e externos encontram-se integrados, pode lançar alguma luz sobre uma questão muito comentada atualmente: períodos de escassez de mercado, resultantes da produção de safras curtas, não mais são seguidos por períodos de elevação dos preços internos (para produtos que têm mercado externo); na vigência de tarifas de importação muito baixas ou nulas, o mercado externo provê o abastecimento do mercado interno e as importações garantem que os preços internos se equalizem ao nível dos preços no mercado internacional.

\subsection{Hipótese}

Nesta década, o caráter transnacional de algumas das grandes empresas que operam no setor de grãos e fibras, a redução das barreiras ao comércio de commodities agrícolas (internas e externas) e a melhor qualidade e disponibilidade de informações mercadológicas colocadas à disposição dos agentes econômicos, favorecem a configuração de relações de integração entre os mercados brasileiros e entre aqueles com os quais este mantém relações comerciais.

\subsection{Organização da pesquisa}

O período estudado é 1990/98 sendo que as análises para o caso do algodão foram segmentadas em dois períodos (1990/97 e 1994/97).

O trabalho está organizado em 8 capítulos, incluindo este. No capítulo 2 encontra-se uma revisão de literatura onde se apresenta a evolução do processo de liberalização comercial, incluindo uma revisão dos principais pontos abordados nas reformas nas políticas comerciais levadas a efeito entre os anos 80 e 90. Ainda no mesmo capítulo discutem-se os impactos gerais sobre o setor agrícola, do conjunto de reformas envolvidas no processo de liberalização comercial e a questão do crescimento das importações agrícolas. 
O capítulo 3 apresenta o referencial teórico e compreende uma revisão específica sobre os fatores que influem na existência e no grau de integração de mercados e a "Lei do Preço Único".

No capítulo 4 são abordados alguns aspectos dos sistemas produtivos e de mercados das commodites estudadas. O capítulo 5 descreve a metodologia utilizada na investigação empírica sobre integração de mercados, além de apresentar os dados utilizados e, no capítulo 6 , encontram-se todos os resultados da pesquisa.

Por fim. nos capítulos 7 e 8 estão respectivamente, as principais conclusões da pesquisa e as referências bibliográficas. 


\section{REVISÃO DE LITERATURA}

Nos anos noventa, embora as condições para a integração dos mercados não tenham sido as ideais no que se refere ao ambiente institucional que governa as relaçōes comerciais entre nações, uma conjunção de fatores presentes ao longo da década (alguns estruturais outros contingenciais) atuou no sentido de tornar os preços dos mercados de commodities agrícolas interrelacionados.

Desta forma, na esfera internacional destacam-se a globalização das economias, os movimentos integracionistas e a disponibilidade de financiamento externo para importações. No âmbito interno, por outro lado, destacam-se as reformas levadas a efeito na política comercial, a desregulamentação das políticas setoriais, a política cambial e as questões associadas à competitividade e vantagens comparativas do setor produtivo, as quais são sumariamente discutidas a seguir.

Este capítulo não esgota toda a revisão de literatura. O capítulo sobre referencial teórico contemplará uma revisão específica sobre integração de mercados e a Lei do Preço Único.

\subsection{Os determinantes externos da interdependência entre mercados: a globalização das economias e os movimentos integracionistas}

$\mathrm{Na}$ presente década, a globalização econômica tem sido associada a um novo modelo de desenvolvimento econômico mundial, cujos pressupostos contrariam aquele vigente por várias décadas anteriores, o qual baseava-se na proteção efetiva à indústria nacional. Desta forma, a globalização está associada à crescente redução nos 
entraves à circulação de bens, serviços e recursos financeiros. $\mathrm{O}$ aumento na frequiência das transações comerciais, dos investimentos estrangeiros diretos e dos fluxos financeiros é suficiente para explicar a maior interdependência entre nações distintas.

Para Montoya (1998), apesar da inserção dos países num mundo globalizado não ser igualitária e existir um componente discriminatório em relação aos países em desenvolvimento, tal fenômeno acaba por induzir cada nação a rever seus instrumentos de proteção e abrir-se ao comércio externo.

Da mesma forma, os movimentos de integração regionais, observados na primeira metade da década com a consolidação dos acordos do Nafta (que cria uma área de livre comércio entre o México, EUA e o Canadá a partir de 1994), e o Mercosul ${ }^{4}$ (união aduaneira entre Brasil, Argentina, Uruguai e Paraguai criado em 1995, incluindo Bolívia e Chile em 1996) também objetivaram a inserção competitiva das regiões nos mercados mundiais, definindo-se um espaço econômico para tornar possível, via fluxos de comércio, o aproveitamento das vantagens comparativas e das economias de escala que um mercado ampliado permite.

Tais integrações regionais iniciaram-se com a implementação de mecanismos destinados a eliminar a discriminação intra-regional, enquanto se estabeleceram tarifas externas comuns contra terceiros países.

A entrada em vigor do Mercosul, a partir de $1^{0}$ de janeiro de 1995 , colocou fim a um período de transição, durante o qual prevalecia ainda uma série de restrições quantitativas e outros instrumentos de proteção não tarifária, como também implementou uma união aduaneira imperfeita, tornando livre cerca de $85 \%$ das mercadorias e introduzindo a Tarifa Externa Comum (TEC) .

Aponta-se entretanto, que entre a assinatura do referido tratado e o início da vigência do Mercosul, ocorreu um significativo incremento do comércio na região, o que é explicado por esforços de abertura do comércio tanto unilateral e abrangente quanto através de uma desgravação tarifária progressiva acordada entre os

\footnotetext{
${ }^{4}$ Nafta (Acordo de Livre Comércio Norte Americano), Mercosul (Mercado Comum do Sul).
} 
países membros. No período 1990/95, o comércio intra-Mercosul teria crescido cerca de $240 \%$, enquanto as exportações extra-Mercosul apenas se expandiram $48 \%$ aproximadamente (Waddington e Braz, 1996).

Um outro determinante externo indutor de mudanças nas políticas macro e setoriais, refere-se ao encerramento da Rodada Uruguai do GATT ${ }^{5}$ em 1993, que determinou o corte de subsídios à produção agrícola, como forma de reduzir as distorções do comércio internacional.

\subsection{A liberalização comercial e as reestruturações nas políticas macroeconômicas}

Até o início dos anos 80 , as políticas macroeconômicas e setoriais foram moldadas, muitas vezes, para conduzir os mercados agropecuários de forma diferenciada da tendência observada no mercado internacional, atendendo a um modelo de crescimento calcado na lógica de substituição de importações, o qual passou a apresentar sinais de esgotamento já no início daquela década. A permanência dos pressupostos deste modelo potencialmente faria aquelas políticas colidirem com os princípios da nova filosofia geral do comércio mundial que é a de usar as forças de mercado para induzir a modernização e reestruturação dos setores.

Neste contexto, e em sentido amplo, a liberalização comercial está associada a uma série de mudanças levadas a efeito nas políticas macroeconômicas (com ênfase nas políticas comercial e cambial), nas políticas setoriais, bem como a reestruturações nos mercados de produtos agropecuários, com vistas a substituir o protecionismo por maior liberdade de mercado. Neste sentido, buscou-se reduzir os gastos públicos e promover um afastamento do setor governamental no processo de formação de preços. tornando assim o ambiente mais propício para a realização de trocas.

No que se refere às políticas macroeconômicas internas, são as reformas da política comercial aquelas mais comumente associadas ao processo de 
liberalização comercial ${ }^{6}$. Neste contexto, a seguir procura-se apresentar uma revisão da evolução da política comercial em geral e da política comercial voltada para produtos agrícolas em particular.

Para Kume (1996), o conceito usual de liberalização comercial diz respeito à redução do nível (média e mediana) e variação (amplitude e desvio padrão) do grau de proteção às atividades competitivas por importação.

Pode-se dizer que, a partir de meados da década de 80 , as mudanças desencadeadas na política comercial passaram por cinco importantes fases, as quais podem ser delimitadas pela seguinte divisão cronológica: 1988 (início do processo de reduções tarifárias,.com queda no nível médio das tarifas); 1990-93 (aprofundamento do processo de liberalização comercial com o cumprimento de um cronograma de reduções tarifárias previamente estabelecido); 1994 (em função da forte valorização cambial, da acentuada entrada de capitais externos e a ocorrência de intenso crescimento das importações globais. ocorre intensificação do processo de abertura comercial através de reduções tarifárias com vistas a garantir o sucesso do programa de estabilização de preços), e 1995 (retrocesso do processo de abertura comercial com aumento nas alíquotas de importação para alguns produtos em resposta ao surgimento de déficits e da crise mexicana no final de 1994, responsável pela fuga de capitais externos dos países emergentes) e retomada de pressões protecionistas por segmentos produtivos.

Os pontos mais importantes de cada uma das reformas são brevemente apresentados a seguir.

\footnotetext{
${ }^{5}$ GATT (Acordo Geral de Tarifas e Comércio)
} 


\section{- As reformas de 1988 e 1989}

Segundo Lemme (1989), até meados dos anos 80, a estrutura tarifária brasileira encontrava-se bastante defasada, pois a Tarifa Aduaneira do Brasil preservava grande parte da estrutura tarifária de 1957. Como decorrência desta distorção, criou-se a necessidade de desenvolver extenso rol de regimes especiais de tributação, visando a redução do custo de aquisição de bens no mercado externo que se destinassem a setores considerados prioritários, e de se levantar uma série de barreiras não-tarifárias, com o intuito de resguardar os diversos setores de possíveis concorrências consideradas desleais.

Em 1986, a então Comissão de Política Aduaneira (CPA) iniciou uma primeira revisão ampla da Tarifa Aduaneira do Brasil (TAB), cujos resultados passaram a vigorar em junho de 1988. É a esta data que normalmente se faz referência ao início do processo da abertura comercial brasileira, ${ }^{7}$ consubstanciado por três medidas básicas: $(i)$ redução generalizada no nível médio das tarifas aduaneiras ${ }^{8}$; (ii) extinção do Imposto de Operação Financeiras e da Taxa de Melhoramento dos Portos (que teriam sido incorporados no imposto de importação), e (iii) redução no espectro de produtos para os quais encontravia-se suspensa a emissão de guias de importação (Anexo C - CACEX).

Esta primeira etapa da reforma, embora tenha produzido uma estrutura tarifária com menor dispersão e menor nível médio de alíquotas, se comparada com a TAB anterior, não teria esgotado o processo de revisão tarifária, [Lemme (1989)]. Alguns setores permaneceram com proteção excessiva, deixando margens para reduções tarifárias posteriores. Outros, como o setor química, permaneceram com a chamada alíquota promocional, que diz respeito à manutenção de uma alíquota mais elevada para produtos sem produção nacional, com o objetivo de estimular a nacionalização destes produtos.

\footnotetext{
${ }^{6}$ Embora esta política precise estar conjugada às mudanças na política cambial, cujo desempenho será abordado adiante.

${ }^{7}$ Kume (1995) por exemplo, considera esta data como o início do processo de abertura comercial.
} 
Nesta primeira reforma, assim como nas reformas subseqüentes, foi utilizada a noção de complexo industrial. Tal conceito tornou-se relevante por conseguir refletir de forma adequada a estrutura industrial e suas inter-relações, propiciando uma visão das várias cadeias produtivas, a partir das indústrias básicas, intermediárias e finais, explicitando as relações de compra e venda entre as mesmas (Lemme, 1989).

A segunda revisão, implementada em setembro de 1989, foi mais modesta em sua abrangência, sendo contemplados apenas alguns setores considerados estratégicos para a economia, como bens de capital e bens intermediários (microcomplexos siderúrgicos e metalurgia, setor químico e petroquímico). Como mostra o quadro 1, com as reformas tarifárias de 1988 e 1989, as tarifas médias caíram de $51 \%$ para $35 \%$ em 1989 .

\section{Quadro 1 - Comparação entre as tarifas vigentes em 1987 e as tarifas aprovadas nas revisões tarifárias de 1988 e 1989 $(\mathrm{em} \%)$}

\begin{tabular}{|rccc|}
\hline & 1987 & A partir de 06/1988 & A partir de 09/1989 \\
\hline Média & 51 & 41 & 35 \\
Moda & 30 & 40 & 40 \\
Mediana & 45 & 40 & 35 \\
Intervalo & $0-105 \%$ & $0-85 \%$ & $0-85 \%$ \\
\hline
\end{tabular}

Fonte: Lemme (1989)

\section{- As reformas de 1990 e 1991}

As reformas na política comercial dos anos noventa foram introduzidas em duas fases. A primeira fase teve lugar em março de 1990, pela qual foram eliminadas as restrições administrativas às importações, a partir do que o controle das mesmas seria realizado através da tarifa aduaneira e da taxa de câmbio. Esta reforma compreendeu, em

\footnotetext{
${ }^{8}$ Conforme Lemme (1989) e Kume (1995) tal queda das tarifas aduaneiras teria atingido principalmente a parcela redundante das mesmas, entendendo-se por parte redudante de uma tarifa a diferença entre o preço
} 
seus componentes principais, estes ítens (Revista Brasileira de Comércio Exterior, 1992):

1. eliminação de vários regimes especiais de importação, embora não tenha afetado alguns dos mais importantes (como as importações relacionadas com a Zona Franca de Manaus);

2. eliminação de restrições quantitativas para importações pela CACEX, incluindo a lista de produtos de importação proibida, composta primordialmente por bens de consumo, cujas tarifas foram aumentadas;

3. eliminação de incentivos fiscais;

4. instituição de um sistema de taxas de câmbio flutuantes, e

5. remoção da exigência de financiamento externo imposto sobre as importações de bens de capital e de grande valor.

A segunda fase da reforma, iniciada em 1991, refere-se à programação de reduções da tarifa média e sua variação inter-setorial, com cronograma para o cumprimento das reduções tarifárias previsto para se estender até 1994. A extensão das reformas tarifárias pode ser visualizada na tabela abaixo:

\section{Quadro 2 - Reduções Tarifárias entre 1990 e 1994}

\begin{tabular}{|lccccc|}
\hline & 1990 & 1991 & 1992 & 1993 & 1994 \\
\hline Média & 32,2 & 25,3 & 21,2 & 21,2 & 14,2 \\
Moda & 40,0 & 20,0 & 20,0 & 20,0 & 20,0 \\
Desvio Padrão & 19,6 & 17,4 & 14,2 & 10,7 & 7,9 \\
\hline
\end{tabular}

Fonte: RBCE, fev. 1992, p. 41 (a partir de dados da Coordenaçāo Técnica de Tarifas, Ministério da Economia)

A estrutura tarifária foi definida para o atendimento dos seguintes critérios básicos:

1. alíquota de $0 \%$ - produtos sem produção nacional (exemplo bacalhau); produtos com nítida vantagem comparativa (predominantemente exportáveis 
como suco de laranja, castanha do pará, etc); produtos com elevada proteção natural (elevado custo de transporte internacional) e commodities com pequeno valor agregado ${ }^{9}$;

2. alíquota de 5\% - produtos que já possuíam este valor tarifário em 1990;

3. alíquota de $10 \%$ a $15 \%$ - produtos que ao longo da cadeia produtiva se utilizem de insumo básico com alíquota de 0\%;

4. alíquota de $20 \%$ - produtos manufaturados em geral (produtos agrícolas industrializados);

5. alíquota- de 30\% - produtos específicos da química fina, videocassetes, aparelhos de som; derivados de trigo (massas e biscoitos), e

6. alíquota de $40 \%$ - produtos de informática .

\section{- A política comercial após 1994, os financiamentos externos e a política cambial}

Entre 1993 e 1994, em geral a política comercial faz uso intenso de reduções tarifárias no período de transição da moeda (quando vigorou a URV) e no primeiro ano do Plano Real. A maior exposição dos mercados à competição externa, também muito facilitada pelo comportamento da política cambial, como será abordado adiante, representava um mecanismo de conter possíveis aumentos de preços internos em face do aumento da demanda que se seguiu à implementação daquele plano.

A taxa de câmbio é o preço através do qual se efetivam as transações da economia doméstica com outros países; em termos nominais, representa o preço relativo das moedas entre dois países. Em uma economia aberta às transações internacionais, o

\footnotetext{
${ }^{9}$ Apesar da instituição destes critérios, Lopes (1994) ressalta que alguns produtos agrícolas que tiveram tarifas zeradas estariam fora das qualificaçōes necessárias para produtos que receberiam tarifa zero (como os casos do algodão e do feijāo).
} 
valor de mercado da taxa de câmbio é considerado uma das variáveis mais importantes para a rentabilidade e competitividade das atividades produtivas. ${ }^{10}$

A figura 1 permite evidenciar a forte tendência de valorização da taxa de câmbio, indicando ter havido, no curto prazo, significativa perda de renda e rentabilidade na atividade agrícola no período, também chamada de "âncora verde" em termos de inflação.

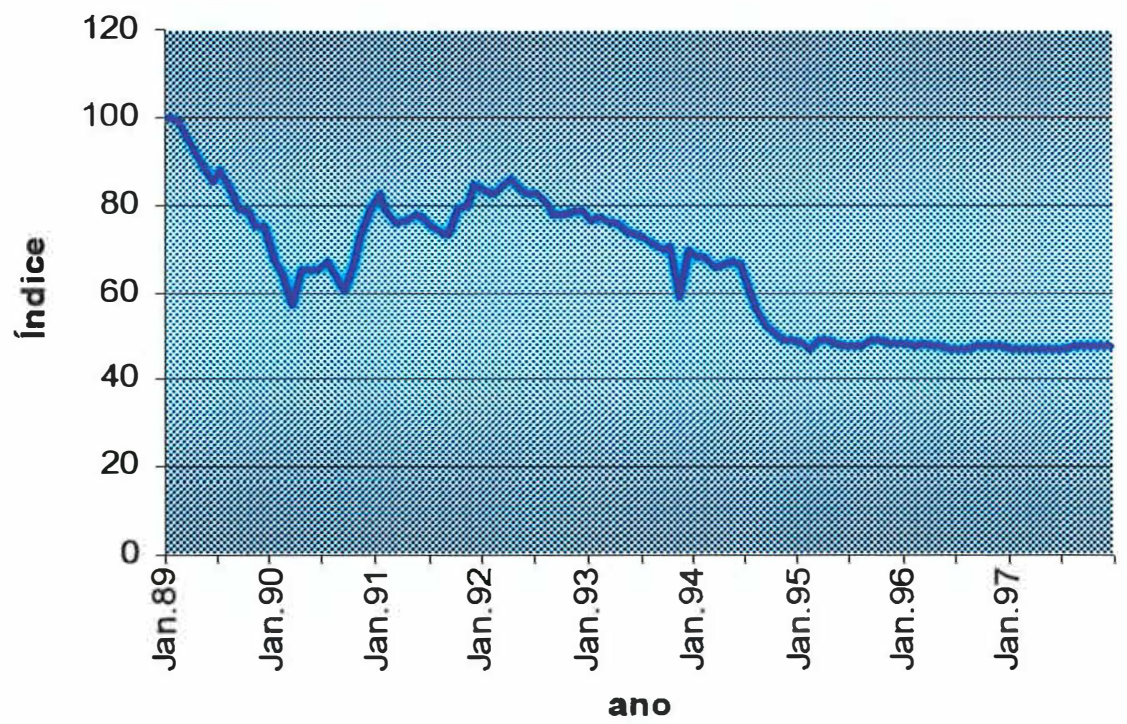

Fonte: Dados básicos da FGV.

Figura 1 - Evolução dos Índices da taxa de câmbio real (R\$/US\$), 1989-97.

De 1990 a julho de 1994, a liberalização comercial foi acompanhada de uma certa desvalorização real do câmbio, dadas as correções efetuadas em 1990 e 1992 (desvalorizações). A figura acima permite visualizar que a maior parte da valorização

\footnotetext{
${ }^{10}$ Competitividade é aqui entendida tomando-se por referência o "conceito macro", ou seja, aquele que avalia a competitividade de um país a partir de variáveis que dependem basicamente de decisões de política econômica, tais como taxa de câmbio, subsídios e incentivos à exportação e à política salarial.
} 
cambial ocorreu após a implementação do Plano Real, na magnitude de $28,5 \%$ entre junho de 1994 e dezembro de 1997.

Além da valorização do real frente ao dólar, a abertura comercial foi intensificada após a introdução do Plano Real, em função de três outros fatores simultâneos: a necessidade de impor maior disciplina aos preços domésticos dos produtos importáveis através do acirramento da competição externa que levou a reduções tarifárias: as reduções nas alíquotas do imposto de importação decorrentes da implementação da tarifa externa comum do Mercosul (com antecipação para setembro de 1994 da tarifa externa que vigoraria a partir de janeiro de 1995), e a disponibilidade de financiamentos externos às importações.

Dessa forma, as importações mensais, favorecidas pelo excepcional aumento da demanda agregada verificada após a implementação do Plano Real, tiveram grande incremento, ao que sobrevieram déficits de proporções preocupantes na balança comercial.

Como conseqüência do grande incremento das importações e como resposta à crise mexicana, às perspectivas de déficits em conta corrente e às pressões protecionistas de setores afetados pela forte concorrência estrangeira, em 1995 o governo aumentou as tarifas de importação de um grupo de produtos selecionados e retomou a utilização de restrições não tarifárias.

Os setores atingidos foram aqueles responsabilizados por acelerar o crescimento das importações, como automóveis, motocicletas, bicicletas, tratores, eletroeletrônicos de consumo, tecidos, cobertores e tênis. Paralelamente, para impedir aumentos nos preços domésticos considerados abusivos, o governo reduziu alíquotas também para um grupo de insumos. Tal aumento de tarifas, juntamente com a utilização de restrições não tarifárias, teria sido considerado um retrocesso no programa de liberalização de importações que vinha sendo gradativamente implementado desde 1988 (Kume, 1996).

A respeito da disponibilidade de financiamentos externos para as importações, o aumento da demanda por este tipo de recurso é explicado pelo elevado 
diferencial entre as taxas de juros internas e externas, o que tornou possível obter recursos externos a custo reduzido e aplicá-los no mercado doméstico a taxas mais elevadas. Ou seja, a importância destas operações estaria no fato de, para o importador, existir a possibilidade de realizar ganhos financeiros com operações de arbitragem de taxa de juros. Nas palavras de David e Nonnenberg (1996, p.229) "com o contingenciamento da política creditícia, especialmente a partir de 1994, o custo de oportunidade desses recursos passou a ser o custo de obtenção de empréstimos no mercado brasileiro, várias vezes superior ao custo externo".

A este respeito Rezende et al. (1997) analisam a evolução das importações financiadas no período 1990/96 e as vinculações destas com as arbitragens de taxas de juros, internas e externas. O trabalho conclui que, embora relevantes, não se atribui o principal fator de incentivo ao aumento das importações, à presença do financiamento. As principais fontes de incentivos para tanto, segundo os autores, estariam na abertura comercial em si, com eliminação de barreiras tarifárias e nãotarifárias.

\subsection{A liberalização comercial, as reformulações nos instrumentos de política agrícola e a evolução da política tarifária para a agropecuária}

Em termos setoriais, a liberalização comercial no Brasil esteve associada à promoção de uma ampla desregulamentação dos mercados agropecuários com vistas a reduzir o grau de intervenção do governo nos seus mercados. Nesta estiveram incluídas revisão em várias formas de legislação, programas, políticas e extinção de alguns institutos de comercialização ${ }^{11}$. Tal busca de maior realismo de mercado deu-se em função tanto de dificuldades internas, inerentes às próprias políticas como também em função de determinantes externos.

\footnotetext{
${ }^{11}$ Uma análise pormenorizada deste processo de desregulamentação encontra-se em Lopes (1996b).
} 
No que se refere às dificuldades internas, as críticas apontavam ineficiências com relação à administração das políticas setoriais, tais como liberação extemporânea de recursos, a não disponibilidade de recursos em tempo hábil e aquém das necessidades, e questionamentos quanto ao aspecto distributivo (a concessão de subsídios, através do crédito rural, cujo principal objetivo seria promover maior eqüidade, ao invés de reduzir as desigualdades, teria provocado maior concentração de renda).

Além destes desvios de eficácia, sobreveio a constatação de que as despesas associadas às políticas setoriais estariam provocando impactos negativos e insustentáveis nos orçamento fiscal. Em especial as políticas de crédito rural e de preços mínimos tiveram seus espaços de atuação reduzidos, com significativos cortes nos orçamentos fiscais associados às mesmas.

A estratégia adotada para corrigir as distorções consistiu em reduzir os subsídios para a agricultura comercial e na criação de instrumentos alternativos (embora de alcance muito mais reduzido, relativamente às políticas de crédito e de preços mínimos) para finnanciamentos e operação nos mercados, como as Cédulas de Produto Rural $(\mathrm{CPR})^{12}$, os Contratos de Opções e o Prêmio de Escoamento de Produto (PEP). Dessa forma, o segmento produtivo da agricultura comercial passou a ter que tomar suas decisões de produção e comercialização a partir das sinalizações do mercado, enquanto os escassos recursos orçamentários oficiais passaram a ser mais direcionados para a agricultura de base familiar, através do PRONAF (Programa de Fortalecimento da Agricultura Familiar) e o PROCERA (Programa de Crédito Especial para a Reforma Agrária) de acordo com Mendonça de Barros e Miranda (1998).

As mudanças promovidas no sentido de abrir a economia ao maior intercâmbio comercial, trazem também alterações na concepção da política de garantia de preços para o setor. Nesta década, a política de estoques públicos associada à

\footnotetext{
12 Nesta fase de reestruturação da política agrícola, a captação de recursos externos também foi considerada uma fonte de liquidez importante para o complexo agroindustrial brasileiro e foi em grande parte viabilizada através da chamada "63 rural".
} 
política de garantia de preços exemplifica bem o caso de uma política setorial que fica inviabilizada nó contexto de uma economia aberta e integrada. Até os anos oitenta, a política de garantia de preços mínimos (associada à política comercial) era capaz de manter os níveis de preços internos acima daqueles vigentes no mercado internacional, e para tanto fazia uso da formação de estoques públicos através das Aquisições e Empréstimos do Governo Federal.

Com a abertura da economia, uma política de preços de garantia altos perde a capacidade de sustentação dos preços internos ao nível anunciado porque acaba estimulando a internalização de importações excessivas com também elevada formação de estoques públicos, o que de fato ocorreu em 1992 e 1994 .

Segundo Mendonça de Barros e Miranda (1998, p. 166), o ano de 1995 mostrou claramente a inviabilidade de se fazer sustentação de renda agrícola com preços mínimos acima do mercado internacional - neste ano, justamente quando os estoques de alguns produtos atingiram os mais elevados níveis (11 milhões de toneladas de milho e 5 de arroz), os preços mostraram-se sensivelmente deprimidos.

Sobre as mudanças na política comercial para o setor, Kume (1995) apresenta a evolução das reduções tarifárias para os produtos agrícolas no período compreendido entre 1988 e 1993, mostrando que a tarifa nominal média caiu de $58,7 \%$ em maio de 1988 para 36,5\% em junho do mesmo ano; seguida de reduções para 30,7\% em setembro de 1989; 30,6\% em junho de 1990 e para 12,6\% em julho de 1993. O desvio padrão também teria reduzido indicando maior homogeneidade da tarifa nominal.

Em 1995, a instituição do Mercosul impôs, entre os países membros, a definição de alíquotas alfandegárias zero no comércio dentro da comunidade, como também a necessidade de adoção de uma estrutura uniforme de barreiras tarifárias em relação ao resto do mundo (Tarifa Externa Comum).

Entretanto, esta área de livre comércio é ainda considerada uma união algandegária imperfeita, em que há grande número de exceções à tarifa externa comum, 
situação prevista para vigorar até 2006, quando deverão cessar as exceções ao livre comércio regional para setores considerados sensíveis e as tarifas em geral deverão convergir para os níveis acordados no âmbito da Tarifa Externa Comum.

\section{Quanto aos impactos das reformas na política comercial sobre o}

mercado de produtos agrícolas, pode-se observar que a literatura específica sobre a interação política comercial / desempenho dos mercados de produtos agrícolas concentra-se em alguns pontos.

Um primeiro ponto de discussão nas abordagens sobre condução da política comercial e desempenho do mercado de produtos agrícolas diz respeito à interferência da política comercial nos mercados através de intervenções governamentais com vistas à regularização do abastecimento interno. O dispositivo de reduções tarifárias era utilizado com freqüência nos anos em que uma escassez de oferta potencialmente faria aumentar os preços.

Nos anos 90, mesmo no período aprazado para o cumprimento do cronograma de reduções tarifárias (entre 1991 a 1993), alterações tarifárias abruptas teriam sido freqüentes. Kume (1995) mostra que em 1990 foram zeradas as tarifas do feijão, bovinos e carne refrigerada. O mesmo procedimento foi adotado em 1991, para os produtos: sardinha, arroz, batata, milho, cebola, carne refrigerada e trigo para uma determinada quota; em 1992. para os bens: sardinha e cevada; em 1993, a tarifa do trigo foi diminuída de $15 \%$ para $5 \%$; do alho em pó, de $20 \%$ para $10 \%$ e a farinha de trigo, de $15 \%$ para $5 \%$.

Da mesma forma, após a implantação do Plano Real também continuaram freqüentes as reduções não planejadas nas alíquotas de importação e, com um fator agravante e bastante divulgado, ocorreram reduções tarifárias em anos de safras normais e em meses de colheita da safra. Isto oportuniza maior contestabilidade dos mercados de produtos pelas importações desgravadas. Um exemplo deste tipo de viés na condução da política tarifária teria ocorrido em abril de 1995 quando foram zeradas as 
tarifas de importação do milho, carne e outros produtos. No caso do milho, tal redução tarifária ocorreu em pleno período de colheita de uma grande safra deste cereal. ${ }^{13}$

Kume (1995) lembra que, além da falta de uma proteção estável, estas modificações tarifárias, que têm como objetivo imediato apenas a alteração momentânea dos preços, acabam por provocar algumas vezes, desalinhamento na estrutura tarifária. Ou seja, proporciona o aparecimento de produtos similares com tarifas diferenciadas ou proteção efetiva negativa, em decorrência de alíquotas médias nos insumos superiores à tarifa do produto final.

Em resumo, pode-se dizer que a existência de uma estrutura tarifária desalinhada representa um obstáculo para a livre existência de mecanismos de arbitragem, pois provoca quebra de estabilidade do processo de liberalização comercial e da estrutura dos preços, segundo Kume (1995).

Um segundo ponto de discussão nas abordagens sobre a condução da política comercial e desempenho dos mercados agrícolas diz respeito à consistência entre as tarifas associadas aos produtos e aos insumos. Em geral discute-se que a tarifa nominal, a que incide diretamente sobre o produto importado, não fornece a exata medida da proteção que o produto recebe. O mais adequado é estabelecer comparações da proteção nominal com a proteção efetiva, isto é, a que leva em conta a taxação dos insumos importados, através dos indicadores taxa de proteção nominal (TPN) e taxa de proteção efetiva (TPE).

Enquanto a taxa de proteção nominal mede os níveis de proteção ${ }^{14}$ ao produto final a partir da comparação dos preços domésticos e internacionais, a taxa de proteção efetiva mede a proteção ao produto final em relação aos seus principais insumos (calculada com base no valor adicionado). Para os objetivos desta pesquisa, pretendeu-se elaborar uma revisão dos trabalhos que apontam estimativas de taxas de proteção nominal para verificar se foram percebidas alterações nos coeficientes de

\footnotetext{
${ }^{13}$ Esta questão é discutida em Lopes (1995b).

${ }^{14}$ Exemplos de formas de proteção provocadas pelas políticas agrícolas são preços mínimos e crédito rural subsidiado. No caso de formas de desproteção provocadas pela intervenção governamental pode-se citar a taxa de câmbio sobrevalorizada, altos níveis de barreiras alfandegárias e internalização de produtos com subsídios na origem.
} 
proteção (sinais e magnitudes) a partir da segunda metade da década de 80 (quando tiveram início as reestruturações nas políticas setorias e a abertura comercial).

Quando, no cálculo da taxa de proteção nominal, se utiliza a taxa de câmbio oficial na comparação dos preços internos e externos, obtém-se os efeitos diretos das políticas macroeconômicas e setoriais sobre os incentivos de preços. Quando se toma a taxa de câmbio de equilíbrio, tem-se o efeito indireto destas políticas sobre os incentivos de preços.

Se a taxa de proteção nominal, expressa em termos percentuais, for positiva, o resultado indica que o produto recebe uma proteção (ou incentivo), significando que o preço no mercado doméstico esteve acima do preço internacional trazido ao nível do segmento de mercado em que os preços foram tomados. Se for negativa, implica que se recebe, no mercado interno, uma remuneração menor do que o mercado internacional livre de distorções, ou alternativamente, que o segmento de mercado interno esteve sofrendo uma desproteção (ou proteção negativa).

Lopes (1994) afirma que as reformas com vistas à desregulamentação do mercado em geral teriam reduzido substancialmente os níveis de proteção ao setor agrícola - a taxa de proteção ponderada dos produtos agrícolas teria sofrido redução, segundo o autor, de 49,5\% em 1986 para -10,8\% em 1992.

$\mathrm{Na}$ verdade espera-se que, nesta década as reformas havidas na política comercial (reduções tarifárias e extinção de barreiras não-tarifárias) e na política cambial induzissem a uma redução nos valores absolutos das taxas de proteção nominal. Entretanto, nos trabalhos onde estas estimativas são apresentadas de forma desagregada (por produto), tal tendência não se apresenta claramente.

Burnquist (1997) calculou a taxa de proteção nominal para açúcar, soja, arroz e trigo. O trabalho aponta estimativas para os subperíodos 1988/90 e 1991/94, e mostra, para todos os produtos ${ }^{15}$, estimativas altas e negativas. Assim, pelos resultados da autora, o produtor nacional teria permanecido sofrendo uma desproteção (ou

\footnotetext{
${ }^{15}$ Tanto com câmbio nominal quanto com câmbio de equilíbrio.
} 
proteção negativa), recebendo remuneração menor do que no mercado internacional mesmo após a reforma das políticas comerciais.

Netto e Campos (1995) calcularam a taxa de proteção nominal a partir da hipótese do Brasil importar milho e soja do Mercosul para o mercado de São Paulo, no período de janeiro de 1990 a fevereiro de 1995. Verificaram que os preços dos produtos vindos da Argentina mostraram-se 29,91\% e 17,97\% maiores que os preços domésticos para soja e milho, respectivamente e a partir da taxa de câmbio oficial (taxa de proteção nominal negativa).

As mesmas estimativas, elaboradas com correção cambial, revelaram que a diferença entre preços de fronteira para aqueles produtos teria passado para $39,91 \%$ e $29,70 \%$, o que implica em aumento da competitividade dos preços domésticos. Dessa forma, a defasagem cambial estaria tributando o setor em $10 \%$ e $11,73 \%$ (diferença entre as taxas de proteção nominal e as taxas de proteção nominal líquida para milho e soja, respectivamente), representando, segundo os autores, ônus à produção doméstica, na medida em que favorece a internalização do produto importado, com efeito depressor sobre os preços recebidos pelos produtores.

A taxa de proteção efetiva mede a relação entre a proteção (ou desproteção) contida no produto final e a contida nos principais insumos que entram na produção do bem, estes últimos gravados com tarifas alfandegárias. Pode também ser calculada com impostos (nos produtos e insumos) e com ou sem correção cambial.

Santos (1998) apresenta estimativas anuais de taxa de proteção nominal e efetiva para o Estado do Paraná (1985 a 1996) para várias culturas. Os resultados confirmaram não haver uma tendência clara de mudança nas magnitudes das taxas de proteção em função das mudanças introduzidas nas políticas setoriais e da abertura comercial. Mesmo para culturas tipicamente de exportação (como soja) ou tipicamente de consumo interno (como arroz), as estimativas do trabalho mostraram estabilidade nas magnitudes das taxas de proteção (positivas no caso do arroz e negativas no caso da soja). Os resultados para o milho mostram predomínio de proteção à atividade com reversão desta tendência nos dois últimos anos da série. 
As principais críticas sobre a forma de condução da abertura comercial e as implicações sobre a proteção efetiva da agricultura são feitas por Lopes (1995, 1995b). Segundo este autor, em uma economia aberta, a proteção nominal tem que convergir para a proteção efetiva. Contrariando este pressuposto, no processo de desgravação tarifária ocorrido entre 1990 e 1994, em geral teria permanecido proteção tarifária ao setor de insumos maior do que aquela associada aos produtos agrícolas.

Além de maior proteção relativa aos segmentos industriais produtores de insumos, Lopes (1994) aponta também que a discriminação à agricultura assume uma dimensão adicional quando os produtos processados de uma cadeia agroindustrial desfrutam de tarifas de importação maiores do que as tarifas associadas ao produto agrícola, como na cadeia do algodão.

O recuo na política de desgravação tarifária em 1995, com aumento nas tarifas de importação para setores industriais teria representado ainda maior discriminação ao setor agrícola. Entre os trabalhos que estimaram a taxa de proteção efetiva para produtos agrícolas após 1985 tem-se Kume (1996) e Jank e Lopes (1997) e Santos (1998).

Kume (1996) estimou a taxa de proteção efetiva por setores , utilizando a estrutura da matriz insumo-produto de 1985. Verificou, no contexto geral assim como também para o setor agropecuária, quedas das tarifas efetivas entre 1993 e 1994 e aumento destas em 1995, evidenciando, para este último ano, retrocesso no processo de liberalização comercial.

Jank e Lopes (1997) estimaram a taxa de proteção efetiva para o milho e apontam que este produto sofreu uma desproteção da ordem de $26 \%$ (com impostos e câmbio corrigido), contra valores para a mesma estimativa da ordem de $20 \%$ em 1990 e $45 \%$ em 1985.

Os resultados de Santos (1998) de TPE para o Estado do Paraná mostram, no caso do milho, proteção até 1994 (da ordem de 6 a 12\%) e taxação nos 3 últimos anos da série (1994 a 1996). Para o arroz mostram proteção positiva e elevada; no caso do algodão a pesquisa mostrou que, na década de noventa, as taxações à cultura 
foram intensificadas, o que teria contribuído para promover realocação de parte dos recursos produtivos antes direcionados para esta cultura em favor de outras atividades.

\subsection{Impactos das reformas sobre o setor produtivo agrícola}

Dentre os setores produtivos, a agricultura é considerada setor pioneiro na promoção da abertura comercial no país. Entre a transição de uma administração quase autárquica das políticas de preços e comercialização dos governos até os anos oitenta, com seus múltiplos programas de abastecimento, para uma conjuntura de maior liberdade de mercados, houve impactos consideráveis.

Neste ítem pretende-se, em primeiro lugar, discutir os impactos mais evidentes da liberalização comercial e da desregulamentação dos mercados sobre o setor produtivo agrícola. Em segundo lugar, faz-se uma reflexão sobre algumas questões que acabam sendo suscitadas a partir dos impactos que serão mencionados. Estas questões estão associadas: à importância de rediscutir as vantagens comparativas dos produtos, à redução nos estímulos à formação de estoques, e à participação efetiva do país nos mercados mundiais e regional de commodities.

Ao conjunto das reformas empreendidas na economia brasileira tanto em nível global quanto em nível setorial, tem-se associado dois grandes efeitos sobre o setor agrícola: (i) perda de dinamismo do setor com redução em seu ritmo de crescimento e mudança na composição da produção, e (ii) consolidação do país como importante importador de grãos.

O primeiro efeito é apontado por Gasques e Conceição (1997) os quais estimaram índices de produtividade total da agricultura brasileira para o período 1976/94 e constataram descontinuidade do padrão de crescimento do setor ao longo do tempo.

Para aqueles autores este efeito, em grande medida, seria explicado pela acentuada mudança que tem ocorrido na composição do produto total do setor 
agropecuária, com maior participação dos subsetores frutas e pecuária e perda de participação do subsetor grãos ${ }^{16}$. Especificamente, mostrou-se que a participação do grupo grãos na composição do produto total setorial teria passado de $37,2 \%$ em 1984 para $32 \%$ em 1994, enquanto que a participação do grupo frutas teria variado de $8,2 \%$ para $14,1 \%$ no mesmo período. Já a produção animal teria passado de $23,7 \%$ em 1984 para 31,6\% em 1993. Entretanto, apontam os autores, o aumento de participação de ambos os grupos não teria compensado a perda de participação do grupo grãos.

Na figura 2 pode-se visualizar que a área plantada para o total de grãos tem sofrido retrações ao longo do tempo; entre a média dos anos-safras 87/88 88/89 (duas grandes safras) e 95/96 - 96/97, a área plantada sofreu um decréscimo da ordem de $13,7 \% .{ }^{17}$ Diferentemente do padrão observado para a evolução da área, a produção permanece crescendo positivamente porém, com um ritmo de crescimento menor relativamente aos verificados nas décadas de setenta e oitenta (Gasques e Conceição, 1997) ${ }^{18}$.

Em geral argumenta-se que o desmantelamento das estruturas de proteção a alguns produtos e a redução dos recursos destinados à política de preços mínimos cumpriram o papel de acelerar o decréscimo da área plantada dos principais produtos, sem estar acompanhado de aumento correspondente na área plantada de outros produtos (David e Nonenberg, 1997; Gasques e Conceição, 1997). Isto revela que a análise dos efeitos do processo de liberalização comercial e desregulamentação dos mercados sobre a formação dos preços (e portanto da renda agrícola) assume uma importância especial.

\footnotetext{
${ }^{16} \mathrm{O}$ conjunto de produtos denominado grãos compreende arroz, algodão, amendoim, feijão, mamona, milho, soja, aveia, centeio e trigo.

${ }^{17}$ Refere-se ao mesmo conjunto de produtos identificado na nota de rodapé anterior.

18 Estes autores apresentam estimativas de taxas anuais de crescimento da produtividade total da agricultura para os subperíodos 1976-85 e 1986-94. Para o primeiro subperíodo, a taxa de crescimento anual da produtividade total indicada é da ordem de 4,5\% enquanto que para o segundo subperíodo a mesma teria sido da ordem de $3,11 \%$. Bacha e Rocha (1997) também mostram crescimento positivo da produção das vinte e oito principais culturas nesta década.
} 


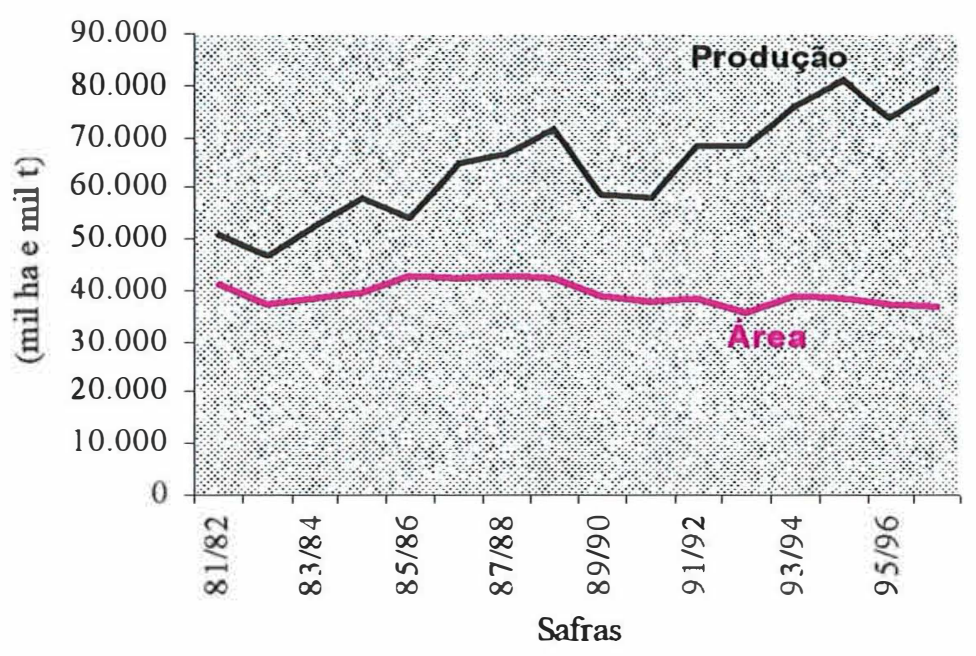

Fonte: $\mathrm{CONAB}$

Figura 2 - Evolução da área e produção de grãos. Brasil, safras 1981/82 a $1996 / 97$

\section{O aumento das importações agrícolas}

Um dos impactos mais apontados por alguns analistas de economia agrícola e lideranças do setor com relação às alterações associadas com a liberalização da economia diz respeito à constatação de que a partir do final da década passada, o abastecimento interno encontra-se muito mais dependente do mercado externo, com evidentes implicações sobre a formação de preços e renda internos [Jank, (1994); Lopes, (1995b,1996); David e Nonnenberg (1996); Rezende et al. (1997)]. Esta constatação contrapôs-se às evidências de melhoria no padrão de abastecimento interno com reduções nas importações de alimentos que teria ocorrido no primeiro quinqüênio dos anos 80 (Rezende, 1988). 
Nos anos noventa, o conjunto das importações agrícolas revelaram expressivo crescimento. No período 1990-96, conforme Santo e Severo (1997), este crescimento teria sido da ordem de $180 \%$. Entretanto, embora tal crescimento tenha sido significativo, a participação destas no conjunto das importações do país não teria sofrido alterações, permanecendo na proporção de $12 \%$, uma vez que as importações totais também aumentaram muito ${ }^{19}$. Dentre as importações totais de produtos agrícolas da categoria básicos, aqueles autores apontam destaque para o crescimento das importações de trigo (197\%), algodão (448\%), arroz (116\%), alho (88\%) e milho $(90,87 \% \text { entre } 1990 \text { e } 1995)^{20}$.

Uma questão importante que permeia a discussão sobre os impactos das importações de produtos agrícolas é que tal crescimento do volume importado não estaria respaldado na correspondência do déficit da produção interna sobre o consumo, mas sim, estaria aumentando em muito a disponibilidade interna de alguns produtos, o que é evidenciado por grandes estoques de passagem (como será visto no próximo capítulo nos casos do arroz e milho).

Em seminário realizado por lideranças rurais expressou-se grande preocupação com o fato da formação dos preços internos de produtos de consumo doméstico como arroz, milho, algodão e trigo estar sendo muito afetada pelos movimentos dos preços internacionais, como conseqüência tanto das mụdanças nas políticas setoriais no sentido de desregulamentar os mercados quanto do processo de abertura da economia a partir do final dos anos oitenta ${ }^{21}$. Tais preocupações em parte motivaram a realização da presente pesquisa, que objetiva verificar exatamente em que

\footnotetext{
${ }^{19}$ Não obstante o crescimento das importaçōes deve-se considerar também que, em temos líquidos, o setor tem oferecido contribuição positiva no saldo da balança comercial. A participação das exportações agroindustriais frente às exportações totais teria aumentado de $26 \%$ em 1990 para $32 \%$ em 1996 . Neste ano, enquanto o déficit comercial do país foi de US\$ 5,5 bilhões, a agricultura isoladamente teria contribuído com um superávit de US $\$ 8,5$ bilhões.

$20 \mathrm{Na}$ estrutura da balança comercial agrícola os produtos são classificados como básicos, semimanufaturados e manufaturados. Os produtos básicos compreendem os cereais, carnes, pescados, frutas e animais vivos. O crescimento das importações totais para esta categoria foi de $124 \%$ contra um crescimento de $197 \%$ e $359 \%$ respectivamente nas categorias semimanufaturados e manufaturados.

${ }^{21}$ Tais preocupações foram expressas no seminário nacional: Renda rural e emprego na agricultura. Comissão de Agricultura e Política Rural da Câmara dos Deputados. Brasília, 3 de setembro de 1997.
} 
medida preços internos e externos têm apresentado uma tendência comum de longo prazo.

Para Jank (1994) um fato inédito nos anos 90 é que, mesmo safras consideradas boas ou normais, como as de 1992 e 1993 não foram seguidas de queda nos volumes importados, mas sim no surgimento de volumes recordes de importações em 1993.

Neste contexto, para Mendonça de Barros e Miranda (1998, p. 167), em uma economia aberta, as importações frequientes devem ser entendidas com mais naturalidade, compondo parte das estratégias de abastecimento para complementar as necessidades de consumo doméstico . Segundo estes “(...) a abertura da economia não é bem compreendida, pois é normal exportar na safra e importar na entressafra, transferindo-se os custos de carregamento de estoques para o resto do mundo (...)", (Mendonça de Barros e Miranda, 1998, p.132).

Além dos fatores já mencionados anteriormente e explicativos do crescimento das importações nesta década, a nível interno atuaram também para explicar aquele fenômeno, problemas relacionados a infra-estrutura e de logística, o alcance relativamente mais limitado das políticas de preços e armazenagem, além das questões associadas a vantagens comparativas e competitividade.

As ineficiências na área de infra-estrutura, que se acentuaram com a carência de investimentos nos anos oitenta, acabam resultando em custos adicionais (os chamados "custos Brasil") que oneram as atividades produtivas não só nos segmentos produtivos da agricultura propriamente, mas também às cadeias produtivas a eles conectadas e, por conseguinte, a todo complexo agroindustrial brasileiro. Esta questão, associada a carências relacionadas à logística de transportes, explica, por exemplo, a conveniência de importar milho da Argentina para o nordeste ao invés de removê-lo da região Centro-Sul do país.

$\mathrm{Na}$ verdade, em um contexto de abertura comercial e em uma perspectiva de integração regional, os impactos das importações de produtos agrícolas, assim como a situação do auto-abastecimento, precisam ser abordados ampliando-se o escopo da análise para inserir, além de reflexões sobre o papel das políticas setoriais 
internas (especialmente políticas de preços) ${ }^{22}$, a competitividade interna (frente aos parceiros comerciais e especialmente considerando-se os do Mercosul) e a questão das vantagens comparativas .

$\mathrm{Na}$ discussão de competitividade e vantagens comparativas, Lafay $(1979)^{23}$, em David e Nonnenberg (1997, p.7), define a competitividade como sendo a comparação entre dois ou vários países para um produto determinado e a vantagem comparativa como sendo a comparação entre diferentes produtos para um país dado, ou seja, como melhor utilizar os recursos disponíveis. Para Lafay, a competitivade, de maneira geral, está subordinada à conjuntura macroeconômica e à taxa de câmbio real, enquanto as vantagens comparativas têm um caráter estrutural e são mais associadas a cada segmento produtivo.

David e Nonnenberg (1997) apropriadamente lembram que um processo de integração comercial induz à especialização da produção, significando que cada uma das economias integradas irá aumentar a produção de um determinado grupo de bens e reduzir a produção de outros, podendo ser o ritmo de cada um desses processos diferenciado. Nas palavras dos autores:

“(...) A criação de vantagens comparativas em determinados setores, até que resulte em aumento da produção, necessitará de investimentos, com os respectivos prazos de maturação. Por outro lado, a redução da competitividade de setores que perdem competitividade tende a ser muito mais rápida, sobretudo naqueles em que a mera redução das margens de lucro não for suficiente para permitir reduzir os preços finais(...)"David e Nonnenberg (1997, p. 223).

Neste contexto, deve-se notar que no segmento produtivo da agricultura estes movimentos de ajustes estão sendo observados, especialmente no caso de alguns grãos e fibras as evidências são redução de competitividade no caso do algodão, arroz e trigo e ganhos de competitividade em café, soja, aves e açúcar, segundo os autores acima.

\footnotetext{
22 Já discutido anteriormente

${ }^{23}$ Lafay , G. Dynamique de la specialisation internationale. Paris: Economica, 1979.
} 
Apesar de alguns subsetores da agricultura serem bastante sensíveis à liberalização comercial, para Zylbersztajn e Jank (1996), o setor agroindustrial brasileiro tende a auferir ganhos, em termos globais, no balanço do comércio intra e extra Mercosul porque as importações brasileiras compõem-se basicamente de produtos "commoditizados", sendo insignificantes as importações de produtos semi-elaborados e produtos de alto valor adicionado (agroindustrializados). Para os autores, no Mercosul, a Argentina seria mais eficiente na produção de grãos (milho, arroz trigo, etc.), enquanto o Brasil mostra-se mais competitivo nos sistemas integrados de produção intensiva de carnes (aves e suínos) e laticínios.

Para finalizar este capítulo, pode-se dizer que as mudanças promovidas nesta década, tanto aquelas associadas às políticas internas que afetam os mercados de produtos, quanto as políticas que determinam as relações de comércio internacional, não avançaram no sentido de oferecer as condições ideais para integração de mercados. Muitos analistas e lideranças do setor agroindustrial apontam que o ideal seria ter-se, além de desregulamentação, câmbio livre, eliminação do custo Brasil e ausência de diferenciais no tratamento da política comercial (tarifas) entre setores de uma mesma cadeia produtiva.

Mesmo quanto à integração regional no âmbito do Mercosul, o ideal, para uma abordagem de integração de mercados, seria se, ao invés de uma União Aduaneira, que este mercado já estivesse no estágio de mercado comum $^{24}$ ou união econômica.

Entretanto, hoje tem-se que o comércio mundial de commodities é em grande parte realizado por empresas integradas globalmente (multinacionais e nacionais), de forma que as alterações nos determinantes externos e internos abordados neste capítulo, os quais foram iniciados no final da década passada e ganharam contornos mais nítidos nesta década, sem dúvida facilitaram a atuação dos mecanismos de arbitragem. Isto contribuiu para que os preços de commodities agrícolas tenham relação com os preços internacionais (tanto aquelas commodities em que o país participa no mercado internacional como exportador quanto aquelas mais voltadas para o consumo interno ${ }^{25}$ e nas quais o país se configura como importador líquido ou eventual).

\footnotetext{
${ }^{24}$ Livre circulação de bens, serviços e capitais e harmonização de políticas.

${ }^{25}$ Excetuando-se o feijão e a mandioca.
} 


\section{REFERENCIAL TEÓRICO}

Neste capítulo são desenvolvidos os conceitos básicos nos quais se apoiam a análise das relações interregionais de preços, que são: o conceito de integração de mercados, a Lei do Preço Único (LPU) e a teoria de Paridade do Poder de Compra (PPC).

Apresenta-se também, uma revisão de literatura mais específica sobre a abordagem de integração de mercados e Lei do Preço Único.

\subsection{Integração de mercados}

O conceito de integração de mercados decorre dos princípios básicos da "teoria espacial de preços", que, por sua vez, surge da "teoria da localização", cuja origem remonta ao século XIX. A primeira formulação representativa da dinâmica de integração de mercados foi sugerida com o trabalho de Samuelson (1952), adaptada por Bawden (1966) para análises envolvendo o mercado internacional e desenvolvida por Takayama e Judge (1971). Estes trabalhos marcaram o princípio da pesquisa aplicada ao campo de modelos de equilíbrio espacial, utilizando técnicas de programação matemática para definição do equilíbrio entre preços e quantidades.

Segundo a teoria espacial dos preços, se os mercados de um mesmo bem estão separados geograficamente, os preços internos serão determinados pela intersecção da demanda e oferta locais. Uma vez que as funções de demanda e oferta locais podem variar entre mercados, os preços internos de equilíbrio podem também ser distintos. 
Entretanto, num contexto de distintos níveis de preços entre dois mercados, se a diferença entre os níveis de preços de equilíbrio for maior ou igual ao custo unitário de transporte e não existirem barreiras ao comércio, as ações de arbitragem $^{26}$ encarregar-se-ão de promover a remoção dos produtos do mercado com preço menor para o mercado com preço maior. O aumento da demanda pela mercadoria no mercado de preço menor fará com que este aumente, ocorrendo o inverso com o preço no mercado de preço maior. O equilíbrio será alcançado quando: $i$ ) a diferença de preços for igualada aos custos de transporte após iniciado o fluxo de comércio, e ii) os fluxos de comércio interregional se compensarem .

A formação do equilíbrio espacial está representada na figura 3. Nesta, A1 e A2 representam os níveis de preços de equilíbrio interno, P1 e P2 são os preços de equilíbrio espacial na região 1 e 2 respectivamente. O custo de transporte de 1 para 2 é T12; A1<A2 e A2 - A1> T12. Portanto, haverá fluxo de comércio da região 1 para a região 2 e, por conseguinte, elevação de preços na primeira e diminuição de preços na segunda. $\mathrm{O}$ equilíbrio será alcançado no ponto em que $\mathrm{P} 2=\mathrm{P} 1+\mathrm{T} 12$ (note-se que o eixo da região 1 encontra-se acima do eixo da região 2 em dimensão igual ao custo de transporte, T12). No contexto, E12=-E21, onde E12 representa as exportaçōes da região 1 para 2, e -E21 as importaçōes da região 2 para 1.

\footnotetext{
Arbitragem de preços é definida como atividade especulativa que resulta da existência de alguns compradores e vendedores que desejam comprar o mesmo bem em vários mercados alternativos e escolhem os mercados de acordo com os custos e lucratividade dos mesmos.
} 
Preço

Região 2

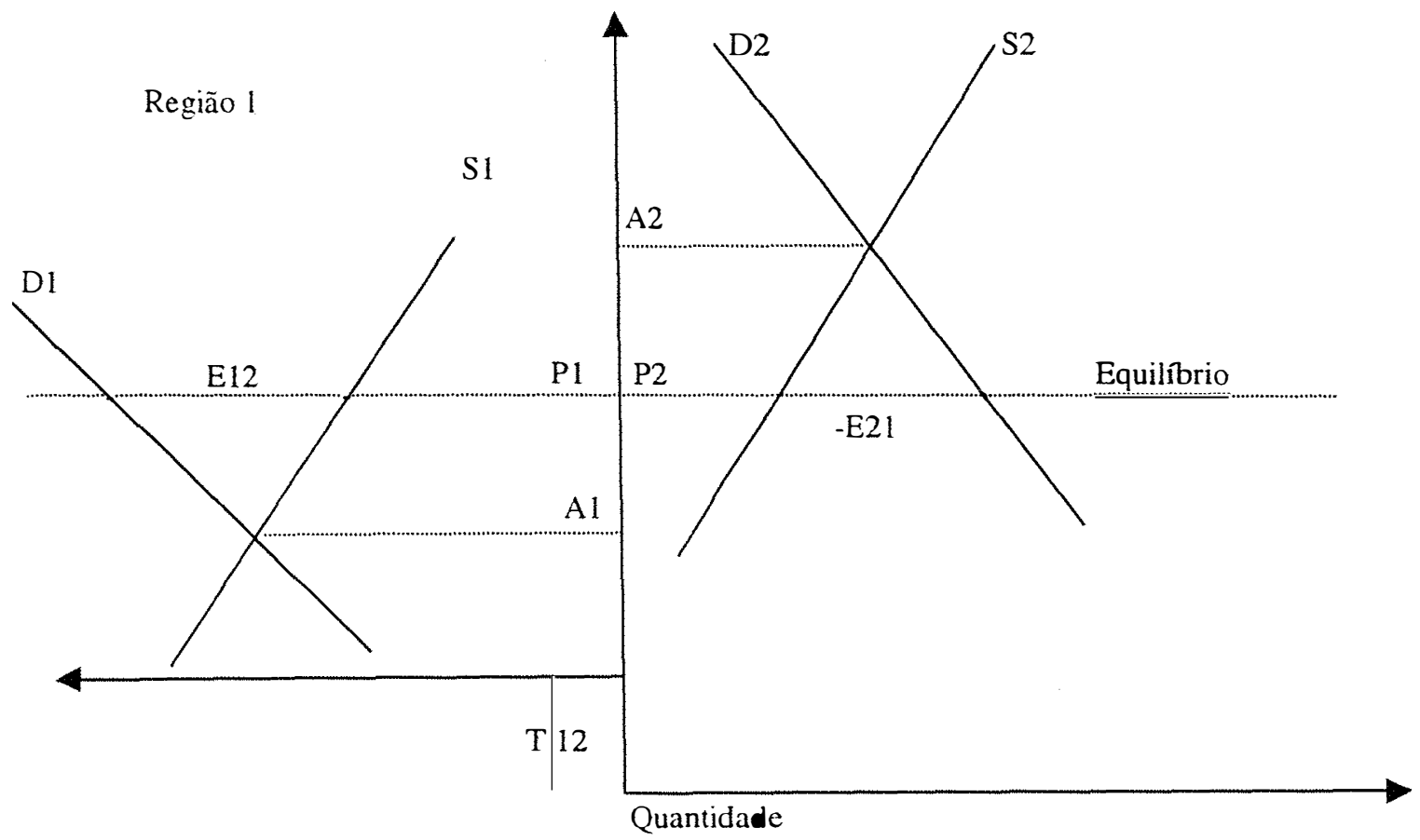

Figura 3 - Modelo de equilíbrio espacial.

Fonte: A partir de SAMUELSON (1952).

Custos de transporte são entendidos genericamente como sinônimos de "custos de transação". O custo de transação por unidade do produto representa o custo de transporte propriamente dito e outros custos associados ao translado do bem, como seguros, tarifas. manejo, etc..

No contexto do comércio internacional, segundo a estrutura de Samuelson (1952), Takayama e Judge (1971) e Bawden (1966) tem-se, para diversos países, curvas de oferta e demanda para várias commodities. Também são conhecidos os custos de transporte entre os países. O que se procura são preços competitivos em todos os países e as respectivas quantidades transacionadas, por país de origem e destino. A solução é um problema de programação matemática na qual a função objetivo é a soma dos excedentes de importadores e exportadores em todos os países. Do lado da oferta, as restrições especificam a igualdade entre as exportações totais de cada país e os totais 
destinados para diferentes importadores. Do lado da demanda, especifica-se igualdade entre importações totais de cada país e os totais recebidos de diferentes exportadores.

Segundo Lopes, A.I. (1996), a diferença entre os enfoques de integração de mercados e modelos de equilíbrio espacial está em que, nestes, o objetivo é determinar, a partir de funções de oferta e demanda regionais e dos custos de transação, os valores de preços e quantidades transacionados. O enfoque de integração de mercados, por outro lado, já considera os preços disponíveis para mercados separados como realização deste equilíbrio. Deste modo, esta abordagem procura evidências de que a igualdade entre preços, prevista pela teoria espacial (observados os custos de transação), encontra correspondência nos mercados reais.

Várias definições são encontradas para integração de mercados. Em geral, cada interpretação é ligada a um instrumento analítico para teste. Para Faminon e Benson (1990) se a permanência de comércio entre duas regiões é assegurada de forma que os preços entre os mesmos passam a apresentar relação de interdependência, então os mercados são ditos espacialmente integrados. Neste sentido, integração de mercados é vinculada à abordagem de transmissão de preços, de forma que alterações no preço em um mercado são transmitidas por completo ao preço de outros mercados.

Já Monke e Petzel (1984) definem por integrados os mercados nos quais os preços de commodities diferenciadas segundo o local de origem, não apresentam comportamento independentes. Segundo estes autores, se existe elevado grau se substituibilidade na produção ou no consumo, os choques provocados por mudanças na oferta e demanda de um produto transmitir-se-ão ao resto dos produtos de um mesmo grupo. Este mecanismo conduz à existência de um vínculo entre preços de produtos diferenciados, podendo seus mercados ser considerados integrados.

Medidas de integração de mercados são vistas como elementos básicos para o entendimento de como mercados específicos trabalham. Parte dos trabalhos que discutem medidas de integração de mercados fazem-no a partir de uma perspectiva regional (Ravallion,1986; Goodwin e Schroeder,1991; Williams e Bewley,1993; Bittencourt, 1995), enquanto outros adotam uma perspectiva internacional. Neste último 
caso pode-se considerar todos os trabalhos que testam a validade da Lei do Preço Único no mercado internacional ${ }^{27}$ e também os trabalhos de Monke e Petzel, (1984), Kolstad e Burris (1986), dentre outros.

\subsection{A Lei do Preço Único}

A Lei do Preço Único postula que bens idênticos obedecem a uma regra de perfeita arbitragem no mercado internacional, significando dizer que tais bens são vendidos a um preço equivalente nos diferentes mercados, independente da moeda no qual é fixado, após feito o desconto para custos de transferências.

De maneira geral, preços entre dois países são expressos por um modelo similar ao de Richardson (1978):

$$
P_{1 t}=\mu P_{2 t}^{\beta_{1}} E_{t}^{\beta_{2}} T_{i t}^{\beta_{3}} R_{i t}^{\beta^{+}}
$$

onde $\mathrm{P}_{1 \mathrm{t}}$ é o preço em moeda do país 1 no tempo $\mathrm{t}$; $\mathrm{P}_{2 \mathrm{t}}$ é o preço do país 2 (em moeda corrente) no mesmo período, E é a taxa de câmbio (unidades de moeda do país 1 necessárias para obter uma unidade de moeda do país 2), $T_{i t}$ são os custos de transferência e $R_{4}$ são razões residuais para a existência de diferenças de preços entre os dois países e $\mu, \beta_{1}, \beta_{2}$ e $\beta_{3}$ são parâmetros.

Ausência total de arbitragem de preços sugere que $\beta_{1}, \beta_{2}, \beta_{3}=0$ e perfeita arbitragem de preços, associada a alto grau de substituibilidade entre commodities nos dois países sugere que $\mu, \beta_{1}, \beta_{2}, \beta_{3}=1$ e $\beta_{4}=0$; neste caso a expressão (1) torna-se a expressão da Lei do Preço Único em sua forma absoluta.

\footnotetext{
${ }^{27}$ Estes serão apresentados adiante.
} 
A versão relativa da LPU permite que o preço do país 1 seja proporcional ainda que não idêntico ao preço do país 2 , uma vez ajustado pelo tipo de câmbio e custo de transação. Isto significa que $\mu$ pode ser distinto da unidade.

A investigação da LPU como uma relação de longo prazo (estável) comumente é feita a partir da expressão (1) omitindo os termos T e R e inserindo-os no termo de erro. Desta forma, para commodities altamente substituíveis (homogêneas) com perfeita arbitragem de preços, a expressão da LPU, como expressão de uma relação de equilíbrio entre dois ou mais mercados nos quais mudanças no preço de equilíbrio em um mercado conduz a mudanças nos preços de equilíbrio nos outros mercados, pode ser representada pela relação da forma como a utilizada por Ardeni (1989), Jung e Doroodian (1994) e Karbuz e Jumah (1995), entre outros:

$$
P_{1 r}=\mu\left(P_{2 t} E\right)^{\beta}
$$

fazendo

$$
P^{*}{ }_{2 t}=P_{2 t} E
$$

tem-se,

$$
P_{1 t}=\mu\left(P_{2 r}^{*}\right)^{\beta}
$$

Esta relação de equilíbrio pode ser expressa colocando as variáveis de (4) em logarítmos:

$$
P_{1 t}=\mu+\beta P_{2 t}^{*}
$$

Se no longo prazo a expressão (5) é verdadeira, então a equação de regressão é escrita como:

$$
P_{1 t}=\mu+\beta P_{21}^{*}+\varepsilon_{1}
$$

onde $\varepsilon_{\mathrm{t}}$ representa os desvios do valor de equilíbrio em cada período.

$\mathrm{Na}$ formulação de equilíbrio espacial de Samuelson apresentada acima, a LPU é assegurada perfeitamente. Há um único preço de exportação para cada 
commodity, considerando o destino das exportações, e há um único preço de importação para cada commodity, considerando a origem das importações.

Para que a Lei do Preço Único para bens comerciáveis seja válida, uma condição suficiente é que os mercados envolvidos sejam caracterizados por competição pura e perfeita. Isto permitiria a existência de arbitragem perfeita. Além disso, se uma mesma commodity em dois mercados não apresenta características idênticas, devem entretanto ter elevada elasticidade de substituição na produção e consumo (Officer, 1986).

O que se observa entretanto, é a existência de alguma polêmica sobre em que medida o modelo de competição perfeita é capaz de explicar o comércio internacional em mercados agrícolas. Os principais elementos apontados como impeditivos da existência de perfeita arbitragem e competição perfeita são: práticas monopolistas de discriminação de preços nos mercados domésticos e estrangeiros e as práticas de grupos oligopolistas, com suas ações voltadas para estabilizar preços, que podem absorver os impactos de mudanças na taxa de câmbio em seus lucros, fazendo com que os preços de bens comerciáveis não se movam com a taxa de câmbio para assegurar a Lei do Preço Único.

Mesmo assim, o paradigma de competição perfeita é largamente usado na avaliação de comércio agrícola e políticas comerciais, encontrando-se implicitamente aceito nas formulações dos trabalhos que testam a Lei do Preço Único. Thompson $(1981)^{28}$, conforme Kolstad e Burris (1986) elaborou uma revisão de modelos de equilíbrio espacial e constatou que o paradigma de equilíbrio competitivo é o mais encontrado, relativamente a outros tipos de competição, em modelos de mercado internacional para trigo, arroz, milho, açúcar, carne, laranja e amendoim.

Ainda assim, Kolstad e Burris (1986) e Pick e Park (1991) apontam que, dentre as principais commodities agrícolas, apenas para o trigo tem-se encontrado

${ }^{28}$ Thompson, R.L. A survey of recent U.S. developments in international agricultural trade models. Washington, DC: U.S. Department of Agriculture Econ. Res. Serv. Bibio.n.21, sep.1981. 
evidências de que o paradigma de competição perfeita não se aplica para explicar os padrões de comércio.

Pick e Park (1991) procuraram inferir sobre a existência de poder de mercado dos Estados Unidos nos mercados mundiais de commodities, examinando a estrutura de competição das exportações agrícolas americanas nos mercados mundiais de algodão, trigo, milho e soja.

Poder de mercado, no caso, foi entendido como sendo a capacidade de um país de interferir no padrão de ajustamento dos preços das exportações em resposta a movimentos na taxa de câmbio. Especificamente, o trabalho acima procurou verificar a capacidade dos exportadores em ajustar os preços das exportações segundo a nação de destino, resultando em uma forma de discriminação de preços. Os resultados rejeitaram a hipótese de que as decisões de preço de exportação são consistentes com discriminação de preços entre mercados de destino para os casos do algodão, soja e milho. Forte evidência contra a estrutura competitiva foi obtida apenas para o mercado internacional de trigo.

\subsection{A Teoria da Paridade do Poder de Compra e a Lei do Preço Único}

A Teoria da Paridade do Poder de Compra (PPC) generaliza a lógica da lei do preço único para os preços agregados na economia. Assume que o processo de arbitragem de preços é condição necessária para determinar o nível da taxa de câmbio e estabelece, em função disto, que os preços são comparáveis em economias abertas.

Sob a PPC, $\mathrm{P}_{1}$ e $\mathrm{P}_{2}$, em (6), são índices de preços agregados e a taxa de câmbio é determinada simultaneamente com os níveis de preços em cada país, isto é, como taxa de conversão desses preços entre as economias, a taxa de câmbio reflete os níveis de preços nominais e é determinada pela razão dos níveis de preços agregados. Sob a LPU, $\mathrm{P}_{1}$ e $\mathrm{P}_{2}$ são preços de commodities específicas e a taxa de câmbio é considerada exógena. 
A versão absoluta da PPC assume arbitragem perfeita tal como a versão absoluta da LPU; neste caso, considera-se que a transmissão da taxa de câmbio seja instantânea e simétrica (Isard,1977; Protopapadakis e Stoll, 1983).

Para Ardeni (1989) sob taxas de câmbio fixas, perfeita arbitragem de commodities implica transmissão internacional de inflação (um aumento de um preço em unidades de moeda doméstica tem sua contrapartida no preço em moeda estrangeira) e efeitos instantâneos sobre preços nominais de ajustamentos da taxa de câmbio. Por outro lado, segundo o mesmo autor, a ausência transitória de arbitragem de preços de commodities pode contribuir para explicar volatilidade de curto-prazo de taxas de câmbio e o fenômeno do overshooting.

Para o caso de algumas commodities primárias (como metais e produtos agrícolas), a pressuposição de perfeita arbitragem é considerada por muitos autores como uma aproximação da realidade, dada a capacidade que têm os preços destes produtos de refletir com relativa facilidade a presença e qualidade de atributos considerados desejáveis, segundo o destino e origem das commodities (Goodwin, et al.,1990). Acredita-se também, que estas commodities sejam transacionadas em mercados preço-flexíveis, em oposição a mercados preço-fixo, comumente associados a produtos manufaturados (Ardeni, 1989). Além disso, considera-se que os preços das commodities primárias são geralmente considerados independentes do país de origem e que são idênticas ou perfeitamente substituíveis e, portanto, perfeitamente arbitradas.

A arbitragem de preços é, entretanto, usualmente reconhecida como sendo imperfeita, isto é, a transmissão internacional dos distúrbios não ocorre completamente através dos preços para todos os bens e geralmente não no curto prazo. A versão relativa da PPC baseia-se nesta observação de que a arbitragem não é plena ${ }^{29}$

\footnotetext{
${ }^{29}$ Neste caso, para melhor discutir a PPC, a equação (2) é representada por Zini Jr. (1993) como $P_{1}=q . e . P_{2}$ onde q é a taxa de paridade. A versão absoluta da paridade do poder de compra assume que a Lei do Preço Único é válida para todos os mercados (neste caso q assume valor 1). A versão relativa da PPC baseia-se na observação de que a arbitragem não é perfeita devido a desvios do ideal de competição perfeita . Neste caso, q é diferente de 1 . Com o crescimento dos preços individuais diferindo em magnitude entre duas economias, ajustes no câmbio nominal teriam o propósito de igualar a diferença entre as taxas de inflaçōes doméstica e internacional, a fim de preservar uma dada paridade considerada desejável $a$ priori. Uma discussāo ampla sobre a teoria da PPC pode ser encontrada em Zini Jr. (1993).
} 
devido à presença de imperfeições de mercado (monopólios locais e outras imperfeições).

No longo prazo, entretanto, a existência de transmissão internacional dos distúrbios através dos preços é geralmente aceita. Estudos empíricos elaborados a partir de índices de preços gerais geralmente dão suporte para a PPC como uma teoria de longo prazo, embora encontrem desvios de curto prazo. Contrariando a versão absoluta da LPU, diversos tipos de restrições ao comércio internacional (como tarifas alfandegárias, quotas, controles cambiais, barreiras não tarifárias) criam múltiplos preços e podem impedir que, no curto prazo, as oportunidades de arbitragem de preços sejam identificadas. Em uma perspectiva de longo prazo, entretanto, assume-se que a arbitragem de commodities ocorre e tende a promover equalização dos preços. Para este horizonte de tempo, a vigência de múltiplos preços associados aos diversos tipos de restrições ao comércio (políticas discriminatórias) ${ }^{30}$, acabam por incentivar a ação dos arbitradores, gerando a possibilidade de países participarem do mercado internacional simultaneamente como importadores e exportadores, para auferir ganhos com os diferenciais de preços.

\subsection{Revisão sobre trabalhos que testaram a LPU}

Testes para a Lei do Preço Único têm sido desenvolvidos para uma grande variedade de commodities. Em geral, verifica-se a apresentação tanto de resultados favoráveis à LPU, quanto de resultados que não confirmam a validade desta lei.

Isard (1977), Richardson (1978) e Ardeni (1989) são trabalhos apontados na literatura como não tendo encontrado suporte empírico para a LPU. Isard (1977), após

\footnotetext{
${ }^{30}$ Anania e McCalla (1991) propõem um modelo em que todas as políticas comerciais discriminatórias podem ser representadas por expressá-las em termos equivalentes a tarifas ou subsídios.
} 
comparar preços de várias commodities para os Estados Unidos e Alemanha conclui que a lei do preço único é sistematicamente violada pelos dados empíricos.

Já outros trabalhos voltados à análise do mercado internacional como os de Protopapadakis e Stoll (1986); Officer (1986), Goodwin, Grennes e Wohlgenant (1990); Baffes (1991); Bungiorno e Uusivuori (1992); Jung e Doroodian (1994), Karbuz e Jumah (1995), Lopes (1996), In e Inder (1997), Lima e Burnquist (1997) encontraram resultados que dão suporte à LPU, utilizando diferentes procedimentos metodológicos. ${ }^{31}$ Isard (1977), Richardson (1978) e Officer (1986) procederam aos testes da LPU adotando um esquema agregativo de commodities. Isard (1977) avaliou índices de preços para bens industriais no Canadá, Alemanha, Japão e concluiu que na realidade a LPU é sistematicamente violada por dados empíricos.

Richardson (1978) testou a presença de arbitragem de preços entre Canadá e Estados Unidos para vinte e dois grupos de commodities (a partir de 4 e 7 dígitos da Standard Industrial Classification); dentre os grupos, as commodities analisadas foram previamente divididas em 3 classificações: commodities com arbitragem aparentemente presente; commodities com arbitragem possivelmente presente e um grupo de commodities para as quais não foi evidenciada a presença de arbitragem de preços entre os países. As commodities agropecuárias estiveram representadas por dois grupos: produtos animais, papel e celulose (inseridas no grupo "commodities com arbitragem aparentemente presente"). Os resultados não foram favoráveis à validação da LPU: a hipótese de arbitragem perfeita foi rejeitada até mesmo para as commodities do primeiro grupo.

Officer (1986) adotou o seguinte esquema agregativo para testar a Lei do Preço Único: tomando dois países, os produtos brutos de ambos foram divididos em produtos transacionáveis e não transacionáveis no comércio exterior $^{32}$ e a paridade do

\footnotetext{
${ }^{31}$ As commodities cujos comportamentos de longo prazo dos preços foram avaliados são: trigo, soja, girassol, milho, sorgo e óleo de amendoim, (Goodwin et al., 1990); trigo, lã, chá, carne, açúcar, zinco e aço, (Baffes 1991); produtos florestais, papel e celulose, (Bungiorno e Uusivuori, 1992) e (Jung e Doroodian 1994); cacau e café (Karbuz e Jumah, 1995); suínos (Lopes, 1996); óleos e gorduras (In e Inder, 1997); grão e farelo de soja (Lima e Burnquist, 1997).

32 Denominados genericamente de tradables e nontradables.
} 
poder de compra de ambos os países foi definida nos mesmos termos (tradables e nontradables). Testes de igualdade de preços entre os países foram feitos para a categoria de tradables. Os resultados mostraram-se fortemente favoráveis à validação da LPU.

Atualmente entretanto, avaliação da LPU a partir de dados agregados tem sido alvo de críticas. Protopapadakis e Stoll (1983) criticam o uso de esquemas agregativos para proceder a testes sobre a LPU, argumentando que uma das dificuldades de estudos passados é que desenvolveram análises com produtos agrupados ou produtos para os quais não se tinha indicações de que a qualidade permaneceria uniforme ao longo do tempo. Como resultado a LPU podia ser assegurada para commodities individuais, enquanto falha para índices. Commodities em contratos futuros foram consideradas apropriadas para este tipo de trabalho, por serem bem definidas e com características que possivelmente permanecem constantes ao longo do tempo. Estes autores utilizaram dados semanais para commodities transacionadas em mercados futuros em diferentes países e concluíram que a LPU é assegurada no longo prazo, enquanto desvios desta são observados no curto-prazo

Para Protopapadakis e Stool (1983) os ajustamentos para a LPU são lentos e no longo prazo as oportunidades de lucro são aparentemente fáceis de identificar. Da mesma forma que estes autores, Karbuz e Jumah (1995) testaram a LPU utilizando dados de contratos futuros e contratos à vista.

Godwin et al. (1990) argumentam que uma grande falha em estudos conduzidos para testar a validade da LPU está na pressuposição de que a paridade de preços ocorre entre preços contemporâneos em mercados separados geograficamente. Para os autores, esta pressuposição omite o fato de que a arbitragem internacional e o comércio ocorrem ao longo do tempo e em mercados espacialmente separados, de forma que a paridade não seria esperada para preços contemporâneos à vista. Incorporaram expectativas na análise empírica da LPU e os resultados mostraram-se fortemente favoráveis à validação da LPU para as commodities agrícolas estudadas.

Ardeni (1989) afirma que a maioria dos trabalhos até então conduzidos para testar a validade da LPU não apresentou resultados confiáveis, pois teriam falhado 
em explorar certas propriedades de séries temporais (como estacionariedade). Este foi um dos primeiros a realizar testes para a LPU como uma relação de longo prazo usando a técnica de cointegração, tendo trabalhado com commodities agrícolas e metais, utilizando preços de quatro países, concluindo que a Lei do Preço Único é falha como uma relação de longo prazo.

Em contraposição aos resultados encontrados por Ardeni, o que se verifica é que o uso da técnica de cointegração para testar e existência de relações de longo prazo entre preços de commodities, tem permitido que vários trabalhos recentes encontrem resultados empíricos que dão suporte à evidência da LPU, como nos casos de Baffes (1991); Bungiorno e Uusivuori (1992); Goodwin (1992 a e b), Jung e Doroodian (1994); Karbuz e Jumah (1995); Lopes (1996), In e Inder (1997) e Lima e Burnquist (1997).

No Brasil praticamente não há trabalhos que tenham testado a Lei do Preço Único; Lima e Burnquist (1997) testaram este postulado para os preços do mercado internacional de soja em grãos e farelo de soja. Os resultados indicaram que a LPU não pode ser rejeitada para o mercado de soja em grãos, permitindo inferir que a competição existente entre os três países exportadores considerados na análise (Estados Unidos, Alemanha e Brasil) tende a conduzir os seus respectivos preços de exportação a um patamar comum de longo prazo. Para o farelo de soja, os resultados obtidos foram divergentes. 


\section{CARACTERÍSTICAS DA PRODUÇÃO E DOS MERCADOS DE ALGODÃO, ARROZ E MILHO}

A seguir, discute-se a evolução da produção, preços, importações e os impactos do conjunto de variáveis associadas à abertura comercial sobre o segmento produtivo, tomando em consideração, especificamente, os produtos objeto da análise empírica deste trabalho.

Apresenta-se também as evoluções dos preços nacionais e internacionais para as commodities estudadas. Nesta década, os mercados de commodities em geral foram abalados pela dissolução da União Soviética, fato que teria desencadeado transformações lentas na produção e no consumo tanto nos mercados do Leste Europeu como na antiga União Soviética, imprimindo tendência decrescente aos preços mundiais das commodities (Becerra, 1998), como será visto adiante.

\subsection{O mercado de Algodão}

Até o início dos anos oitenta o Brasil era importante produtor e exportador regular de algodão. A partir de 1988 aumentam as importações, as quais passam a representar participação crescente na composição da oferta total de algodão em pluma, em contraste com o padrão observado na década de 80 , quando o volume importado era pouco significativo. O volume produzido, por outro lado, passa a apresentar nítida tendência de queda.

As variáveis explicativas de tal perda de competitividade da cotonicultura (crescimento das importações com desestruturação da produção), estão 
associadas a fatores globais e específicos ao sistema produtivo. Quanto aos fatores globais pode-se citar a abertura comercial, a sobrevalorização cambial, o diferencial de taxas de juros internas e externas, o financiamento externo das importações e à evolução da conjuntura internacional do produto. A seguir procura-se rever a importância relativa de cada uma dessas variáveis procurando explicitar a forma como cada uma delas explica as alteraçōes na cotonicultura nacional.

No que se refere à evolução da política comercial, o algodão e os demais produtos da cadeia produtiva algodoeira teriam sido alvos de sistemáticas medidas restritivas ao comércio exterior até o final da década de oitenta. Em 1988 as exportações de algodão em pluma foram liberadas de restriçōes quantitativas e qualitativas ${ }^{33}$ (Barbosa. 1996). No mesmo ano, a alíquota de importação do algodão em pluma foi reduzida de $55 \%$ para $10 \%$ (quadro 3). Tal desgravação tarifária tem sido apontada como o principal fator explicativo do expressivo aumento das importações a partir deste ano.

Entre 1990 e 1994 o mercado brasileiro esteve totalmente aberto, via isenção das alíquotas de importação para o algodão em pluma em 1990 explicando, em grande parte, o forte aumento das importações no período, como será visto.

Uma crítica freqüentemente apontada com relação à condução do processo de abertura comercial na cadeia produtiva do algodão, refere-se à discriminação que teria sofrido esta matéria prima, que teve sua tarifa de importação zerada, enquanto a mesma queda de tarifas não foi extensiva aos insumos. Em 1990, enquanto o algodão em pluma gozava de alíquota zero, seus insumos desfrutavam de alíquotas entre $10 \%$ e $14 \%$, o que é interpretado como custo adicional ao segmento produtivo, (Barbosa 1996). A partir de janeiro de 1995, com a implantação do Mercosul, o algodão em pluma foi enquadrado na lista de exceções à Tarifa Externa Comum (TEC).

\footnotetext{
${ }^{33}$ Restrições qualitativas referem-se à autorização de exportações de excedentes de fibras de tipos inferiores, não utilizados nas indústrias nacionais, (Barbosa, 1996). Este trabalho discute, em análise retrospectiva, a evolução das políticas comerciais para o algodão.
} 
Quadro 3 - Alíquotas da Tarifa Aduaneira Brasileira de Produtos Têxteis de Algodão (em \%).

\begin{tabular}{|c|c|c|c|c|c|c|c|c|c|}
\hline & \multirow[b]{2}{*}{1986} & \multirow[b]{2}{*}{1988} & \multirow[b]{2}{*}{1990} & \multirow[b]{2}{*}{1991} & \multirow[b]{2}{*}{$1992^{(1)}$} & \multirow[b]{2}{*}{1993} & \multirow[b]{2}{*}{$1995^{(2 /)}$} & \multicolumn{2}{|c|}{1} \\
\hline & & & & & & & & $1997^{(1)}$ & 1998 \\
\hline Algodão pluma & 55 & 10 & 0 & 0 & 0 & 0 & 1 & $3 ; 6$ & 6 \\
\hline Fios de algodão & 85 & 30 & 20 & 20 & 20 & 15 & 10 & - & - \\
\hline Tecidos & 105 & 30 & 40 & 40 & $30 ; 20$ & 15 & - & - & - \\
\hline
\end{tabular}

Fonte: Carta Têxtil, a partir de Barbosa (1996), CONAB.

(1/) Duas indicações de alíquotas em um mesmo ano refere-se à mudança tarifária no ano.

${ }^{(2 /)}$ A partir de janeiro de 1995, com a implantação do Mercosul, o algodão foi enquadrado na lista de exceções à Tarifa Externa Comum.

A existência de financiamento às importações no mercado externo, com prazos mais dilatados (de até 360 dias) e taxas de juros mais atraentes do que as oferecidas no mercado interno (em torno de $8 \%$ ao ano), seriam estímulos adicionais para a internalização de importações. ${ }^{34}$ Rezende, Nonnenberg e Marques (1997) constataram que o forte crescimento das importações globais verificado entre $1994 \mathrm{e}$ 1995 esteve associado a um aumento da participação percentual das importações financiadas. Embora esse aumento tenha sido modesto quando se toma em consideração as importações globais (da ordem de 10\%), no caso de acesso a financiamento externo acoplado às importações de algodão, a parcela financiada teria alcançado, em 1996, $92 \%$ do total importado. ${ }^{35}$

\footnotetext{
${ }^{34}$ A este respeito Rezende et al. (1997) analisam a evolução das importações financiadas no período $1991 / 96$ e as vinculações destas com as arbitragens de taxas de juros, internas e externas.

${ }^{35}$ No caso do arroz e do milho, teria havido uma redução das percentagens de importações financiadas, mas isso se deveu à proibição de importações a prazo desses dois produtos (inclusive do Mercosul, mas com exceção dos portos do Norte e NE).
} 


\section{Evolução da produção e comportamento dos preços}

Nos anos oitenta, a produção brasileira anual de algodão oscilou entre 586 e 860 mil toneladas e as exportações entre 100 e 180 mil toneladas, sendo as importações pouco significativas até 1988. Juntamente com o aumento das importações, a produção nacional sofie queda persistente e significativa entre 1992 e 1997, apresentando alguma recuperação na safra 1997/98 (figura 4). O volume produzido, que em 1992 perfazia 90\% das necessidades de consumo, chega a suprir apenas 39\% destas no ano safra 96/97, como mostra a coluna 6 do quadro 4.

A redução da área cultivada foi ainda mais drástica do que o nível de redução da produção global. Como mostra a figura 4, a área cultivada total passa de um patamar de 3,6 milhões de hectares no início dos anos 80 para algo em torno de 900 mil hectares nas últimas safras - uma retração da ordem de 2,7 milhões de hectares nos últimos 15 anos.

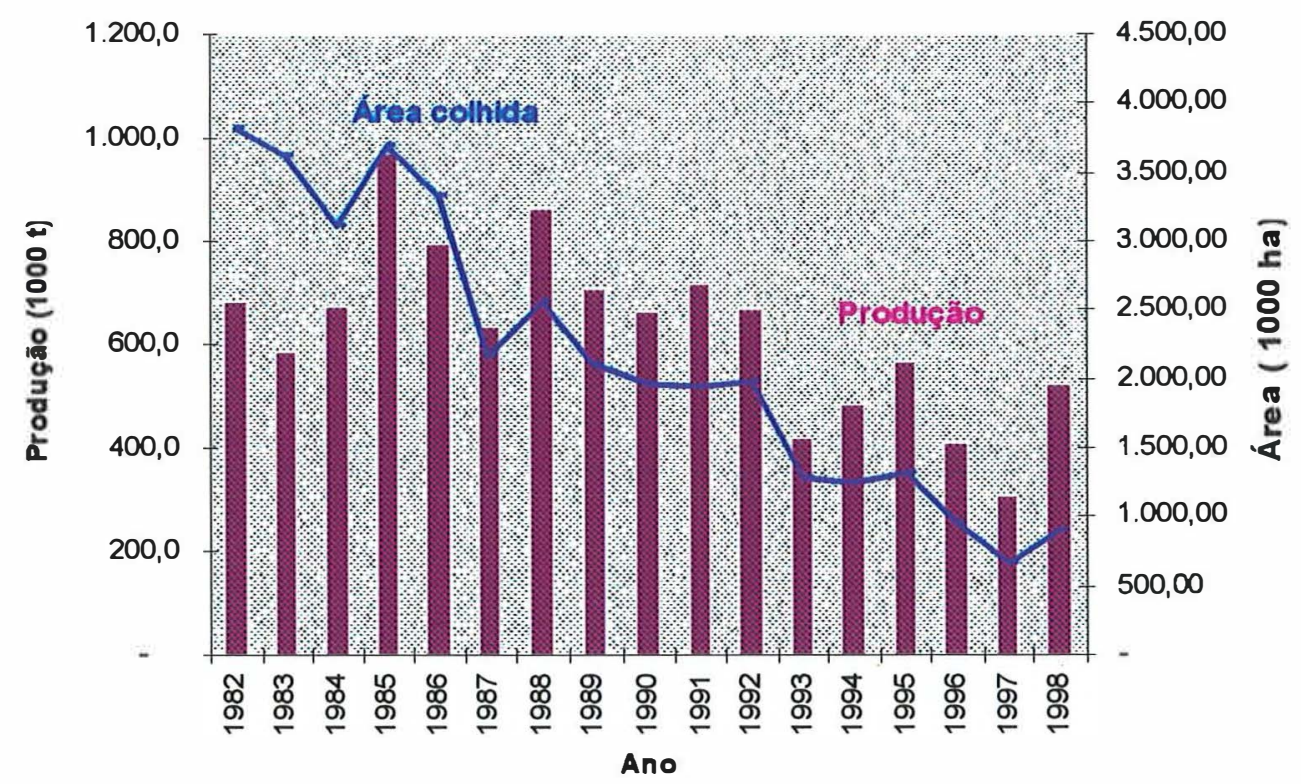

Fonte: CONAB.

Figura 4 - Área plantada e produção de algodão em pluma no Brasil (1982 - 1998). 
Quadro 4 - Quadro de suprimento anual de algodão em pluma (mil toneladas).

\begin{tabular}{|c|c|c|c|c|c|c|c|}
\hline $\begin{array}{l}\text { Anol } \\
\text { Safra }\end{array}$ & Produção & Importação & $\begin{array}{c}\text { Consu } \\
\text { mo }\end{array}$ & $\begin{array}{c}\text { Exporta } \\
\text { ção } \\
(4) \\
\end{array}$ & $\begin{array}{c}\text { Estoques } \\
\text { de } \\
\text { Passagem } \\
(5) \\
\end{array}$ & $\begin{array}{c}\text { Produção/ } \\
\text { Consumo } \\
(6) \\
\end{array}$ & $\begin{array}{l}\text { Import./Con- } \\
\text { sumo }(\%) \\
{[(2) /(3) * 100]} \\
(7)\end{array}$ \\
\hline $82 / 83$ & 586,3 & 2,4 & 556,7 & 180,2 & 13,8 & 1.05 & 0,4 \\
\hline $83 / 84$ & 674,5 & 7,8 & 555,2 & 32,3 & 108,6 & 1.21 & 1,4 \\
\hline $84 / 85$ & 968,8 & 20,5 & 631,4 & 86,6 & 379,9 & 1.53 & 3,2 \\
\hline $85 / 86$ & 793,4 & 67,4 & 736,6 & 36,6 & 467,5 & 1.08 & 9,1 \\
\hline $86 / 87$ & 633,4 & 30,0 & 774,7 & 174,0 & 182,2 & 0.82 & 3,9 \\
\hline $87 / 88$ & 863,6 & 81,0 & 838,0 & 35,0 & 253,8 & 1.03 & 9,7 \\
\hline $88 / 89$ & 709,3 & 132,1 & 810,0 & 160,0 & 125,2 & 0.87 & 16,3 \\
\hline $89 / 90$ & 665.7 & 86,1 & 730,0 & 110,6 & 36,4 & 0.91 & 11,8 \\
\hline $90 / 91$ & 717,0 & 105,9 & 718,1 & 124,3 & 16,9 & 0.99 & 14,7 \\
\hline $91 / 92$ & 667,1 & 167,8 & 741,6 & 33,8 & 76,4 & 0.90 & 22,6 \\
\hline $92 / 93$ & 420,2 & 501,2 & 829,5 & 7,4 & 160,9 & 0.51 & 60,4 \\
\hline $93 / 94$ & 483,1 & 367,3 & 836,6 & 4,3 & 170,4 & 0.58 & 43,9 \\
\hline $94 / 95$ & 537,1 & 282,3 & 803,7 & 52,5 & 133,5 & 0.67 & 35,1 \\
\hline $95 / 96$ & 410,0 & 468,2 & 826,1 & 1,6 & 184,1 & 0.50 & 56,7 \\
\hline $96 / 97$ & 305,7 & 470,8 & 791,3 & 0,3 & 169,0 & 0.39 & 59,5 \\
\hline $97 / 98$ & 411,7 & 350,0 & 930,7 & 5,0 & 250,7 & 0.44 & 37,6 \\
\hline $98 / 99^{*}$ & 489,4 & 300,0 & 700,0 & 3,1 & 224.5 & 0,70 & 42,9 \\
\hline
\end{tabular}

Estimativa.

Fonte: CONAB.

Por outro lado, a proporção do volume importado em relação ao consumo passa de 9,7\% em 1988 para cerca de 60\% nas safras 1992/93 e 1996/97. Nos anos de 1993 e 1997 as importações foram recordes, chegando a atingir 60\% do consumo total, seguidos dos anos safra 95/96 e 93/94 quando estas representaram, respectivamente, $56,7 \%$ e $43,9 \%$ do mesmo, o que pode ser observado a partir dos dados do quadro 4 (coluna 7).

Aspecto interessante na dinâmica da cotonicultura nacional refere-se à reestruturação produtiva por que esta tem passado, de forma que aquele movimento de queda da produção com retração da área cultivada não afetou de maneira uniforme as regiões produtivas do país. Ao contrário da tendência geral do país, a região CentroOeste tem apresentado crescimento de área, produção e produtividade. Nesta região, a 
tecnologia aplicada à lavoura difere em relação às demais regiões, em função do emprego de insumos modernos, dos incentivos oferecidos pelo governo do estado do Mato Grosso e, principalmente, em função da predominância de colheita mecânica enquanto as demais regiões fazem uso de colheita manual. A mecanização da cultura na região Centro-Oeste reduziu custos e imprimiu maior competitividade a esta região.

Neste contexto, a área plantada no Centro-Sul passa de 132,9 mil hectares em 1990 para 344,5 mil hectares em 1998, um crescimento de $159 \%$, enquanto o volume produzido aufere um crescimento de $151 \%$ no mesmo período. Movimentos em sentido contrário ocorreram nas regiões Sul, Nordeste e menos acentuadamente, na região Sudeste, com reduções tanto na área como na produção ${ }^{36}$.

Em função do desempenho relativamente mais favorável da região Centro-Sul , tem-se que a produtividade da cultura algodoeira para esta região mantémse ao nível ou acima da média mundial, com exceção dos períodos 1993/94 e 1995 a 1996 (a média mundial inclui a produtividade dos cultivos irrigados do Egito e da Turquia), o que pode ser visualizado na figura 5. A disparidade regional entre os rendimentos obtidos no Brasil explica a razão porque a média de produtividade nacional permanece muito abaixo da mundial, porém com tendência consistente de crescimento.

\footnotetext{
${ }^{36}$ Os dados são da CONAB.
} 


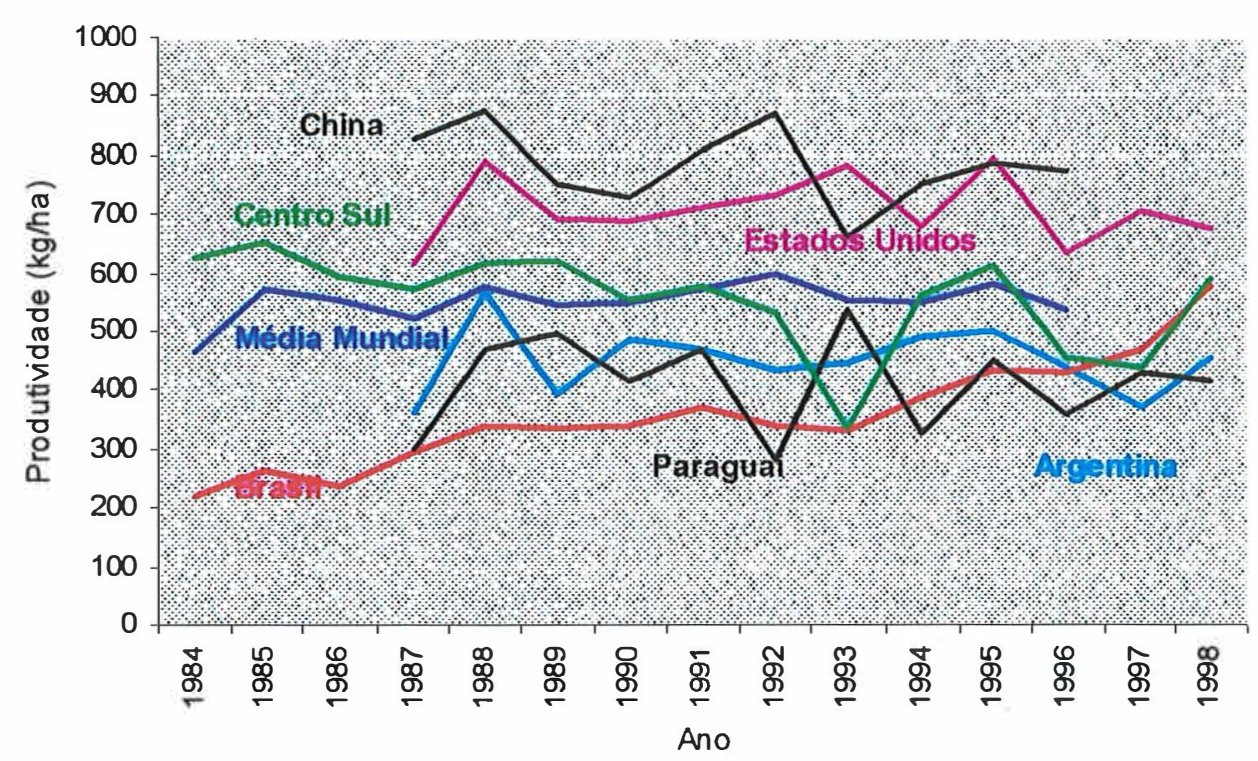

Fonte: USDA.

Figura 5 - Evolução das produtividades de algodão em pluma média mundial, Brasil (média nacional e região Centro-Sul), China, Estados Unidos, Argentina e Paraguai.

\section{O mercado mundial de algodão em pluma e o comportamento dos preços}

A produção mundial de algodão em pluma tem oscilado entre 16,5 e 22,2 milhões de toneladas entre as safras 1991/92 e 1996/97. O consumo mundial nas safras 1996/97 e 1997/98, tem sido em torno de 19,2 milhões de toneladas, neste destacandose China, Índia e Estados Unidos como países consumidores.

Entre os maiores produtores mundiais estão os Estados Unidos, China (se revezando na posição de maior produtor), Índia e Paquistão, enquanto os maiores importadores têm sido China, Indonésia, União Européia e o Brasil, este último tendo se posicionado como maior nação importadora em 1998.

A Argentina é o maior produtor da América do Sul e um dos 10 mundiais. O quadro 5 mostra a origem das importações brasileiras de algodão em pluma. Como as 
alíquotas de importação nos países do Mercosul estavam zeradas desde 1990, nota-se presença marcante da Argentina e Paraguai, os quais, conjuntamente, representam a principal origem das importações brasileiras.

\section{Quadro 5 - Importações Brasileiras de algodão em pluma por país de origem (1.000t).}

\begin{tabular}{|c|c|c|c|c|c|c|}
\hline PAÍS & \multicolumn{2}{|c|}{1992} & \multicolumn{2}{|c|}{1993} & \multicolumn{2}{|c|}{1994} \\
\hline & Quantidade & $\begin{array}{c}\% \text { sobre } \\
\text { total }\end{array}$ & Quantidade & $\begin{array}{c}\% \text { sobre } \\
\text { total }\end{array}$ & Quantidade & $\begin{array}{c}\% \text { sobre } \\
\text { total }\end{array}$ \\
\hline Argentina & 17,100 & 16,27 & 10,301 & 2,52 & 62,50 & 17,09 \\
\hline Paraguai & 85,252 & 81,10 & 110,058 & 26,91 & 76,38 & 20,89 \\
\hline Estados Unidos & 1,144 & 1,10 & 56,843 & 13,90 & 64,45 & 17,62 \\
\hline Rússia & 52.584 & 50,03 & 78,394 & 19,17 & 76,91 & 21,03 \\
\hline Benin & - & - & 6,916 & 1,69 & 18,99 & 5,19 \\
\hline Uzbequistāo & - & - & 7.242 & 1,77 & 23,27 & 6,36 \\
\hline \multirow[t]{3}{*}{ Total } & 105,115 & & 408.935 & & 365,73 & \\
\hline & \multicolumn{2}{|c|}{1995} & \multicolumn{2}{|c|}{1996} & \multicolumn{2}{|c|}{1997} \\
\hline & Quantidade & $\begin{array}{c}\text { \% sobre } \\
\text { total }\end{array}$ & Quantidade & $\begin{array}{c}\% \text { sobre } \\
\text { total }\end{array}$ & Quantidade & $\begin{array}{c}\% \text { sobre } \\
\text { total }\end{array}$ \\
\hline Argentina & 34.79 & 12,34 & 44,09 & 7,76 & 152,71 & 33,75 \\
\hline Paraguai & 74.61 & 26,47 & 84,67 & 14,90 & 44,03 & 9,73 \\
\hline Estados Unidos & 42.95 & 15,24 & 41,44 & 7,29 & 55,81 & 12,33 \\
\hline Rússia & 20,17 & 7,16 & 249,00 & 43,82 & 8,89 & 1,96 \\
\hline Benin & 20.98 & 7,45 & 126,07 & 22,19 & 48,23 & 10,66 \\
\hline Uzbequistāo & 20.50 & 7,27 & 88.11 & 15,51 & 60,83 & 13,44 \\
\hline Total & 281 & & 568.17 & & 452,48 & \\
\hline
\end{tabular}

Fonte: CONAB.

O comportamento dos preços externos e internos exibem tendência decrescente a partir de 1990, com alguns picos de alta, como mostra a figura 6 na página 55.

No contexto do mercado internacional, o impacto do colapso das economias do Leste Europeu e da antiga União Soviética teria começado em 1991/92, segundo Becerra (1998). Neste período, a oferta do algodão não exportado da Ásia Central e a forte redução no consumo da antiga União Soviética conduziram a um acúmulo de estoques, tornados disponíveis no mercado internacional. Paralelamente a 
estes fatos, teria ocorrido também, naquele período, aumento da produção mundial em virtude dos preços relativamente altos nos dois anos anteriores. Já as variações de preços entre 1994 e 1996 deveram-se a significativas oscilações na oferta mundial do produto (figura 6).

Em decorrência das alterações nas economias do Leste Europeu e antiga União Soviética, a produção mundial decresceu em torno de 2,7 milhões de toneladas em 1992/93 e um milhão de toneladas em 1993/94; neste último período, o volume produzido atingiu 16,9 milhões de toneladas, seguido de uma recuperação para 20,2 milhões de toneladas em 1995/96 e 19,5 milhões de toneladas em 1997/98.

Além da tendência decrescente dos preços associada à cotação do mercado externo, no contexto do mercado interno, contribuiu também para explicar esta tendência a isenção das tarifas de importações de algodão em pluma a partir de 1990.

No ano agrícola 1991/92 houve um crescimento da área plantada como resposta aos incentivos de crédito de custeio (Rezende et al.,1997). Na comercialização desta safra, apesar da atuação governamental mais intensa devido a retenção de estoques, via Empréstimos do Governo Federal, os preços sofreram grande queda até o ano agrícola 1993/94, conseqüência também do cenário internacional. A conjugação de baixos preços internacionais com condições de financiamento externo atrativas, resultou na internalização de volumes recordes de importações, as quais ultrapassaram a produção em 1993, como se pode observar no quadro 4 ( página 50).

Na safra 1996/97 a produção nacional atingiu o ponto mais baixo, 305,7 mil toneladas. Na safra seguinte (1997/98), houve expansão do cultivo alicerçada numa reação dos preços internos no primeiro semestre de 1997. Entretanto, a baixa demanda decorrente de um inverno pouco rigoroso, aliada ao crescimento das taxas de juros internos e no maior carregamento de estoques pelo segmento industrial, seriam fatores explicativos da baixa reação dos preços no período. 
Figura 6 - Evolução dos Preços de algodão em pluma: Índice B, Índice A (1990-1998), Paraguai e Argentina (1997-98)

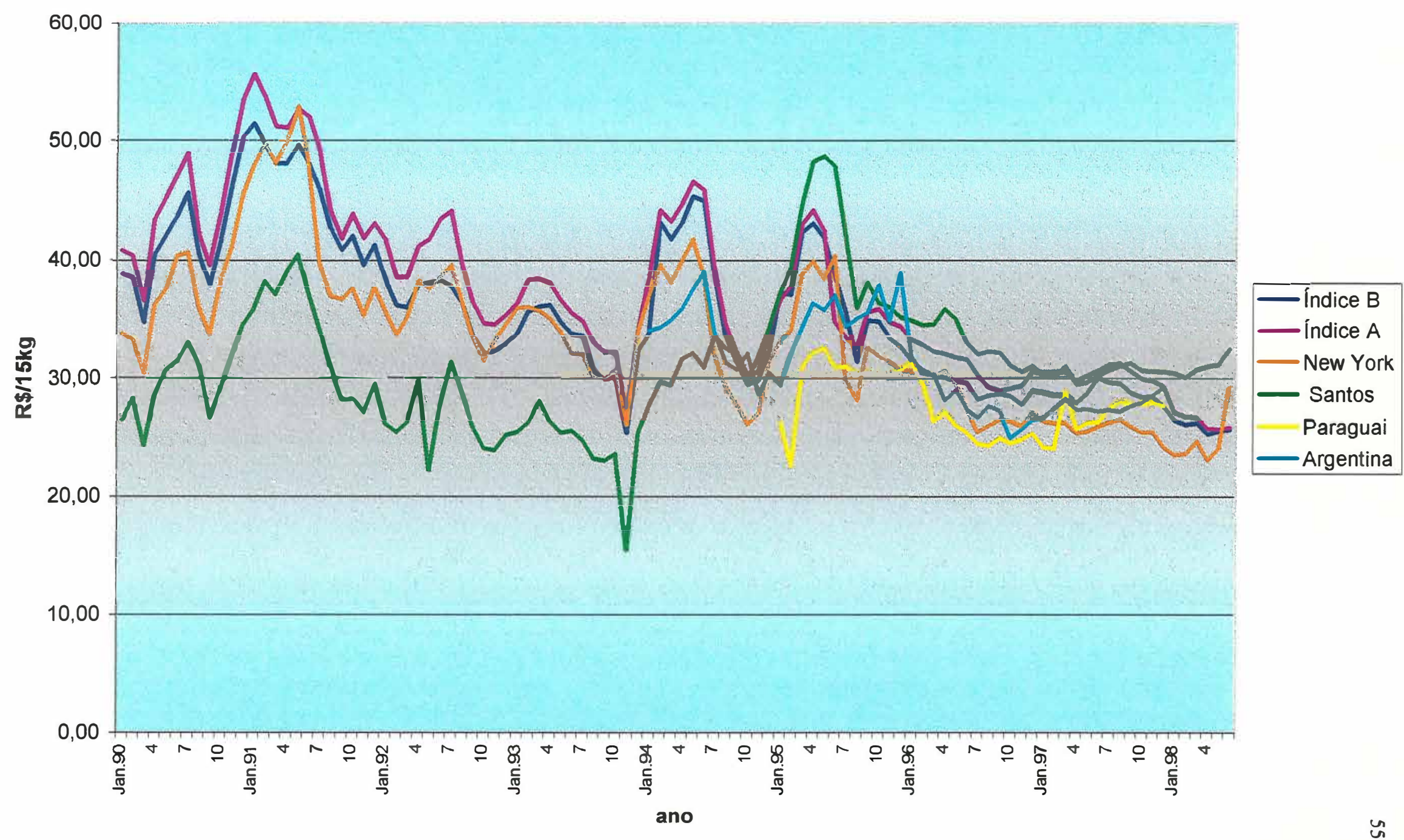


Como consequiência direta da apreciação da taxa de câmbio sobre os preços, segundo Urban (1995), houve períodos nos quais, embora se tenha observado aumento de preços no mercado internacional, em moeda nacional tal movimento não teria sido claramente constatado. Isto ocorreu entre julho e dezembro de 1994, quando os preços do algodão em pluma aumentaram $1,9 \%$ no mercado internacional, mas em moeda nacional mostraram queda da ordem de $28,9 \%$.

Além dos problemas inerentes ao sistema produtivo, a existência de financiamento às importações no mercado externo, com prazos mais dilatados (de até 360 dias) e taxas de juros mais atraentes do que as oferecidas no mercado interno (em torno de $8 \%$ ao ano), constituíram estímulos adicionais para a internalização de importações. ${ }^{37}$ Para Rezende, Nonnenberg e Marques (1997), de forma geral, o forte aumento das importações entre 1994 e 1995 teria contado com modesta contribuição de financiamentos a importações. Mas, especificamente no caso de acesso a financiamento externo acoplado às importações de algodão, a parcela financiada teria sido importante em alguns anos, chegando a 92\% do total importado em 1996.

\subsection{O mercado de arroz}

O comércio mundial do arroz é relativamente restrito, pois os maiores produtores são também os maiores consumidores. China, Índia, Indonésia, Bangladesh e Vietnã apresentam-se como maiores produtores e consumidores de arroz beneficiado, enquanto Tailândia, Estados Unidos e Vietnã destacam-se como maiores exportadores. A produção mundial de arroz estimada para a safra 1998/99 é da ordem de 555,8 milhões de toneladas ${ }^{38}$, mantendo o mesmo nível médio alcançado nas três safras anteriores.

A importância do Mercosul nas exportações do mercado mundial de arroz é pequena: a Argentina participou com 1,98\% do total exportado em 1996,

\footnotetext{
${ }^{37}$ A este respeito Rezende et al. (1997) analisam a evolução das importações financiadas no período $1991 / 96$ e as vinculações destas com as arbitragens de taxas de juros, internas e externas. ${ }^{38}$ Estimativa apresentada em "Indicadores da Agropecuária”, março de 1999. CONAB.
} 
enquanto o Uruguai contribuiu com $2,8 \%$. Por outro lado, do ponto de vista das importações, o Brasil tem se posicionado também como maior importador mundial em alguns anos desta década $(1993 / 94,1994 / 95$, 1997/88), além de ser o maior país produtor e consumidor de arroz depois dos países asiáticos.

Até 1990 o mercado brasileiro de arroz era protegido da concorrência externa por elevados níveis de tarifas de importação. Como se pode ver no quadro 6 , para o arroz em casca, até 1988 vigorou tarifa de importação de 45\%, passando para $20 \%$ neste ano e para $10 \%$ em 1993. A partir de 1995. passa a vigorar a Tarifa Externa Comum do Mercosul (TEC) para terceiros países, com tarifas de $20 \%$ para arroz em casca e $22 \%$ para arroz beneficiado.

\section{Quadro 6 - Alíquotas da tarifa aduaneira brasileira para importação de arroz} $(\mathrm{em} \%)$.

\begin{tabular}{|lccccccccc|}
\hline & $\mathbf{1 9 7 3}$ & $\mathbf{1 9 8 1}$ & $\mathbf{1 9 8 8}$ & $\mathbf{1 9 9 1}^{(\text {() }}$ & $\mathbf{1 9 9 3}$ & $\mathbf{1 9 9 5}$ & $\mathbf{1 9 9 6}^{(\text {() }}$ & $\mathbf{1 9 9 7}^{(1)}$ & $\mathbf{1 9 9 8}$ \\
\hline Beneficiado & 55 & 55 & 20 & $15 ; 10$ & 12 & 22 & $12 ; 22$ & $20 ; 23$ & 21 \\
Em casca & 45 & 45 & 20 & $15 ; 10$ & 10 & 20 & $10 ; 10$ & $10 ; 13$ & 13 \\
Outros & 45 & 45 & 20 & $15 ; 10$ & 10 & 20 & $10 ; 10$ & $10 ; 13$ & 13 \\
\hline
\end{tabular}

(i) Alterações tarifárias foram implementadas neste ano.

Fonte: CONAB.

No Mercosul, enquanto a produção brasileira gira em torno de 6,5 milhões de toneladas e o consumo em torno de 7,8 milhões, a Argentina e Uruguai, fornecedores habituais para o mercado brasileiro nos últimos cinco anos, produziram respectivamente em torno de 580 e 600 mil toneladas no ano/safra $1997 / 98^{39}$.

Apesar da abertura da economia brasileira ao mercado externo e a criação do Mercosul, a partir de 1991, terem propiciado mudanças significativas em relação à produção e comercialização de arroz no Brasil e nos demais países membros, algumas

\footnotetext{
${ }^{39}$ Estes dados são do Agrianual, 1999.
} 
iniciativas para favorecer os fluxos de comércio de arroz entre Brasil, Argentina e Uruguai foram implementadas já a partir de 1988. Neste ano, o Brasil teria iniciado a flexibilização do comércio de arroz com o Uruguai, com vistas a aumentar as importações deste país. com isenção da alíquota de importação (Programa de Expansão Comercial), (Aló e Manduca. 1998).

Em 1990, firma-se o Acordo de Complementação Econômica, que decidiu a formação de um mercado comum entre Brasil e Argentina com base em reduções tarifárias generalizadas. Com o Tratado de Assumpção, em 1991, que criou o Mercosul. o comércio de arroz entre todos os países membros (Uruguai, Paraguai, Brasil e Argentina) passou a ser livre com alíquota zero de imposto de importação.

Entretanto. apesar das tarifas de importação do arroz serem nulas há algum tempo, no início da década e até meados de 1992, os preços dos produtos originários da Argentina e Uruguai permaneciam em níveis substancialmente superiores aos dos demais fornecedores. Após 1994, os preços da Argentina e do Uruguai caem a níveis praticamente iguais aos demais fornecedores, cujos diferenciais estão ilustrados na figura 7.

Desta forma. Argentina e Uruguai conseguiram aumentar expressivamente suas participações na composição da demanda brasileira por importações. Conjuntamente. aumentaram suas participações de 49\% em 1991 para quase $92 \%$ em 1997. Por outro lado, reduzem-se as participações dos países asiáticos e dos Estados Unidos na composição da demanda das importações brasileiras de arroz. A participação do arroz de origem americana no total importado pelo Brasil passa de 68,4\% em 1991(David e Nonnenberg) para 26\% em 1994 e para 4\% em 1997, como mostra o quadro 7 . 

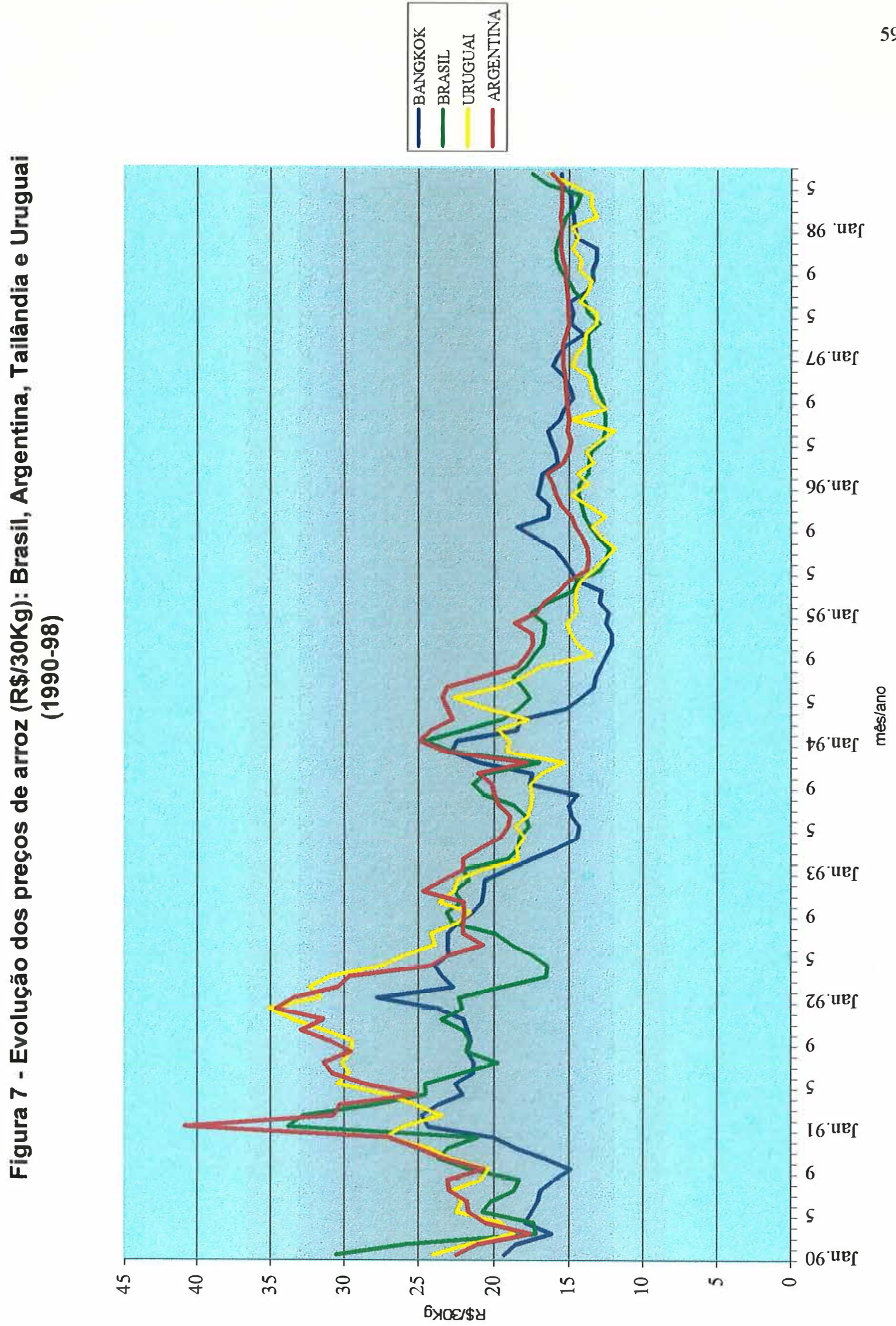

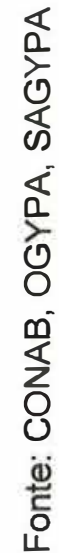


Quadro 7 - Importações brasileiras de arroz (branqueado) por país de origem (mil toneladas).

\begin{tabular}{|c|c|c|c|c|c|c|c|c|c|c|}
\hline \multirow[b]{2}{*}{ País } & \multicolumn{2}{|c|}{1994} & \multicolumn{2}{|c|}{1995} & \multicolumn{2}{|c|}{1996} & \multicolumn{2}{|c|}{1997} & \multicolumn{2}{|c|}{$1998^{1 /}$} \\
\hline & $\begin{array}{l}\text { volume } \\
(1000 t .)\end{array}$ & $\begin{array}{l}\text { \% sobre } \\
\text { total - }\end{array}$ & $\begin{array}{l}\text { Volume } \\
(1000 \mathrm{t} .)\end{array}$ & $\begin{array}{c}\text { \% sobre } \\
\text { total }\end{array}$ & $\begin{array}{l}\text { volume } \\
\text { (1000 t.) }\end{array}$ & $\begin{array}{c}\text { \% sobre } \\
\text { total }\end{array}$ & $\begin{array}{l}\text { volume } \\
(1000 \mathrm{t} .)\end{array}$ & $\begin{array}{c}\% \text { sobre } \\
\text { total }\end{array}$ & $\begin{array}{l}\text { volume } \\
\text { (1000 t.) }\end{array}$ & $\begin{array}{c}\text { \% sobre } \\
\text { total }\end{array}$ \\
\hline Argentina & 143,69 & 20,20 & 266,02 & 48,38 & 221,85 & 40,19 & 226,51 & 42,66 & 229,09 & 32,21 \\
\hline Uruguai & 206,88 & 29,09 & 159,63 & 29,03 & 258,67 & 46,86 & 260,51 & 49,06 & 281,92 & 39,64 \\
\hline EUA & 190,41 & 26,77 & 51,89 & 9,44 & 69,48 & 12,59 & 25,30 & 4,77 & 18,39 & 2,59 \\
\hline Total & 711,28 & & 549,80 & & 552,00 & & 530,95 & & 711,27 & \\
\hline
\end{tabular}

Fonte: CONAB.

" - De janeiro a novembro.

O segmento produtivo nacional tem se deparado com perda de competitividade frente aos orizicultores da Argentina e do Uruguai. Estes países possuem boa vocação para o cultivo de arroz; suas vantagens comparativas estão associadas à existência de solos ricos em matéria orgânica, localizados em grandes extensões de áreas contínuas e planas (os pampas úmidos), o que implica em menores requerimentos de fertilizantes e herbicidas, além de terem menores custos de arrendamento, preço da terra e menor incidência de encargos fiscais e financeiros sobre a produção (Aló e Manduca, 1998). Tais vantagens se traduzem em melhores níveis de produtividade (figura 8) e consideráveis diferenciais de custo de produção, relativamente ao custo brasileiro. 


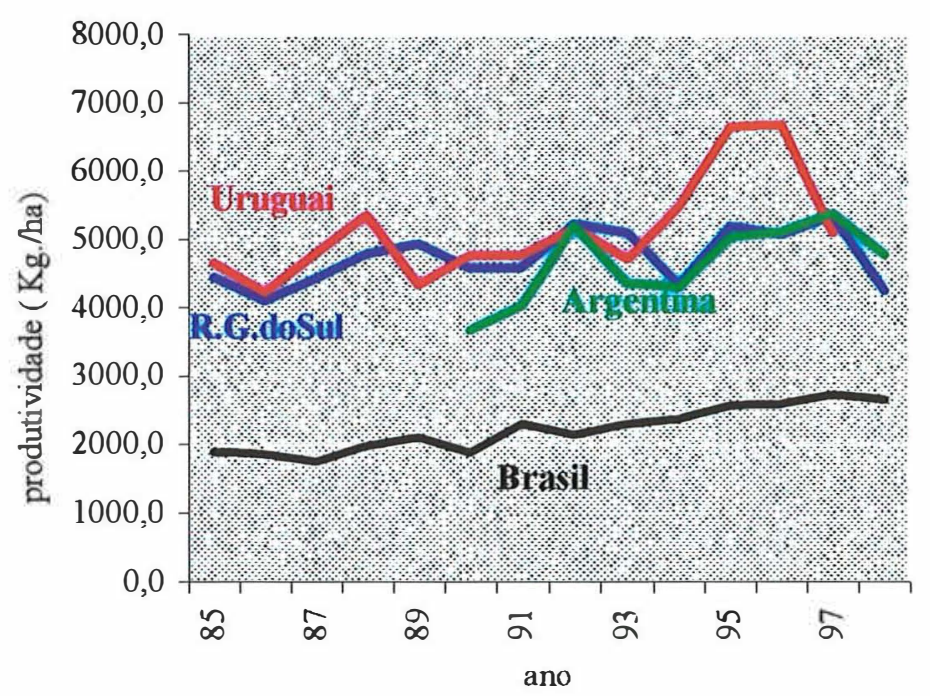

Fonte: CONAB, SAGYPA, OGYPA ${ }^{40}$.

Figura 8 - Evolução das produtividades de arroz: Brasil (média nacional e Estado do Rio Grande do Sul), Argentina e Uruguai1985- 1998.

De fato, David e Nonnenberg (1997) calcularam a evolução das Vantagens Comparativas Reveladas ${ }^{41}$ e indicam que o arroz está entre os produtos em que o Brasil perde vantagens comparativas no período 1992/94. Os mesmos indicadores para a Argentina e Uruguai mostram expressivo crescimento, revelando que as exportações originárias destes dois países elevaram-se mais do que a média das exportações mundiais e mais do que a média das exportações totais de cada país. Para os autores, isto nitidamente revela uma trajetória de especialização. Também estaria

\footnotetext{
${ }^{40}$ OGYPA (Oficina de Programácion y Politica Agricola - Ministério de Ganaderia, Agricultura y Pesca do Uruguai), SAGYPA (Secretaria da Agricultura, Ganaderia, Pesca y Alimentacion - Ministério de Economia, Obras e Serviços Públicos da Argentina)

${ }^{41}$ Este indicador pode tomar a forma de participação do saldo comercial de um determinado produto no PIB do país ou, a participação do saldo comercial do produto no saldo comercial do país.
} 
indicando que o deslocamento das importaçōes brasileiras de arroz de terceiros mercados em favor do produto originário daqueles países, estaria mais associada ao aumento de competitividade dos mesmos do que propriamente à implantação do Mercosul.

Além da questão da acomodação à maior competição com os parceiros do Mercosul, esta perda de competitividade da produção arrozeira nacional está associada ao esgotamento do sistema de plantio que antecede as pastagens, aos riscos inerentes à instabilidade climática, agravados pelo baixo nível de adoção das tecnologias recomendadas e pela baixa aceitação do tipo de grão produzido pelos cultivos de sequeiro $^{42}$.

A oferta nacional de arroz é oriunda de 3 sistemas de produção. O sistema de várzeas, que participa com 30\% da área plantada e produz $60 \%$ da produção nacional; o sistema de terras altas com $66 \%$ da área e produz cerca de $37 \%$ da produção nacional e, por último, o sistema de várzea úmida, que envolve uma área de 3,4\%, correspondendo a $2,5 \%$ da produção nacional ${ }^{43}$.

No sistema de várzeas, o Estado do Rio Grande do Sul é o maior produtor, tendo produzido cerca de $74 \%$ da produção nacional sob este sistema, na safra 1996/97, segundo Guimarães, el al. (1998). No sistema de várzea úmida, destaca-se o Estado de Minas Gerais, contribuindo com cerca de $93 \%$ desta produção, segundo aqueles autores.

O sistema de arroz de terras altas envolve o plantio de subsistência, comum nas regiões Norte e Nordeste, o plantio de transição, designado como aquele que precede ao plantio de pastagens, comum na região Centro-Oeste e o plantio comercial nas terras já cultivadas, predominante nas regiões Sul e Sudeste. Nos anos 90, a área plantada neste sistema tem diminuído (Guimarães, 1998), o que contribui para explicar os movimentos de significativas quedas na produção de arroz no Brasil a partir de 1995.

\footnotetext{
42 Sobre este último aspecto, atualmente existem variedades de boa qualidade, com classificaçāo comercial semelhante ao do agulhinha, oferecendo boas perspectivas de competitividade.

${ }^{43}$ Estes dados são da safra 1996/97 e estão apresentados em Guimarães et al. (1998).
} 
A área colhida na média dos anos $1987 / 89$ e 1996/98 passa de 5,7 milhões para 3,5 milhões de hectares, uma redução na área colhida de $38 \%$, com queda na produção entre a média dos dois períodos correspondente a $13 \%$. Entretanto, os ganhos de produtividade contribuíram para amortecer a redução da produção, como se pode evidenciar na figura 9 abaixo .

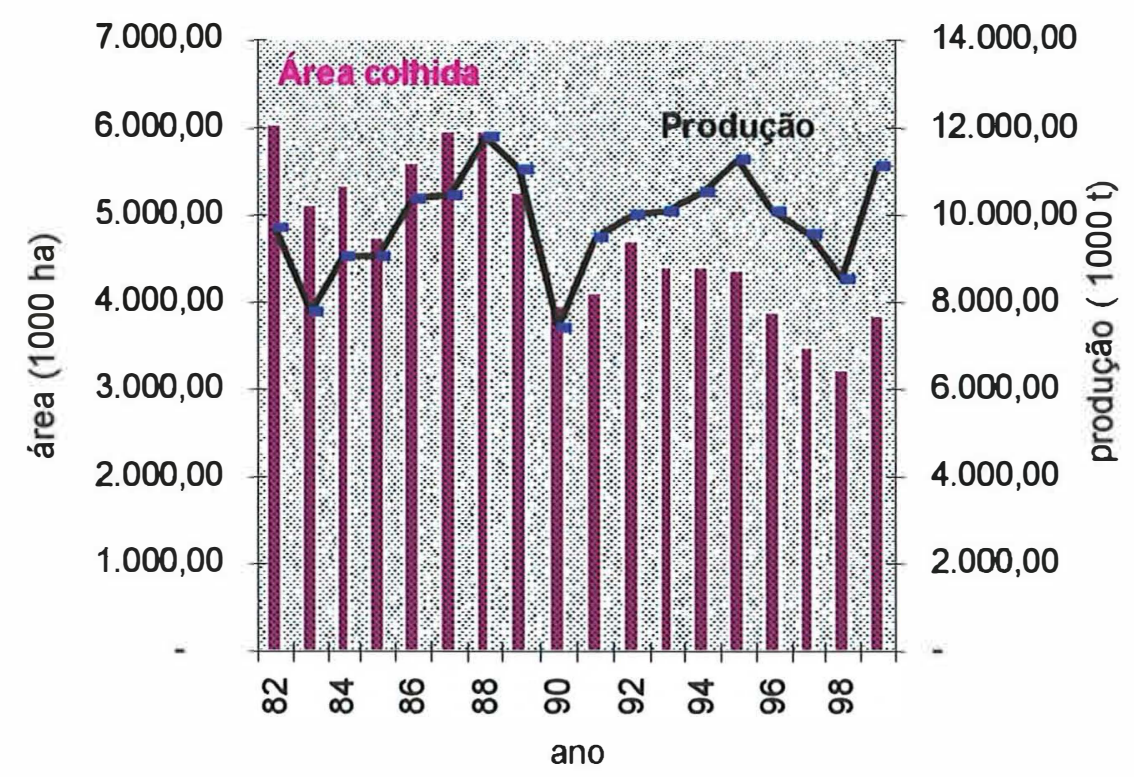

Fonte: CONAB.

Figura 9 - Evolução da área e produtividade de arroz no Brasil, 1982 - 1998.

A figura 10 mostra a evolução da área colhida e produção do arroz no Estado do Rio Grande do Sul, o qual foi destacado em função de sua importância na produção nacional pelas diferentes características do arroz irrigado. Em conformidade com a tendência observada para o Brasil como um todo, o Rio Grande do Sul apresenta reduções na área cultivada e produção, embora menos acentuadas e somente a partir de 1995. 
O arroz irrigado cultivado no Rio Grande do Sul caracteriza-se pelo menor risco associado ao cultivo, estabilidade produtiva e altos níveis de produtividade, comparáveis às do Unuguai e Argentina, como está evidenciado na figura 8 (página 61).

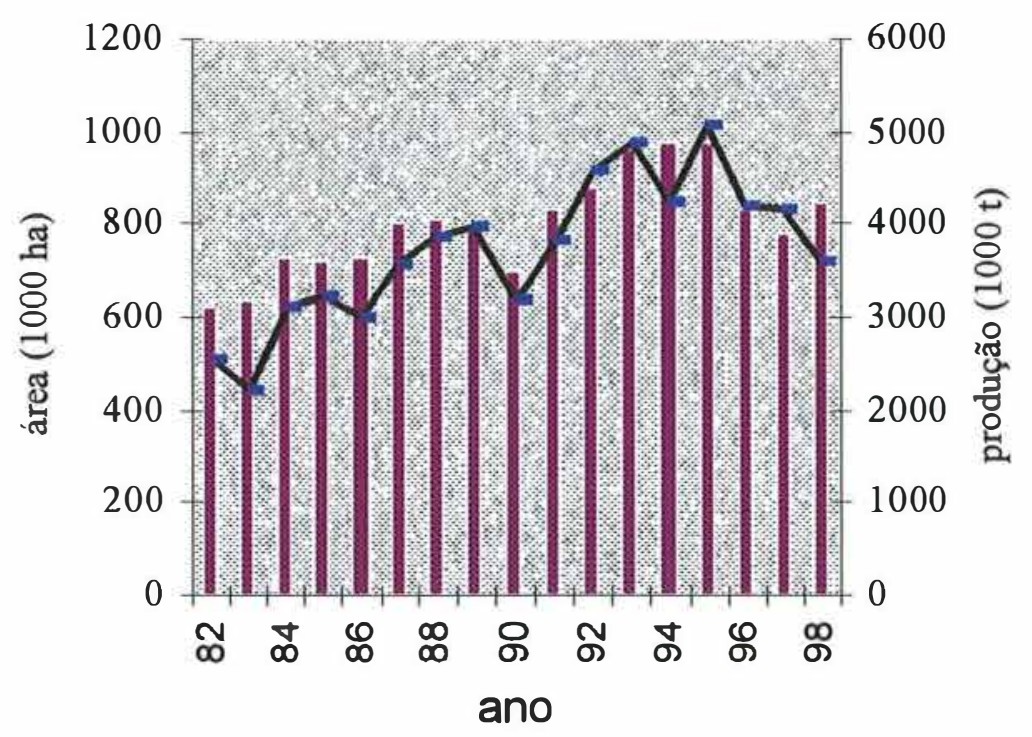

Fonte: CONAB.

Figura 10 - Evolução da produção e produtividade do arroz no Estado do Rio Grande do Sul, 1982 - 1998.

Enquanto a produtividade média do país tem permanecido em torno de $2.500 \mathrm{Kg}$ por hectare, o Rio Grande do Sul mantém um patamar muito próximo aos níveis de produtividade da Argentina, tendo alcançado mais de $4.500 \mathrm{~kg}$ por hectare em vários anos. O Uruguai destaca-se, em alguns anos com significativos diferenciais de produtividade, atingindo mais de $6.500 \mathrm{~kg}$. por hectare em 1995 e 1996 (figura 8 página $61)$.

A redução na capacidade de auto-suficiência no abastecimento interno do Brasil encontra-se evidenciada no quadro 8 onde se vê que a relação produção/consumo 
cai de 1,06 na média das safras 86/87-88/89 para 0,80 na média das safras 95/96-97/98 (coluna 6). Da mesma forma, cresce a participação das importaçōes no consumo interno (coluna 7), mostrando que, no caso do arroz, o país de fato torna-se dependente destas para abastecer o mercado interno.

\section{Quadro 8 - Quadro de suprimento anual de arroz em casca (mil toneladas).}

\begin{tabular}{|c|c|c|c|c|c|c|c|}
\hline $\begin{array}{l}\text { Ano/ } \\
\text { Safra }\end{array}$ & Produção & Importação & $\begin{array}{c}\begin{array}{c}\text { Consu- } \\
\text { mo }\end{array} \\
(3) \\
\end{array}$ & $\begin{array}{l}\text { Exporta- } \\
\text { ção } \\
(4) \\
\end{array}$ & $\begin{array}{l}\text { Estoque de } \\
\text { passagem } \\
(5) \\
\end{array}$ & $\begin{array}{l}\text { Produção/ } \\
\text { Consumo } \\
\text { (6) }\end{array}$ & $\begin{array}{c}\text { Importaçāo/ } \\
\text { Consumo } \\
(7) \\
\end{array}$ \\
\hline $82 / 83$ & $8.224,0$ & 465,0 & $9.150,0$ & 12,0 & 572,2 & 0,90 & 5,0 \\
\hline $83 / 84$ & $8.991,0$ & 91,0 & $9.200,0$ & 2,0 & 452,2 & 0,98 & 1,0 \\
\hline $84 / 85$ & $8.760,0$ & 500,0 & $9.660,0$ & 5,0 & 47,2 & 0,94 & 5,2 \\
\hline $85 / 86$ & $9.813,0$ & $2.074,0$ & $10.240,0$ & 6,0 & $1.688,2$ & 0,96 & 20,2 \\
\hline $86 / 87$ & $10.578,0$ & 235,0 & $10.000,0$ & 5,0 & $2.496,2$ & 1,05 & 2,3 \\
\hline $87 / 88$ & $11.762,2$ & 190,0 & $10.500,0$ & 10,0 & $3.938,4$ & 1,12 & 1,8 \\
\hline $88 / 89$ & 11.092 .0 & 252,5 & $10.800,0$ & 10,0 & $4.472,9$ & 1,03 & 2,3 \\
\hline $89 / 90$ & $7.967,6$ & 717,6 & $11.000,0$ & 10,8 & $2.147,3$ & 0,72 & 6,5 \\
\hline $90 / 91$ & $9.996,8$ & $1.296,6$ & $11.220,0$ & 2,1 & $2.218,6$ & 0,89 & 11,4 \\
\hline $91 / 92$ & 10.102 .8 & 732,3 & $11.332,2$ & 5,1 & $1.716,4$ & 0,89 & 6,5 \\
\hline $92 / 93$ & $9.902,8$ & 880,9 & $11.445,5$ & 5,7 & $1.048,9$ & 0,86 & 7,7 \\
\hline $93 / 94$ & 10.522 .8 & $1.565,5$ & $11.560,0$ & 3,9 & $1.573,3$ & 0,91 & 13,5 \\
\hline $94 / 95$ & $11.237,3$ & 978,6 & $11.617,8$ & 34,7 & $2.136,7$ & 0,97 & 8,4 \\
\hline $95 / 96$ & $10.037,0$ & 977,0 & $11.630,0$ & 5,0 & $1.840,3$ & 0,86 & 8,4 \\
\hline $96 / 97$ & $9.524,0$ & $1.223,00$ & 11664,0 & 3,0 & 1377,0 & 0.81 & 10,5 \\
\hline $97 / 98$ & $8.511,0$ & $2.000,00$ & 11694,0 & 2,0 & 221,0 & 0.73 & 17,1 \\
\hline $98 / 99^{*}$ & 11.289 & $1.000,00$ & 11.669 .0 & 30,0 & 781,0 & 0,96 & 8,6 \\
\hline
\end{tabular}

Estimativa.

Fonte: Companhia Nacional de Abastecimento ( CONAB).

As tendências atuais mostram que o Mercosul é auto-suficiente no abastecimento de arroz, e, portanto os parceiros do Brasil neste mercado deverão continuar sendo os principais supridores do arroz importado do país. Para Aló e Manduca (1998), o ponto característico da comercialização de arroz no Mercosul é o fato de não ser possível analisar isoladamente um país membro, sem considerar os demais, para que se possa tirar conclusões satisfatórias. Como o comércio entre os 
países é livre, o mercado orienta-se pelos níveis globais de estoques de passagem, produção e consumo total.

\subsection{O mercado de milho}

O milho é um dos cereais que maior número de produtos industrializados apresenta, e por isso movimenta grandes complexos agroindustriais voltados tanto para a alimentação humana quanto e especialmente para a alimentação animal, constituindo matéria prima básica para a avicultura, suinocultura e bovinocultura de leite.

No cenário internacional, de uma oferta mundial estimada para a safra 1998/99 da ordem de 595 milhões de toneladas, o Brasil se mantém na terceira posição entre os maiores produtores, ofertando um volume estimado equivalente a 35 milhões de toneladas na mesma safra. Os Estados Unidos são os maiores produtores (243 milhões de toneladas) e exportadores, participando com cerca de $46 \%$ das exportações totais $^{44}$.

A Argentina é, praticamente, o único país exportador do Mercosul, e também o segundo maior exportador e quarto maior produtor no mercado mundial. $\mathrm{O}$ volume de suas exportações alcançou expressivo crescimento nesta década, prevendo-se para a safra 1998/99, uma participação em torno de $18 \%$ das exportações mundiais ${ }^{45}$.

No Brasil, o cultivo do milho encontra-se bastante disperso no território nacional, mas é na região Centro-Sul que a produção encontra-se mais concentrada e as lavouras são conduzidas com melhores níveis tecnológicos. Nesta região, a oferta de milho está condicionada à rentabilidade das culturas competitivas por área e pelos mesmos fatores de produção, principalmente soja e algodão. Na região Nordeste tal concorrência não ocorre, entretanto, predomina no plantio do milho tecnologia rudimentar, com baixa utilização de insumos e sementes híbridas.

Em consequiência deste perfil produtivo, os níveis de produtividade obtidos na região Centro-Sul são bastante distintos da média do país. Na safra de 1998,

\footnotetext{
${ }^{44}$ Estimativas apontadas por Agrianual 1999.

${ }^{45}$ Agrianual, 1999.
} 
enquanto a média brasileira esteve em torno de $2.500 \mathrm{~kg} / \mathrm{ha}$, a região Centro-Sul ultrapassou $3.600 \mathrm{~kg}$ por hectare. Isto está evidenciado na figura 11, que mostra também a evolução da produtividade para a Argentina, Estados Unidos e Paraguai, principais ofertantes na composição das importações brasileiras de milho.

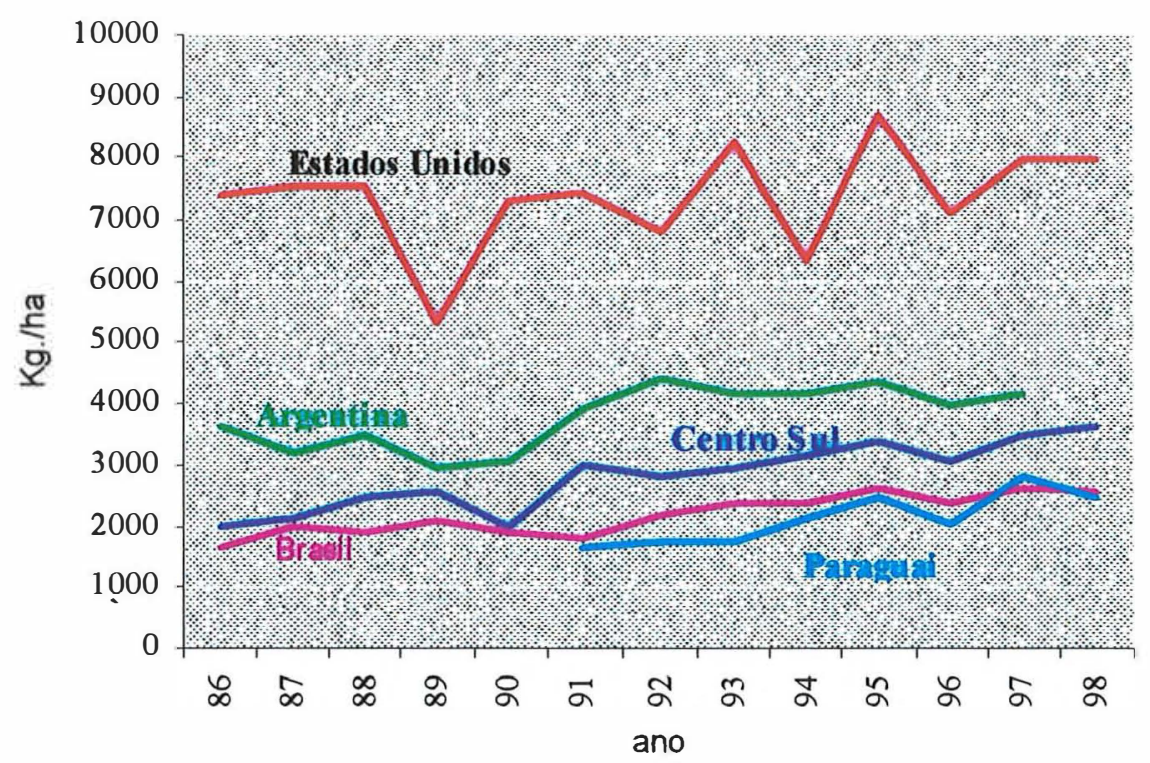

Fonte: USDA, CONAB, Banco Central do Paraguai.

Figura 11 - Evolução das produtividades de milho: Estados Unidos, Paraguai, Argentina e Brasil (média do país e região Centro-Sul), 1986 a 1996.

David e Nonnenberg (1997) constataram empiricamente perda de vantagens comparativas na produção de milho entre o final da década passada até meados desta, enquanto a Argentina, ao contrário, teria ganho vantagens comparativas no mesmo período. De fato, este país possui condições de solo e luminosidade mais vantajosas para a produção de milho do que o Brasil, do que resultam menores custos de produção. Jank e Lopes (1997) mostram, na comparação de custos de produção e preços 
de venda entre os países do Mercosul, que a Argentina é o país mais eficiente na produção de milho, seguido do Paraguai e Uruguai .

Um outro fator que também explica a perda de vantagens comparativas brasileiras na produção de milho diz respeito ao alto custo do frete da região CentroOeste para as regiões de produção animal intensiva do sul, sudeste e mesmo para abastecimento da região nordeste. Com a liberação das tarifas de importação e frete marítimo mais barato em relação ao frete rodoviário entre as regiões Centro-Sul e Nordeste do Brasil, a Argentina tornou-se o principal fornecedor para a região Nordeste brasileira.

Historicamente o milho é a cultura que concorre com maior área plantada no território nacional; somente na última safra (1997/98) a área deste cereal foi superada pela área de soja, resultado da substituição parcial da área no plantio, tendo sido a área plantada total de milho em torno de $12 \%$ menor que a da soja.

A evolução da área cultivada de milho nos anos noventa manteve-se estabilizada em torno de 1,4 milhões de hectares até 1998, quando cai para 1,2 milhões de hectares, enquanto a produção apresentou uma tendência claramente crescente até 1995, seguida de um certo recuo até 1998 (figura 12).

O Brasil perdeu as características de auto-suficiência na produção de milho no final dos anos setenta, ocasião até a qual o país gerava excedentes para exportação. Desde então os desvios de eficácia das políticas de crédito e de preços mínimos ${ }^{46}$; assim como a acentuada intervenção governamental no mercado de estoques $^{+7}$ que vigorou nos anos oitenta explicam parcialmente a redução no nível de auto-suficiência e o aumento das importações nesta década. Desta forma, o país perde a

\footnotetext{
${ }^{46} \mathrm{O}$ milho, seguido do arroz são os produtos que apresentam as maiores participações na pauta da política de preços mínimos. portanto, a área plantada e os níveis tecnológicos adotados são sensíveis aos estímulos oferecidos pela política de preços.

47 Antes da década dos 90 , historicamente os mercados de arroz e milho representaram alvos de sistemáticas intervençōes estatais diretas (tabelamentos de preços) e indiretas (políticas de preços, comercialização, abastecimento, etc), fazendo com que a condução de seus preços seguissem um comportamento diferente daquele que se configurava nos mercados internacionais. Nesta década, as evidências são de que o conjunto de fatores que conduziram a liberalização comercial (discutidos no capítulo anterior) permitiram que os vetores de preços externos possivelmente estejam servindo de referência para a formação dos preços internos.
} 


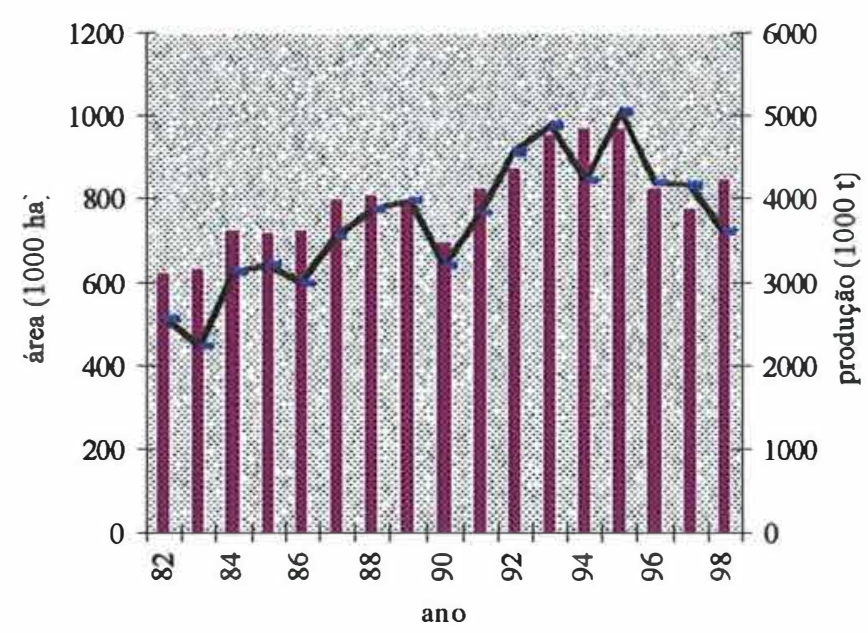

Fonte: CONAB.

Figura 12 - Evolução da área colhida e produção de milho no Brasil. 1982 a 1998.

capacidade de atender ao consumo interno, entre 1988 e 1998, o coeficiente de autosuficiência médio (relação produção/consumo) da quadro 9 mantém-se em torno de 0,96.

Os principais países provedores de milho para o mercado brasileiro estão relacionados na quadro 10 abaixo. Um fato novo no Mercosul é que o Paraguai, que virtualmente não exportava para o Brasil, torna-se responsável por cerca de $9 \%$ das importações brasileiras entre 1994 e 1997. De fato, na figura 13 (página 71), que mostra a evolução dos preços internos e externos (posto no Brasil) de milho, pode-se verificar que os preços deste país caem aos níveis dos preços do Brasil e da Argentina a partir de 1994.

A Argentina destaca-se como o principal fornecedor, com uma participacão sobre o total das importações brasileiras, naquele período, em torno de $41 \%$ e $89 \%$ em 1998. A participação de outros fornecedores, como Estados Unidos e União Européia diminuiu consideravelmente, com a consolidação do Mercosul. 
Quadro 9 - Quadro de suprimento anual de milho em grãos (mil toneladas).

\begin{tabular}{|cccccccc|}
\hline $\begin{array}{c}\text { Ano/ } \\
\text { Safra }\end{array}$ & Produçāo & Importação & Consumo & Exportação & $\begin{array}{c}\text { Estoque de } \\
\text { Passagem }\end{array}$ & $\begin{array}{c}\text { Produção/ } \\
\text { Consumo }\end{array}$ & $\begin{array}{c}\text { Importação/ } \\
\text { consumo } \\
{\left[(2) /(3)^{*} 100\right]} \\
(7)\end{array}$ \\
\hline $82 / 83$ & $19.014,1$ & 213,1 & $19.461,2$ & 765,9 & 823,5 & 0,98 & 1,1 \\
$83 / 84$ & $21.177,5$ & 253,6 & $19.955,4$ & 178,2 & $2.121,0$ & 1,06 & 1,3 \\
$84 / 85$ & $21.173,9$ & 262,1 & $22.957,0$ & - & 600,0 & 0,92 & 1,1 \\
$85 / 86$ & $20.264,2$ & $2,426,6$ & $21.687,6$ & - & $1.600,2$ & 0,93 & 11,2 \\
$86 / 87$ & $26.758,5$ & 871,2 & $26.350,2$ & - & $2.879,7$ & 1,02 & 3,3 \\
$87 / 88$ & $25.223,6$ & 15,0 & $25.320,0$ & - & $2.798,3$ & 0,97 & 0,0 \\
$88 / 89$ & $26.266,8$ & 154,9 & $26.140,0$ & - & $3.080,0$ & 1,00 & 0,6 \\
$89 / 90$ & $22.257,5$ & 700,0 & $24.800,0$ & - & $1.237,5$ & 0,90 & 2,8 \\
$90 / 91$ & $24.096,1$ & 832,2 & $25.288,0$ & - & 877,8 & 0,95 & 3,3 \\
$91 / 92$ & $30.771,2$ & 340,0 & $28.500,0$ & - & $3.489,0$ & 1,08 & 1,2 \\
$92 / 93$ & $29.207,4$ & $1.497,9$ & $30.775,0$ & - & $3.419,3$ & 0,95 & 4,8 \\
$93 / 94$ & $33.173,5$ & $1.568,6$ & $32.732,0$ & - & $5.429,4$ & 1,01 & 4,8 \\
$94 / 95$ & $37.441,9$ & 984,1 & $36.447,0$ & - & $7.408,4$ & 1,02 & 2,7 \\
$95 / 96$ & $32.405,0$ & 377,0 & 35208,0 & 608,0 & 5961,5 & 0,88 & 1,1 \\
$96 / 97$ & $35.703,0$ & 500,0 & 35912,0 & 100,0 & $6.169,0$ & 0,99 & 1,4 \\
$97 / 98$ & $30.608,0$ & 1500,0 & 36451,0 & - & 1826,0 & 0.84 & 4,1 \\
$98 / 99{ }^{*}$ & 36617,0 & 1000,0 & 35000,0 & - & 1443,0 & 1,04 & 2,8 \\
\hline
\end{tabular}

Estimativa.

Fonte: Companhia Nacional de Abastecimento ( CONAB).

Quadro 10 - Importações brasileiras de milho por país de origem (mil toneladas) e participação de cada fornecedor sobre o total importado (\%).

\begin{tabular}{|c|c|c|c|c|c|c|c|c|c|c|}
\hline \multirow[b]{2}{*}{ País } & \multicolumn{2}{|c|}{1994} & \multicolumn{2}{|c|}{1995} & \multicolumn{2}{|c|}{1996} & \multicolumn{2}{|l|}{1997} & \multicolumn{2}{|c|}{1998} \\
\hline & Volume & $\begin{array}{c}\% \\
\text { sobre } \\
\text { total }\end{array}$ & volume & $\begin{array}{l}\% \\
\text { sobre } \\
\text { total }\end{array}$ & Volume & $\begin{array}{c}\% \\
\text { sobre } \\
\text { total }\end{array}$ & Volume & $\begin{array}{c}\% \\
\text { sobre } \\
\text { total }\end{array}$ & Volume & $\begin{array}{c}\% \\
\text { sobre } \\
\text { total }\end{array}$ \\
\hline Argentina & 962,1 & 70,0 & 720,6 & 52,4 & 185,1 & 13,5 & 400,0 & 29,1 & $1.592,9$ & 88,2 \\
\hline Paraguai & 86,0 & 6,2 & 174,8 & 12,7 & 125,1 & 9,1 & 125,2 & 9,1 & 122,6 & 6.7 \\
\hline Est. Unidos & 298,8 & 21,7 & 199,9 & 14,5 & 9,3 & 0,7 & 4,0 & 0,3 & 48,5 & 2,7 \\
\hline Total & $1.374,9$ & & $1.127,50$ & & 321,61 & & 532,46 & & 1806,8 & \\
\hline
\end{tabular}

Fonte: $\mathrm{CONAB}$. 
Figura 13 - Evolução dos Preços de milho: Brasil, Chicago (futuro, primeira entrega), Estados Unidos, Argentina e Paraguai, 1990 - 1998

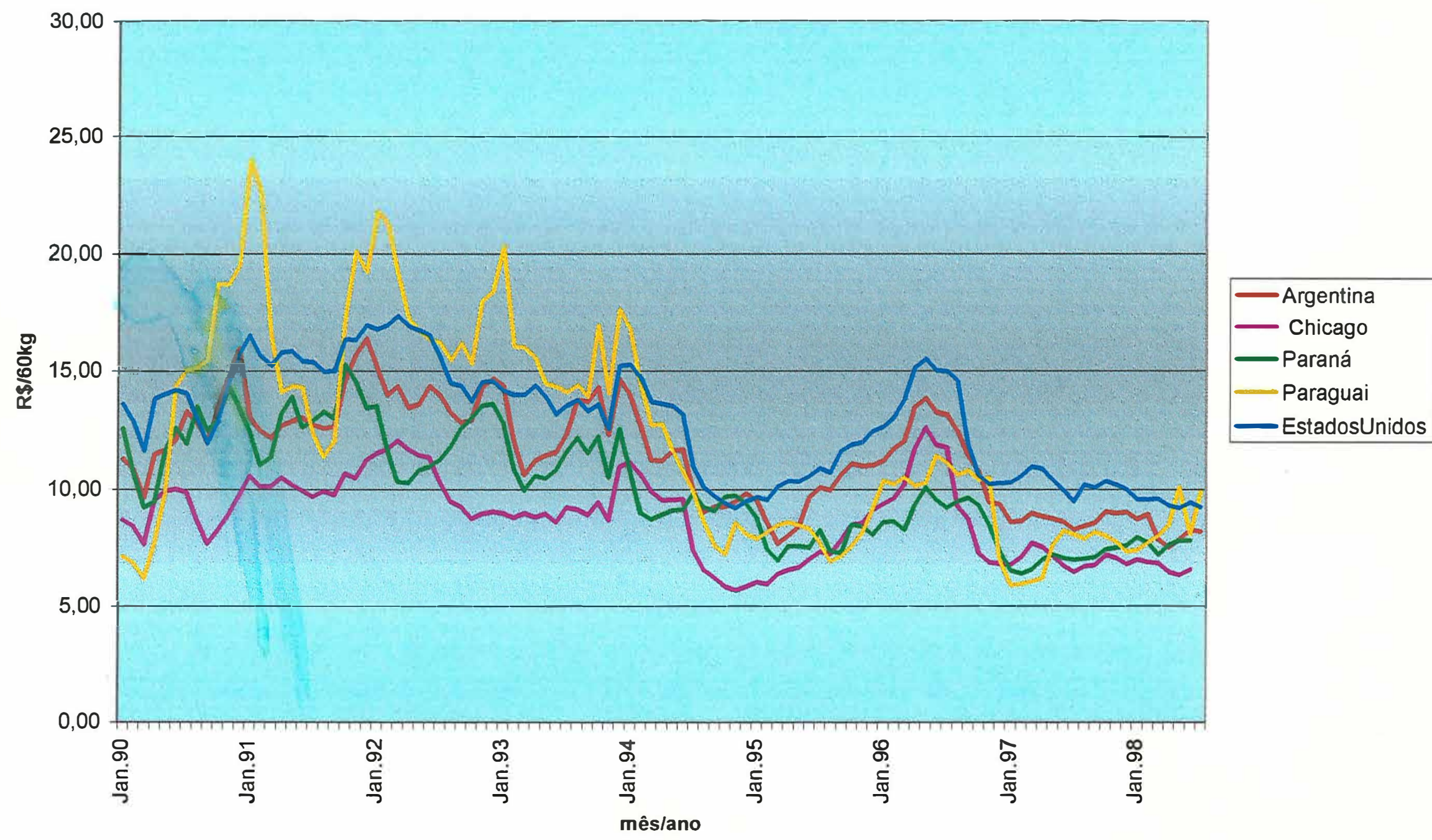




\section{METODOLOGIA}

Neste capítulo são apresentados os procedimentos econométricos que serão utilizados para testar a validade da Lei do Preço Único, segundo a expressão (6) e apresentar os dados a serem utilizados.

\subsection{Procedimentos}

Os procedimentos utilizados na análise empírica dividem-se em 3 segmentos: 1) testes de estacionariedade das séries temporais (consiste em aplicar testes de raiz unitária para verificar se as séries podem ser consideradas estacionárias); 2) determinação das relações de cointegração e; 3) testes de hipóteses sobre os parâmetros de longo prazo das relações de cointegração. A partir das relações de cointegração obtidas, estes testes possibilitam evidenciar em que medida os mercados participam da(s) relação(çōes) de cointegração, a sensibilidade de resposta destes a desequilíbrios de curto prazo nos demais, e em que medida cada mercado pode ser considerado perfeitamente integrado com outros mercados.

\subsubsection{Estacionariedade de séries de tempo e testes de raiz unitária}

Estacionariedade de séries temporais é uma importante propriedade associada ao processo gerador das séries, especialmente em análises que abordam relações de longo prazo ${ }^{48}$ entre séries de dados. Neste caso, recomenda-se proceder a distinção entre variáveis estacionárias e não-estacionárias.

\footnotetext{
${ }^{48}$ Em estados de equilibrio de longo prazo não há tendência inerente a mudança uma vez que forças econômicas se equilibram, enquanto no curto prazo ocorrem desvios.
} 
Variáveis cujas médias e variâncias mudam ao longo do tempo são qualificadas de não estacionárias ou variáveis que possuem raiz unitária. Séries temporais estacionárias caracterizam-se por apresentar média e variância constantes no tempo e o valor da covariância dependente apenas da defasagem entre os dois períodos. De forma mais sistemática, de acordo com a definição de Harris (1995) tem-se que um processo gerador de dados, $Y_{t}$, é estacionário quando este satisfaz as seguintes condições (Harris (1995, p. 14) :

1. Esperança $\left[Y_{t}\right]$ é constante para todo t;

2. Variància $\left[Y_{t}\right]$ é constante para todo $\mathrm{t} \mathrm{e}$

3. Covariância $\left[Y_{t}, Y_{t+n}\right]$ é constante para todo $t$

Segundo Johansen (1996), comumente variáveis econômicas exibem atributos de não estacionariedade; neste caso considera-se que a não estacionariedade pode ser removida por diferenças. Testar a ordem de integração de uma série (ou de uma variável em um determinado modelo), corresponde a determinar se a série é não estacionária e indicar o número de vezes que precisa ser diferenciada para tornar-se estacionária ${ }^{49}$.

Uma série é estacionária se sua ordem de integração é zero, I(0). Séries com ordem de integração positivas $[\mathrm{I}(1), \mathrm{I}(2), \ldots]$ exibem não estacionariedade. Dizer que uma série temporal é estacionária de ordem um, I(1), por exemplo, é equivalente a dizer-se que tal série exibe uma raiz unitária no processo gerador de seus dados e que precisa ser diferenciada uma vez para tornar-se estacionária. Generalizando, tem-se que, se uma série deve ser diferenciada $d$ vezes antes de tornar-se estacionária, então contém $d$ raízes unitárias a diz-se ser integrada de ordem $d$, denotado $I(d)$.

O uso de métodos clássicos de estimação, tais como Mínimos Quadrados Ordinários, para estimar relações entre variáveis com raiz unitária, pode conduzir ao problema de regressão espúria. Isto significa que, se a média e variância de variáveis com raiz unitária mudam ao longo do tempo, todas as estatísticas computadas no modelo

${ }^{49}$ Diferenças do tipo: $\left(x_{t}-x_{t-1}\right)$. 
de regressão, que também usam esta média e variância, também dependem do tempo, e portanto, falham na convergência para o verdadeiro valor quando o tamanho da amostra aumenta. Além disso testes convencionais serão seriamente viezados para rejeitar a hipótese nula de não relação entre variáveis dependentes e independentes (Bhaskara Rao, 1994, p.2 e Harris, 1995, p.5).

\subsubsection{Testes de raiz unitária}

Os testes de raiz unitária ou testes de estacionariedade são utilizados para indicar se determinada série de tempo exibe atributos de estacionariedade ou não estacionariedade (é estacionária ou não estacionária).

As estatísticas mais utilizadas na literatura para testar a existência de raízes unitárias são as desenvolvidas por Dickey e Fuller (1979, 1981), Phillips (1987) e Phillips e Perron (1988) ${ }^{50}$. Este estudo aborda as estatísticas desenvolvidas por Dickey e Fuller $(1979,1981)$ os quais serão reportados pela abreviatura DF. Dada a extensa literatura existente sobre o assunto $^{51}$ pretende-se aqui destacar de maneira sucinta as principais características dos testes.

O teste do tipo DF sobre a existência de raiz unitária em uma série $Y_{t}$, discutidos por Dickey e Fuller (1979) parte da estimação, por mínimos quadrados, dos seguintes modelos, os quais diferem entre si pelos elementos determinísticos que contêm:

$$
\begin{aligned}
& \Delta y_{t}=\alpha+\beta t+\gamma y_{t-1}+\varepsilon_{t} \\
& \Delta y_{t}=\alpha+\gamma y_{t-1}+\varepsilon_{t} \\
& \Delta y_{t}=\gamma y_{t-1}+\varepsilon_{t}
\end{aligned}
$$

\footnotetext{
${ }^{50}$ Conforme Harris (1995): Perron, P. Time Séries Regression with a Unit Root. Econometrica, 55: 227 301, 1987; e, Perron, P. Trends and randon walks in macroeconomic time series: Further evidence from a new approach, Journal of Economic Dynamics and Control, 12, 297-332, 1988.

${ }^{51}$ Para uma introdução ao tema pode-se ver Holden e Perman (1994), Harris (1995). Para uma revisão mais detalhada tem-se Hamilton (1994).
} 
onde $y_{t}$ denota a variável que está sendo testada e $\Delta$ denota o operador de diferença $\Delta y_{t}$ é a variável em primeira diferença $\left(\Delta \mathrm{y}_{\mathrm{t}}=\mathrm{y}_{\mathrm{t}}-\mathrm{y}_{\mathrm{t}-1}\right), \quad \alpha$ é uma constante, $T$ é uma tendência temporal determinística, e $\varepsilon_{\mathrm{t}} \sim$ iid $\left(0, \sigma^{2}\right)$, ou seja, o termo de erro é um ruído branco idêntica e independentemente distribuído.

A hipótese a ser testada é $\boldsymbol{H}: \boldsymbol{Y}_{\mathrm{t}}$ não é $\mathrm{I}(0)$, frente à hipótese alternativa $H_{a}: Y_{t}$ é I(0).

Além do termo de erro ser um ruído branco, o teste de DF parte de outros pressupostos restritivos, tais como: a série segue um processo $\operatorname{AR}(1)$ e, se existe autocorrelação dos resíduos, a inferência desenvolvida a partir de (7) será incorreta. Neste caso a solução proposta é a inclusão de defasagens em $\Delta \mathrm{y}_{\mathrm{t}}$ nas expressões de (7) de forma que capture a estrutura autoregressiva da variável dependente e elimine a autocorrelação dos resíduos. Assim, tomando como exemplo o modelo (I) de (7) tem-se:

$$
\begin{gathered}
\Delta y_{t}=\alpha+\beta t+\gamma y_{t-1}+\sum_{i=1}^{k-1} \gamma_{i} \Delta y_{t-i}+\varepsilon_{t} \\
\gamma=\sum_{i=1}^{k} \rho_{i}-1 \quad \text { e } \quad \gamma_{i}=\sum_{j=i+1}^{k} \rho_{j}
\end{gathered}
$$

com

onde $\mathrm{k}$ é a ordem do processo autoregressivo que descreve o comportamento da série temporal e $\rho$ é a raiz associada à variável dependente defasada ${ }^{52}$. Este é o mais popular dos procedimentos e recebe a denominação genérica de teste de Dickey Fuller Aumentado (DFA).

A eleição do modelo que mais se aproxima do verdadeiro processo gerador dos dados em geral é fundamentada em uma estratégia de testes definida como procedimento sequiencial de Perron $(1988)^{53}$, cujas formulações estão apresentadas no quadro 11. Neste encontram-se várias estatísticas para testes de hipóteses, individuais ou

\footnotetext{
$52 \mathrm{Se}$, por exemplo, $Y_{t}$ for gerado por um processo autoregressivo $Y_{t}=\rho Y_{t-1}+e_{t}$, se $\rho$ pertencer ao intervalo $(-1,1)$ ou $|\rho|<1$ e os erros caracterizarem-se como ruídos brancos, então a série é integrada de ordem zero $\mathrm{I}(0)$.

${ }^{53}$ Conforme Harris (1995), Perron, P. A citação encontra-se na nota de rodapé 50.
} 
conjuntas, sobre a significância dos elementos determinísticos e sobre a existência de raízes unitárias.

O procedimento usual propõe que se comece o teste com o modelo mais amplo, contendo constante e tendência [como o modelo (I) em (7)], fazendo uso das estatísticas $\tau_{\tau}$ e $\phi_{3}$, passando-se seqüencialmente para especificações mais restritas nos modelos subseqüentes (modelo II e, em último caso, o modelo III) à medida que os resultados das estatísticas dos testes de hipóteses associados ao coeficiente da variável $y_{\mathrm{t}-1}$ forem não significativos. A ordem de integração (e o modelo associado ao processo gerador dos dados) é encontrada quando se puder rejeitar a hipótese de nulidade para o coeficiente da variável $y_{\mathrm{t}-1}$, em ajustamentos sucessivos nos quais aumenta-se o número de diferenças incluídas nas equações do quadro 11 e diminui-se de um o número de defasagens consideradas.

No quadro 11 a seguir, $\Delta \mathrm{y}_{\mathrm{t}-\mathrm{i}}$ é a primeira diferença da variável y defasada de um período $\left(\Delta \mathrm{y}_{\mathrm{t}-\mathrm{i}}=\mathrm{y}_{\mathrm{t}-\mathrm{i}}-\mathrm{y}_{\mathrm{t}-\mathrm{i}-\mathrm{i}}\right) ; \alpha, \beta, \gamma_{0}$ e $\gamma_{\mathrm{i}}$ são parâmetros a serem estimados.

Deve-se observar que se considerarmos o modelo original (não reparametrizado) tal como:

$$
Y_{t}=\alpha+\beta t+\rho Y_{t-1}+e_{t} \quad \mathrm{t}=1,2 \ldots
$$

e reparametrizando ${ }^{54}$ (9) por subtrair $Y_{t-1}$ de ambos os lados da equação ${ }^{55}$ :

$$
\Delta Y_{t}=\alpha+\beta t+(\rho-1) Y_{t-1}+e_{t}=\alpha+\beta t+\gamma_{0} Y_{t-1}+e_{t}
$$

tem-se que, testar em Ia (no quadro 11) $H_{0}: \gamma=0$ equivale a testar $H_{0}:(\rho-1)=0$ ou $\rho=1$ em (10). O mesmo raciocínio é valido para IIa e IIIa, excluindo-se respectivamente o termo de tendência e os termos de tendência e constante.

\footnotetext{
${ }^{54}$ A reparametrizaçāo consiste em tomar a variável dependente do processo auto-regressivo em primeira diferença.

55 Esta discussão encontra-se em Holden e Perman (1994, p. 56).
} 
Em (Ib) a hipótese nula apresentada no quadro 11 é equivalente a testar, a partir do modelo original (9) a hipótese conjunta : $(\alpha, \beta, \rho)=(\alpha, 0,1)$, ou seja, a estatística $\phi_{3}$ provê verificação para a hipótese conjunta que a série tem uma raiz unitária $(\rho=1)$ com possível termo de intercepto $(\alpha)$ e sem tendência $(\beta=0)$.

\section{Quadro 11 - Seqüência para testes de raiz unitária DFA.}

$(\text { Ia })^{\prime \prime} \quad \Delta y_{t}=\alpha+\beta t+\gamma y_{t-1}+\sum_{i=1}^{k-l} \gamma_{i} \Delta y_{t-i}+\varepsilon_{t}$

(Ib) $\Delta y_{t}=\alpha+\beta t+\gamma y_{t-1}+\sum_{i=1}^{k-1} \gamma_{i} \Delta y_{t-i}+\varepsilon_{t}$

$$
\gamma=\beta=0
$$

$\phi_{3}$

(Ic) $\Delta y_{t}=\alpha+\beta t+\gamma y_{t-1}+\sum_{i=1}^{k-1} \gamma_{i} \Delta y_{t-i}+\varepsilon_{t}$

$$
\beta=0
$$

$\tau_{\beta \tau}$

(Id) $\Delta y_{t}=\alpha+\beta t+\gamma y_{t-1}+\sum_{i=1}^{k-1} \gamma_{i} \Delta y_{t-i}+\varepsilon_{t}$

$$
\alpha=\beta=\gamma=0
$$

$\phi_{2}$

(IIa) $\Delta y_{t}=\alpha+\gamma y_{t-1}+\sum_{i=1}^{k-1} \gamma_{i} \Delta y_{t-i}+\varepsilon_{t}$

$$
\gamma=0
$$

(IIb) $\Delta \mathrm{y}_{\mathrm{t}}=\alpha+\gamma \mathrm{y}_{\mathrm{t}-1}+\sum_{\mathrm{i}=1}^{\mathrm{k}-1} \gamma_{\mathrm{i}} \Delta \mathrm{y}_{\mathrm{t}-\mathrm{i}}+\varepsilon_{\mathrm{t}}$

$$
\gamma=\alpha=0
$$

$\phi_{1}$

(IIc) $\Delta y_{t}=\alpha+\gamma y_{t-1}+\sum_{i=1}^{k-1} \gamma_{i} \Delta y_{t-i}+\varepsilon_{t}$

$$
\alpha=0
$$

$\tau_{\alpha \mu}$

(III) $\Delta y_{t}=\gamma y_{t-1}+\sum_{i=1}^{k-1} \gamma_{i} \Delta y_{t-i}+\varepsilon_{t}$

$$
\gamma=0
$$

Fonte: A partir de Harris (1995, p. 31 ) e Almeida (1998, p. 57).

I/ (Ia) a (Id) indicam tratar-se do mesmo modelo, variando apenas as hipóteses e os elementos a serem testados. O mesmo é válido para (IIa) a (IIc).

Nota: $O$ nome de cada teste estatístico é idêntico ao da sua representação. Por exemplo, o teste $\tau_{r}$ chamado tal tal. 
Caso se tenha constatado não rejeição da hipótese anterior, então a priori sabe-se que a série tem uma raiz unitária, sem tendência, mas com possível termo de intercepto. Para reafirmar esta conclusão utiliza-se a estatística $\tau_{\beta \tau}$ de (Ic), que é utilizada para testar se $\beta$ assume ser zero.

Já a hipótese conjunta (Id) é utilizada para testar, a partir do modelo original (9), a hipótese conjunta $(\alpha, \beta, \rho)=(0,0,1)$. Neste caso, dada a informação $a$ priori sobre a existência de raiz unitária e um termo de tendência no processo gerador dos dados, a estatística $\phi_{2}$ na realidade provê verificação para o termo de intercepto (Holden e Perman, 1994). Se $\phi_{2}$ conduzir a conclusão de que $\alpha$ é zero, então a série é um caminho aleatório sem termo de intercepto (drift). Do contrário, a série é um caminho aleatório com termo de intercepto.

Da mesma forma, as hipóteses apresentadas em IIa e Ib eqüivalem a testar, no modelo não reparametrizado e sem o termo constante [modelo (9) sem o termo $\alpha]$ respectivamente as hipóteses: $\rho=1$ e $(\alpha, \rho)=(0,1)$.

Os resultados sobre a presença de raiz unitária podem variar em função do número de diferenças defasadas a serem incluídas na equação, ou seja, o valor de $k$ nas equações do quadro 11 deve ser aquele que permita caracterizar o termo de erro da equação como ruído branco. Entre os procedimentos mais utilizados para determinar o valor de k estão os critérios de Akaike (AIC), Schwarz (SC) e Hannan-Quinn (HQ).

Segundo Luthekpohl $(1991)^{56}$, em Bacchi (1996), parte-se de uma especificação geral para equações tais como as especificadas no quadro 11, adotando-se, por exemplo, 12 defasagens da variável dependente para série de dados mensais, e faz-se ajustamentos sucessivos, tomando-se para inclusão no modelo o número de defasagens que resultar em menor valor para os critérios de AIC, SC, HQ.

O presente trabalho fará uso do critério de Akaike por ser amplamente utilizado. Tal critério é especificado como segue:

\footnotetext{
${ }^{56}$ LUTKEPOHL, H. Introduction to multiple time series. Berlin, Springer-Verlag, Heidelberg, 1993.
} 
Com $\hat{\sigma}^{2}$ sendo a soma dos quadrados dos resíduos das equações no quadro 11 dividido pelo número de observaçōes $(\mathrm{T})$.

\subsubsection{Testes de cointegração - O método de Johansen}

Cointegração, termo definido por Engle e Granger (1987) é entendido como uma técnica para estimar o equilíbrio ou parâmetros de longo prazo ${ }^{57}$ entre variáveis que apresentam raiz unitária (Bhaskara Rao, 1994, p.3). Dito de outra forma, o conceito de cointegração trata da existência de um equilíbrio para onde o sistema econômico converge ao longo do tempo e relaciona variáveis não estacionárias cuja combinação seja estacionária. Quando variáveis não estacionárias são cointegradas, existe uma direção onde uma relação de longo prazo significativa existe entre elas. A ausência de cointegração sugere que as variáveis não têm nenhuma ligação de longo prazo e podem ter comportamentos distintos uma da outra.

Tendo-se, por exemplo a seguinte combinação de longo prazo entre $P_{1}$ e $\mathrm{P}_{2}$, tal como expressa na equação (6) e transcrita abaixo:

$$
P_{1 t}=\mu+\beta P_{2 t}^{*}+\varepsilon_{t}
$$

\footnotetext{
${ }^{57}$ Um estado de equilibrio é definido como aquele no qual não há tendência inerente à mudança. Em geral, uma relação de equilîbrio é expressa através da função: $f(x 1, x 2, \ldots, x p)=0$, a qual descreve relações entre as $p$ variáveis quando o sistema está em equilíbrio. A expressão "equilíbrio de longo prazo" é usada para denotar a relação de equilíbrio para a qual o sistema converge ao longo do tempo. Dito de outra forma, uma relação de equilíbrio de longo prazo permite sistemáticos co-movimentos entre variáveis inseridas em um sistema econômico. Um exemplo de equação que representa tais co-movimentos é $x_{1}=\beta x_{2}$ para denotar relação de longo prazo linear entre $x_{1}$ e $x_{2}$ (Banerjee et al. 1993, p.2-3).
} 
Considerando que as duas séries de preços são integradas de ordem d, $I(d)$ e, se existir um vetor $\beta$ de forma que o termo de erro da regressão $\hat{\varepsilon}=\mathrm{P}_{1 t}-\mu-\hat{\delta} \mathrm{P}_{2 \mathrm{t}}$ for de menor ordem de integração, $I(d-b)$, onde $b>0$, então Engle e Granger (1987) definem $P_{l}$ e $P_{2}$ como cointegrados de ordem $(d, b)$. Por exemplo, se $P_{I t}$ e $P_{2 t}$ são ambas $I(I)$ e $\varepsilon_{t} \sim I(0)$, então as duas séries são cointegradas de ordem $(1,1)$.

O termo $\varepsilon_{t}$ é interpretado como um desvio do equilíbrio, isto é, a distância que o sistema está do sistema de equilíbrio de longo prazo em um ponto do tempo. Havendo uma relação de equilíbrio de longo prazo pode-se assumir que as variáveis movem-se juntas, que $\varepsilon_{\mathrm{t}}$ é estacionário e que as variáveis são cointegradas. Tal equilíbrio de longo prazo entre os preços de diferentes mercados é suficiente para indicar integração entre estes mercados (Williams e Bewley, 1993).

O método desenvolvido po Engle e Granger (1987), primeiro utilizado para indicar a existência de cointegração entre séries temporais, ultimamente tem sido considerado limitado pelas seguintes razões: (1) as relações de cointegração são restritas a um par de variáveis; (2) este teste requer que um dos preços seja exógeno (tomando como exemplo a abordagem deste estudo), e (3) o teste não tem limites de distribuição bem definidos, e, como resultado não provê procedimento de testes diretos segundo (Goodwin, (1992).

Resumindo, o método de Engle e Granger não é capaz de indicar mais do que uma relação de cointegração a ser determinada, sendo a relação de cointegração sensível à escolha da variável dependente. O método deve ser utilizado quando de fato existir um único vetor de cointegração e todas as variáveis colocadas do lado direito da equação forem exógenas (Harris, 1995). Quando se testa integração de mercados, assumir que um dos preços é exógeno pode ser incorreto: preços em dois países que comercializam entre si podem ser simultâneamente determinados, informações são divididas entre os países e os agentes podem operar em múltiplos mercados. Este problema é interpretado como sendo "um viés de simultaneidade" que pode confundir 
inferências estatísticas convencionais [Protopapadakis e Stoll (1983), Goodwin et al. (1990)].

O método proposto por Johansen (1988) e Johansen e Juselius (1990) não impõe a priori qual ou quais devem ser as variáveis endógenas no sistema, assumindo que todas as variáveis são endógenas simultaneamente e por isto é considerado apropriado para testar a presença de arbitragem de preços no mercado internacional (Goodwin, 1990 e 1992).

Supondo que um vetor $\mathbf{Z}_{\mathbf{t}}$ de $p$ variáveis $\mathbf{Z}_{\mathbf{t}}=\left(\mathbf{Z}_{\mathbf{1 t}}, \ldots \mathbf{Z}_{\mathrm{pt}}\right)$ potencialmente endógenas $^{58}$ seja gerado por um vetor autoregressivo (VAR) envolvendo $k$ defasagens de $\mathbf{Z}_{\mathbf{t}:}$

$$
Z_{t}=A_{1} Z_{t-1}+\ldots+A_{k} Z_{t-k}+\Psi D_{t}+\mu_{t}+\varepsilon_{t} \quad \mathrm{t}=1, \ldots, \mathrm{T}
$$

Onde:

- $Z_{t}$ é um $p x 1$ vetor coluna de variáveis estocásticas ${ }^{59}$ (não estacionárias), para o caso em que todas as variáveis contidas em $Z_{\mathbf{t}}$ são integradas de primeira ordem [I(1)], então $\Delta Z_{t}$ é um vetor de variáveis estacionárias [I(0)].

- $p_{t}$ é o número de variáveis supostamente endógenas. No caso do presente trabalho tomando-se o exemplo do modelo para as séries de milho, e supondo que todas as séries são não estacionárias e integradas de mesma ordem, tem-se

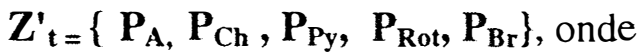

$$
\begin{aligned}
& \text { - } \mathrm{P}_{\mathrm{A}}=\text { preço Argentina/ Buenos Aires } \\
& \text { - } \quad P_{\mathrm{Ch}}=\text { preço Futuro Chicago primeira entrega } \\
& \text { - } \quad P_{P y}=\text { preço FOB Paraguai/ Assunção } \\
& \text { - } \mathrm{P}_{\mathrm{R}} \mathrm{Ot}=\text { preço Estados Unidos posto Roterdã } \\
& \text { - } \quad \mathrm{P}_{\mathrm{Br}}=\text { Preço Brasil }
\end{aligned}
$$

\footnotetext{
${ }_{59}^{58}$ Expressão utilizada por Harris (1995).

${ }^{59}$ Um processo estocástico é definido como um processo que evolui no tempo de acordo com leis probabilísticas. (Chatifield, 1996, p. 27).
} 
- $A_{i}$ são matrizes $p \times p$ de parâmetros

- $\mu_{t}$ representa o termo constante

- $\varepsilon_{\mathrm{t}}$ é um vetor $p \times 1$ de erros aleatórios niid $(0, \Sigma)$

- $\boldsymbol{D}_{\boldsymbol{t}}$ são variáveis são variáveis dummies que levam em conta choques de curto prazo e dummies sazonais que podem ser recomendadas no caso em que os dados apresentam periodicidade menor que anual .

Reescrevendo (12) na forma de um processo auto-regressivo de ordem $\mathrm{k}$ reparametrizado e expresso em forma matricial, tem-se a seguinte forma:

$$
\Delta Z_{t}=\Gamma_{1} \Delta Z_{t-1}+\ldots+\Gamma_{k-1} \Delta Z_{t-k+1}+\Pi_{Z_{t-k}}+\Psi D_{t}+\mu+\varepsilon_{t}
$$

Onde $\quad \Gamma \mathbf{i}=-\left(\mathbf{I}-\mathrm{A}_{1}-\ldots \mathrm{Ai}\right),(\mathrm{i}=1, \ldots, \mathrm{K}-1)$ e $\mathbf{I I}=-\left(\mathbf{I}-\mathbf{A}_{1}-\ldots-\mathbf{A k}\right)$. Esta forma de especificação do sistema contém informações sobre os ajustamentos de curto e longo prazos para mudanças em $Z_{t}$, via estimativas de $\Gamma \mathbf{i}$ e $\Pi_{\mathbf{i}}$ respectivamente (Harris, 1995, p.77).

A matriz II é de ordem $p \times p$ e embute informações sobre as relações de longo prazo entre as variáveis. Esta matriz é formada pelo produto das matrizes $\alpha$ e $\beta\left[\Pi=\alpha \beta^{\prime}\right]$, sendo $\alpha$ a velocidade de ajustamento a um dado desequilíbrio (também chamada de matriz de coeficientes de ajustamento ou de ponderações) enquanto $\beta$ é uma matriz de coeficientes de longo prazo e também chamada de matriz de cointegração. As matrizes $\alpha$ e $\beta$ têm ambas dimensões $p \times r$, onde $r$ é o número de relações de cointegração.

Neste contexto tem-se que, para que a expressão (13) seja estacionária é necessário que $\Pi \mathbf{Z}_{t-1}$ também o seja. A hipótese de cointegração é formulada em termos do $\operatorname{rank}$ ( $\mathrm{r}$ ) da matriz $\Pi$ (número de colunas linearmente independentes), definindo o número de vetores de cointegração existentes entre as variáveis contidas em $\mathbf{Z}_{\mathbf{t}}$.

Entre as $p$ variáveis do sistema é possível identificar 3 situações em termos da definição do rank de $\Pi$, sendo as duas primeiras situações casos extremos e a 
terceira trata da existência de vetores de cointegração e é de particular interesse para os propósitos desta pesquisa:

1. Se $r=p$, ou seja, o posto de $\Pi$ é igual ao número de variáveis, neste caso diz-se que a matriz $\Pi$ tem posto completo. Isto indica que $\mathbf{Z}_{\mathbf{t}}$ é um processo estacionário e o modelo com variáveis em nível seria mais apropriado para estimar as relações entre as variáveis do sistema;

2. Se $r=0$, indica que a matriz $\Pi$ é nula. Neste caso não existem relações de cointegração. Se (12) for I(1), então $\Delta Z_{t}$ (13) é estacionário e o modelo transformase em um VAR nas primeiras diferenças, e

3. Se $0<r<p$, ou seja, dado que $p$ é o número de variáveis no vetor $\mathbf{Z}_{\mathbf{t}}$, admite-se que $r<p$ seja o número de vetores distintos de cointegração entre as $p$ variáveis. Neste caso diz-se que a matriz $\Pi$ tem rank reduzido. Assim, entre as $p$ variáveis existirão $p$ - $r$ tendências estocásticas $^{60}$, sendo $p-1$ o número máximo de vetores de cointegração (as $r$ colunas de $\beta$, as quais representam as relações de equilíbrio estacionárias de longo prazo) distintos que podem existir entre as $p$ variáveis incluídas nọ sistema, os quais têm a propriedade de tornar o vetor $\beta^{\prime} \mathbf{Z}_{\mathbf{t}}$ estacionário $\left[\beta^{\prime} \mathbf{Z}_{\mathbf{t}} \sim \mathrm{I}(0)\right]$.

Exemplificando para o caso do milho no presente trabalho e supondo por simplicidade que todas as variáveis são integradas (têm raiz unitária de mesma ordem) e que $r=1$ e $k=1, \Pi Z_{t-1}$ adota a seguinte forma:

$$
\Pi \mathrm{Z}_{\mathrm{t}-1}=\alpha \beta \mathrm{Z}_{\mathrm{t}-1}=\left[\begin{array}{l}
\alpha_{A} \\
\alpha_{C h} \\
\alpha_{P y} \\
\alpha_{\text {Rot }} \\
\alpha_{\text {Brasil }}
\end{array}\right]\left[\beta_{A} \beta_{C h} \beta_{P y} \beta_{R o t} \beta_{\text {Brasil }}\right]\left[\begin{array}{l}
P_{A} \\
P_{C h} \\
P_{P y} \\
P_{R o t} \\
P_{\text {Brasil }}
\end{array}\right]
$$

${ }^{60}$ Processo estocástico está definido no rodapé anterior. 


$$
=\left[\begin{array}{l}
\alpha_{A} \\
\alpha_{C h} \\
\alpha_{P_{y}} \\
\alpha_{R o t} \\
\alpha_{B r a s i l}
\end{array}\right]\left[\beta_{A} P_{A}+\beta_{C h} P_{C h}+\beta_{P y} P_{P y}+\beta_{R o t} P_{R o t}+\beta_{B r a s i l} P_{B r a s i l}\right]
$$

O procedimento de estimação de máxima verossimilhança do modelo de cointegração multivariável proposto por Johansen (1988) foi posteriormente ampliado em Johansen e Juselius $(1990,1992)$ para desenvolver testes de hipóteses sobre os parâmetros de longo prazo $(\alpha$ e $\beta)$.

Tomando a exposição resumida sobre o tema apresentada em Hansen e Juselius (1995, p.6-7) e Harris (1995, p.78-88), o procedimento de estimação de máxima verossimilhança é o seguinte. Em primeiro lugar, estima-se por modelo de correção de erro a regressão de $\Delta Z_{t}$ e $Z_{t-k}$ guardando os resíduos correspondentes em $R_{0 t}$ e $R_{k t}$ os quais são usados para formar a matriz dos resíduos.

$$
S_{i j}=T^{-1} \sum_{i=1}^{T} R_{i t} R_{j t}^{\prime} \quad i, j=0, \mathrm{k}
$$

A matriz $S_{\mathrm{ij}}$ é uma matriz $p \times{ }^{2}$. A matriz $\beta$ é estimada resolvendo a seguinte equação:

$$
\left|\lambda S_{k k}-S_{k 0} S_{00}^{-1} S_{0 k}\right|=0
$$

A solução para (15) acima é um conjunto de $p$ autovalores estimados, $\quad \hat{\lambda}_{1}>\hat{\lambda}_{2}>\ldots \hat{\lambda}_{p}$ Associados aos mesmos estão os correspondentes autovetores $\quad \hat{\boldsymbol{V}}=\hat{\boldsymbol{v}}_{1}, \ldots \hat{\nu}_{\text {p. }}$.

Aqueles $r$ elementos de $\mathbf{V}$ estimado que determinam relações de combinações estacionárias, são denotados por $\hat{\beta}=\left(\hat{v}_{1}, \ldots \hat{v}_{r}\right)$ os quais correspondem aos vetores de cointegração. A magnitude das estimativas de cada $\lambda_{i}$ é a medida de quão forte é a relação de cointegração $v_{i}^{\prime} Z_{t}(\mathrm{i}=1, \ldots \mathrm{r})$, também representada 
como $\beta_{i}^{\prime} Z_{t}$ e associada com a parte estacionária do modelo (Harris , p. 87). As últimas $(p-r)$ combinações são as combinações não estacionárias do modelo.

Johansen e Juselius (1990) apresentam duas estatísticas para testar a hipótese nula de que existem $\mathbf{r}$ vetores de cointegração. A primeira refere-se ao teste traço $\left(\lambda_{\text {traço }}\right)$ e a segunda ao teste de máximo autovalor $\left(\lambda_{\max }\right)$. Estes testes, contendo no máximo $\mathbf{r}$ vetores de cointegração, são aplicados seqüencialmente para valores decrescentes de $r$.

O teste traço ( $\left.\lambda_{\text {traço }}\right)$ é definido por:

$$
\lambda_{\text {trafo }}(r)=-T \sum_{i=r+1}^{p} 1 n\left(1-\hat{\lambda}_{i}\right) \quad \text { com } \mathrm{r}=0,1,2, \ldots, \mathrm{p}-1
$$

A hipótese de nulidade a ser testada é que existe pelo menos $r$ vetores de cointegração (e pelo menos n-r raízes unitárias), $H_{0}: \lambda_{\mathrm{i}}=0, \quad i=r+1, . . n$, onde os primeiros $r$ eigenvalues são diferentes de zero.

Em (16), $T$ é o número de observações disponíveis, r é o rank (posto) da matriz $\Pi$ (número de relações de cointegração); p é o número de variáveis do sistema e a estimativa de $\dot{\lambda}_{i}$ é o valor da i-ésima raiz característica da estimativa de $\Pi$.

Já o teste de máximo autovalor $\left(\lambda_{\max }\right)$ é associado à hipótese nula de que o número de relações de cointegração é igual a $\mathrm{r}\left[\mathrm{H}_{0}: \operatorname{rank}(\Pi)=r\right]$, enquanto a hipótese alternativa é o número de relações de cointegração ser igual a $(r+1)$.

$\mathrm{O}$ teste $\lambda_{\max }$ é definido pela expressão:

$$
\lambda_{\max }(r, r+1)=-T \ln \left(1-\lambda_{r+1}\right)
$$

Os valores críticos destes testes são encontrados em Johansen e Juselius (1990) e apresentados também em uma versão recalculada e estendida em OsterwaldLenum (1992). 


\subsubsection{Especificação dos modelos}

Antes de proceder aos testes de cointegração propriamente ditos deve-se definir o número de defasagens a ser utilizado para os vetores auto-regressivos do sistema. A eleição do número de defasagens "k" do modelo deve ser tal que torne o termo de erro não correlacionado temporalmente. Para tanto fez-se uso da versão multivariada dos Critérios de informação de Akaike(AIC) e Schwarz (SBC) aplicado sobre o modelo VAR em níveis. Tais estatísticas são expressas por:

$$
\begin{aligned}
& A I C=T \log |\Sigma|+2 N \\
& S B C=T \log |\Sigma|+N \log (T)
\end{aligned}
$$

Onde $|\Sigma|$ é o determinante da matriz de variância e covariância dos resíduos; $N$ é o número total de parâmetros a serem estimados em todas as equações, $T$ é o número de observações. Assim, se cada equação em um VAR com $p$ variáveis, $k$ defasagens e um intercepto, $N=p^{2} k+p$; cada das $p$ equações tem $k p$ regressores defasados e um intercepto (Enders, 1996, p. 117).

Outro aspecto a ser definido refere-se aos componentes determinísticos a serem incluídos no modelo, tanto na parte correspondente ao curto-prazo, expressa em diferenças (dummies estacionais, número de defasagens) como à correspondente ao longo-prazo, expressa em níveis (constante e tendência determinística).

Segundo Johansen e Juselius (1990, p. 170) a eleição do modelo a ser adotado requer uma especial e cuidadosa atenção dado que a distribuição assintótica das estatísticas dos testes de cointegração varia em função dos elementos determinísticos incluídos no modelo.

Assim um procedimento auxiliar para a escolha dos componentes determinísticos refere-se ao Critério de Pantula . Este procedimento foi sugerido por 
Johansen $(1992 b)^{61}$, segundo Harris (1995, p. 97) e permite testar conjuntamente o número de vetores de cointegração e os componentes determinísticos do modelo adequado para especificação.

Este procedimento testa a hipótese nula de não cointegração para um conjunto de modelos (em geral três modelos) os quais diferenciam entre si pelos componentes determinísticos que consideram nos dados ou nas relações de cointegração tais como tendência linear ou quadrática nos dados, e intercepto ou tendência no espaço de cointegração.

O procedimento estima para cada modelo o número de relações de cointegração $(r=0, r=1, \ldots r=p-1)$ e testa, a partir do modelo mais restrito (modelo com menor número de componentes determinísticos) até o menos restrito (modelo que apresenta termo constante e tendência temporal) a hipótese $r=0$ em cada modelo; à medida que a hipótese nula for rejeitada, segue-se testando $\mathrm{r}=1$, e assim sucessivamente . O teste é finalizado quando a hipótese nula de não cointegração não for rejeitada, escolhendo-se neste ponto o modelo a ser adotado.

\subsubsection{Testes sobre os elementos do vetor de cointegração $(\beta)$}

Após a determinação do número de vetores de cointegração existentes $\beta$, pode haver a necessidade de testar se estes vetores revelam algo sobre relações econômicas estruturais envolvidas no modelo de longo prazo, através da imposição de restrições sobre as colunas do vetor $\beta$.

Em geral estas restrições são formuladas limitando-se um ou alguns $\beta_{i j}$ a zero, ou como restrições de homogeneidade de forma que $\beta_{i j}=-\beta_{2 j}$.

As hipóteses a testar sobre os parâmetros $\beta$ encontra-se em (Johansen, $1990)^{62}$ e são representadas pela seguinte expressão geral:

\footnotetext{
${ }^{61}$ Johansen, S.; Juselius, K. Determination of cointegration rank in the presence of linear trend. Oxford Bulletin of Economics and Statistics, v. 54, p. 383-397, 1992.

${ }^{62}$ Em Johansen e Juselius $(1992,1994)$ estas hipóteses também são discutidas com apresentação de exemplos.
} 


$$
H_{\beta}: \beta=\left(H_{1} \varphi_{1}, H_{2} \varphi_{2}, \ldots, H_{r} \varphi_{r}\right)
$$

$H_{\beta}$ especifica (possíveis diferentes) restrições estruturais sobre cada vetor de cointegração, onde:

- $\mathbf{H}_{\mathbf{1}, \ldots . . .} \mathbf{H}_{\mathbf{r}}$ : são matrizes que expressam as hipóteses econômicas lineares a serem testadas sobre cada uma das $r$ relações de cointegração; têm dimensões $\left(\begin{array}{lll}p & \mathrm{x} & s_{i}\end{array}\right) \quad\left(r \leq s_{i} \leq p\right)$ sendo $s_{i}$ o número de coeficientes de $\beta$ que não estão restritos. $H_{i}$ impõe $k i$ restrições de forma que $k i+s_{i}=p$. Johansen e Juselius (1990. p. 172) definem a matriz $H^{*}$ como $H$, a distinção entre uma e outra é que $H^{*} \cdot$ a matriz de restrição para o modelo de cointegração que contém um termo constante ( no qual tendência não esteja presente).

- $\varphi$ : é uma matriz $s \times r$, sendo $p$ - $s$ o número de restrições impostas em $\mathbf{H}$, cada $\varphi_{i}$ é um vetor $\left(s_{i} \times 1\right)$ de parâmetros a serem estimados na itésima relação de cointegração.

A estatística para testar esta hipótese também pertence à família de testes de máxima verossimilhança e é representada pela seguinte equação:

$$
\left|\lambda H^{\prime} S_{I 1} H-H^{\prime} S_{10} S^{-1}{ }_{11} S_{01} H \quad\right|=0
$$

O entendimento das hipóteses quanto às restrições aos parâmetros $\beta$ é facilitado quando se consideram 3 casos especiais sugeridos por Johansen e Juselius (1992) e representativos do teste de hipótese geral (20). Abaixo estão relacionados 2 destes três casos especiais que serão utilizados para conduzir as análises empíricas neste trabalho:

1. As mesmas $(p-s)$ restrições sobre os parâmetros $\beta$ são impostas sobre todos os vetores de cointegração. Esta hipótese é especificada como :

$$
H_{1}: \beta=H \varphi
$$


Como $\mathrm{H}$ impõe $k$ restrições, terá dimensões $(p \times s)$, uma vez que $(\mathrm{s}=\mathrm{p}-\mathrm{k})$; matriz $\varphi$ é uma matriz $(s \times \mathrm{x} r$ ) de parâmetros a serem estimados envolvendo $\mathrm{r}$ vetores de cointegração. Esta hipótese é usada para ver se uma estrutura particular é assegurada em todas as relações de cointegração;

2. Quando se deseja testar se $r_{l}$ vetores de cointegração conhecidos e os remanescentes $r_{2}$ vetores são não restritos $\left(r_{1}+r_{2}=r\right)$. Esta restrição é representada da forma:

$$
H_{3}: \beta=\left(H_{1} \varphi_{1}, H_{2} \varphi_{2}\right)
$$

Onde $\mathbf{H}_{1}$ e $\mathbf{H}_{2}$ agora representam dois grupos de hipóteses, o primeiro grupo compreende $r_{l}=I$ vetor de cointegração supostamente conhecido e o segundo vetor compreende $r_{2}\left(=r-r_{l}\right)$ vetores não restritos. Há $(p-l)$ restrições impostas ao vetor

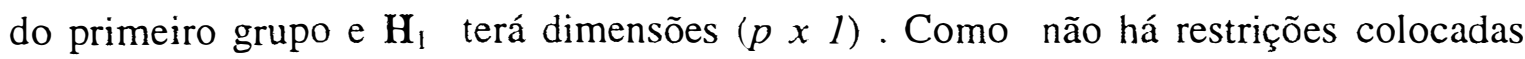
sobre $\mathbf{H}_{2}$, esta torna-se matriz identidade com dimensão $(p x p) ; \varphi_{1}$ é uma matriz $\left(s_{1}\right.$ $\left.\begin{array}{ll}x & r_{l}\end{array}\right)$ de parâmetros a serem estimados envolvendo o vetor de cointegração supostamente conhecido e $\varphi_{2}$ é uma matriz $\left(n \times r_{2}\right)$ de parâmetros envolvendo $r_{2}$ vetores de cointegração. ${ }^{63}$

Operacionalmente, as hipóteses sobre $\beta$ são formuladas adotando, para cada caso concreto a forma e dimensão da matriz $\mathbf{H}$ apropriada; a definição dos testes efetuados e a definição das matrizes vinculadas encontram-se no capítulo referente aos resultados.

\footnotetext{
${ }^{63}$ Exemplos da formulação destas hipóteses H podem ser encontrados em Hansen e Juselius (1995), Harris (1995), além de Johansen e Juselius $(1990,1992)$.
} 


\subsubsection{Testes de hipóteses sobre os parâmetros alfa (testes de exogeneidade fraca)}

A formulação especificada em (13) é usada como base para testar exogeneidade fraca entre as variáveis do sistema. Partindo de uma especificação multivariada para investigar a LPU, o teste de exogeneidade fraca pode ser útil para investigar, dentre as variáveis de preços internacionais de uma commodity, quais podem ser consideradas exógenas em relação, por exemplo, ao padrão de equilíbrio determinado pela(s) relação(ções) de cointegração obtida(s).

Para que uma variável seja considerada exógena fraca, com relação a um determinado vetor de cointegração, o coeficiente $\alpha_{i j}$, associado à variável, não deve diferir estatisticamente de zero. Ou seja, o teste de exogeneidade fraca é feito impondo restrições zero aos coeficientes da matriz $\alpha$, que fornece uma medida da velocidade média de convergência para o equilíbrio de longo prazo (Hansen \& Juselius, 1995, p.3).

A hipótese nula a ser testada é que $\mathrm{p}$ coeficientes de $\alpha_{i j}$ não diferem significativamente de zero $\left[H_{0}: \alpha_{\mathrm{ij}}=0\right.$ para $\left.\mathrm{j}=1, \ldots \mathrm{r}\right]$, com $i$ identificando a variável (supostamente exógena) e o $j$ vetor de cointegração em análise. As hipóteses sobre as restrições de $\alpha$ podem ser representadas de duas formas:

$$
\alpha=A \phi \quad \text { ou } \quad\left(B^{\prime} \alpha=0\right)
$$

onde A é uma matriz $\left(\begin{array}{lll}p & x & m\end{array}\right)$ e $m$ é o número de coeficientes $\alpha$ não restritos. Esta mesma hipótese pode ser expressa da forma exposta entre parênteses por especificar uma matriz $\mathbf{B}$ de dimensões $[p \times(p-m)]$ tal que $\mathbf{B}^{\prime} \mathbf{A}=0$ e $(p-m)$ é igual ao número de linhas de restrições impostas sobre $\alpha$.

A função de verossimilhança para o teste desta hipótese adota a seguinte expressão:

$$
-2 \ln (Q)=T \sum \ln \left[\left(1-\lambda_{1 i}\right) /\left(1-\lambda_{i}\right)\right] \quad \mathrm{i}=1,2, \ldots, \mathrm{r}
$$


Onde $Q=$ (máxima verossimilhança restrita $\div$ máxima vierossimilhança não restrita). Esta estatística é comparada à distribuição $\chi^{2}$ de $r \times(p-m)$ graus de liberdade para obter o nível de significância para rejeição da hipótese nula.

Em resumo tem-se que as restrições sobre $\alpha$ são formuladas definindose, para cada caso concreto as formas e dimensões das matrizes B (em 24). A definição dos testes efetuados, assim como as matrizes vinculadas encontram-se discutidos no capítulo de resultados.

\subsection{Definição dos dados utilizados}

A eleição das séries de dados utilizadas objetivou considerar alguns dos maiores mercados exportadores de cada um dos produtos, incluindo países do Mercosul, reconhecidos por terem participação significativa nas importações brasileiras. e o Brasil, entendendo este país como importador líquido daquelas commodities no período em apreço. Desta forma, a análise reportará as relações entre os seguintes mercados:

- para o caso do milho: Argentina, Brasil, Paraguai, Estados Unidos (Chicago - preço futuro primeira entrega) e Estados Unidos (CIF Roterdã ), período janeiro de 1990 a junho de 1998:

- para o caso do arroz: Tailândia (Bangkok), Brasil, Uruguai e Argentina, período janeiro del990 a junho de 1998, e

- para o caso do algodão: mercado de Liverpool Índices A e B, Estados Unidos (Nova Iorque - futuro primeira entrega), Argentina, Brasil e Paraguai. Neste caso, para tornar possível trabalhar com todas estas séries de preços foi necessário segmentar a análise em dois modelos, em função da inexistência de séries organizadas de preços na Argentina e Paraguai para anos anteriores a 1994. Desta forma, um segundo modelo foi organizado para possibilitar a inclusão das séries destes países. Portanto a análise no caso do algodão contemplará os modelos: 
Modelo I: Séries Liverpool Índice B, Liverpool Índice A, Estados Unidos (Nova Iorque), Brasil/Santos, período janeiro de 1990 a junho de1998, e Modelo II:_Séries Liverpool Índice B, Liverpool Índice A, Estados Unidos (Nova Iorque), Brasil/Santos, Argentina e Paraguai, período janeiro de 1994 a dezembro de 1997.

Desde 1972 a publicação Cotton Outlook de Liverpool apresenta estatísticas diárias de preços de algodão de várias origens do mundo cotados CIF em portos do Norte da Europa. Com tais informações são elaboradas as médias denominadas Índice "A" e Índice "B". O Índice "A" é uma média das 5 origens mais baratas tomadas de ụm seleção de 14 origens consideradas como de maior qualidade, e o Índice "B" é uma média das 3 origens mais baratas tomadas de uma seleção de 8 origens consideradas como de menor qualidade. Em função disto é comum adotar-se os valores correspondentes aos índices "A" e "B" como referência de preços mundiais. O algodão brasileiro tipo $5 / 6$ de 1- 1/16" (equivalente a $32 \mathrm{~mm}$ ) e o algodão argentino correspondente ao grau C-1/2 de 1-1/16" potencialmente podem participar da formação do Índice "B" enquanto o algodão Paraguaio, ainda que similar ao algodão argentino, quando se enquadra entre as origens mais baratas, participa da formação do Índice "A" pela maior oferta de exportaçāo e continuidade no mercado internacional. ${ }^{64}$ No horizonte temporal compreendido por este estudo, o produto brasileiro não participou da composição do Índice B, uma vez que foram mínimas as exportações brasileiras no período.

Nesta década, embora o Brasil praticamente não tenha apresentado excedentes exportáveis de algodão, a Companhia Nacional de Abastecimento (CONAB) elabora sistematicamente a composição dos preços de exportação posto em Santos, utilizados como referência dos preços FOB de algodão brasileiro.

As características e fontes dos dados encontram-se sumarizadas no quadro 12 (página 94). Para Goodwin, et al. (1990) os preços de fronteira são mais apropriados para testar a LPU do que preços internos porque eles representam melhor oportunidades

${ }^{64}$ Estas informações são do Anuário de Estatísticas de precios e cotizaciones de algodón (1995). Secretaría de Agricultura, Pesca y Alimentacíon (SAGYPA), Argentina. 
de arbitragem. Por outro lado, Isard (1977) afirma que, testes para LPU para produtos vendidos competitivamente podem também ser realizados indiferentemente a partir de preços internacionais no atacado, preços de exportação ou um misto de ambos, tal procedimento foi também utilizado por Ardeni (1990). Neste trabalho, nos casos em que não foi possível a obtenção dos preços de fronteira adequados recorreu-se a este expediente. Assim, preços a nível de mercado atacadista foram utilizados para o milho origem Paraguai e arroz origem Brasil.

Dentre as séries de preços utilizadas duas são de mercados futuros (primeira entrega): Algodão origem Estados Unidos/Nova Iorque e milho origem Estados Unidos/ Chicago. Granger, conforme Karbuz e Jumah (1995) menciona que, como os preços à vista e futuro de uma mesma commodity tendem a ter comportamentos semelhantes no longo prazo, não há restrições para a utilização de preços no mercado disponível e futuro em testes bivariados ou multivariados para análise de integração de mercados.

Em estudos de integração de mercados deve-se idealmente trabalhar com séries de preços associadas a produtos homogêneos e expressos em moeda comum. Quanto ao primeiro requisito, neste trabalho não foi possível selecionar, para todos os produtos de cada modelo, dados de uma mesma fonte, entretanto, procurou-se selecionar as séries de produtos comparáveis. Quanto ao segundo requisito todas as séries de preços foram expressas em real utilizando para sua conversão a taxa de câmbio nominal real/dólar.

Neste estudo não se visualizou a possibilidade de utilizar a paridade de poder de compra (PPC) na conversão dos preços para uma mesma moeda por entender que a arbitragem de preços decorre da comparação de preços nominais quando estes se expressam em uma moeda cuja paridade é definida no mercado. Assim, entende-se que os operadores dos mercados de commodities agrícolas avaliam em um determinado momento se, ao tipo de câmbio vigente, o diferencial de preços entre países permite a obtenção de lucros mediante o transporte das mercadorias do país com preços menores para o país com maior preço. 
A PPC é muito utilizada quando se está interessado em comparar magnitudes de valores agregados em distintos países. O uso da PPC permite eliminar os efeitos dos distintos níveis de preços vigentes em diferentes países, ao igualar o poder de compra de suas respectivas moedas. Se o índice de preços calculado a partir de uma cesta de bens comum (a todos os países), utilizada no cômputo da PPC não for representativa do bem objeto de estudo, então o uso da PPC estaria distorcendo as séries de preços individuais e dificultando a interpretação dos resultados.

Custos de frete são considerados componentes importantes nas ligações de preços de commodities comercializadas internacionalmente. Em uma situação de perfeita arbitragem, preços de commodities em mercados importadores e exportadores não deveriam diferir mais do que os custos de transporte entre os dois mercados. Entretanto, séries históricas oficiais ou independentes sobre custos de transporte são muito raramente disponíveis. Apesar de várias tentativas, não foi possível obter junto a tradings (importadores e exportadores) séries históricas para todo o período da análise, mas para milho e arroz foi possível realizar uma média aritmética simples dos custos de frete (ou transbordo) de valores vigentes nos últimos anos e incorporá-los à análise, os quais encontram-se nos quadros A.1 e A.2 do apêndice.

No caso do arroz foi possível obter junto ao Instituto Riograndense do Arroz (IRGA), o custo médio de frete das duas últimas safras para o produto proveniente do Uruguai, Argentina e Paraguai. No caso do frete de milho as taxas médias para o período 1994/98 foram obtidas junto à empresa Refinações de Milho Brasil e no caso do algodão utilizou-se o custo médio histórico de frete ${ }^{65}$ (US\$ 5,37 cents/libra-peso). Assim, os dados utilizados de preços internacionais FOB e CIF foram corrigidos para tornarem-se preços CIF Brasil. Na composição destes foram considerados também as alíquotas de impostos de importação e seguro internacional.

\footnotetext{
${ }^{65}$ Segundo informações pessoais fornecidas por Sr. Richard O'Conell da empresa Santista o custo do frete para importação de algodão não sofreu oscilações significativas nesta década.
} 
As alíquotas dos impostos de importação para algodão e arroz são as apresentadas nos quadros 3 e 6 (páginas 48 e 57, respectivamente). No caso do milho utilizou-se as mesmas tarifas indicadas para o arroz.

Quadro 12 - Características e fontes dos dados utilizados.

\begin{tabular}{|c|c|c|}
\hline Commodity & Descrição/ Fonte dos dados & $\begin{array}{l}\text { Período } \\
\text { (ano/mês) }\end{array}$ \\
\hline Milho Brasil & FOB Paraná em grãos (CONAB) & $90 / 1-98 / 6$ \\
\hline Milho Paraguai & $\begin{array}{l}\text { Atacado Assunção, (Ministério da Agricultura } \\
\text { e Ganaderia do Paraguai) }\end{array}$ & $90 / 1-98 / 6$ \\
\hline Milho Argentina & FOB Buenos Aires - $(\text { INDEC })^{66}$ & $90 / 1-98 / 6$ \\
\hline Milho USA & Chicago - Preço Futuro $1^{\underline{a}}$ entrega (CONAB) & $90 / 1-98 / 6$ \\
\hline Milho USA & CIF Roterdã, n.3, Yelllow (USDA) & $90 / 1-98 / 6$ \\
\hline Algodāo Argentina & $\begin{array}{l}\text { FOB Buenos Aires, não cardado nem } \\
\text { penteado (INDEC) }\end{array}$ & $94 / 1-97 / 12$ \\
\hline Algodão Paraguai & $\begin{array}{l}\text { FOB Assumpção, não cardado } \\
\text { penteado }^{67} \text { (BANCO } \\
\text { PARAGUAI) }\end{array}$ & $94 / 1-97 / 12$ \\
\hline Algodão Brasil & FOB Santos (CONAB) & $90 / 1-98 / 6$ \\
\hline Algodão Liverpool & Pluma Índice B (CONAB) & $90 / 1-98 / 6$ \\
\hline Algodão Liverpool & Pluma Índice A (CONAB) & $90 / 1-98 / 6$ \\
\hline Algodão Nova Iorque & Pluma Futuro $1^{\underline{a}}$ Entrega (CONAB) & $90 / 1-98 / 6$ \\
\hline Arroz Brasil & Atacado/Paraná (CONAB) & $90 / 1-98 / 6$ \\
\hline Arroz Argentina & FOB Buenos Aires (SAGYPA) ${ }^{68}$ & $90 / 1-98 / 6$ \\
\hline Arroz Uruguai & $\begin{array}{l}\text { FOB Montevidéu (Câmara Setorial/ } \\
\text { Ministério de Ganaderia, Agricultura y Pesca) }\end{array}$ & $90 / 1-98 / 6$ \\
\hline Arroz Tailândia & Disponível Bangkok (CONAB) & $90 / 1-98 / 6$ \\
\hline
\end{tabular}

${ }^{66}$ Instituto Nacional de Estatísticas e Censos da Argentina.

${ }^{67}$ Algodão não cardado diz respeito à fibra não destrinçada, não desinredada.

${ }^{68}$ Secretaria de Agricultura Pesca e Alimentação/ Ministério de Economia, Obras e Serviços Públicos, Argentina. 


\section{RESULTADOS E DISCUSSÃO}

Neste capítulo são apresentados e discutidos os resultados obtidos nos testes de raiz unitária (6.1), na estimação do vetor de cointegração (6.2), assim como os testes de hipóteses sobre os parâmetros $\beta$ e $\alpha$ ( 6.3)

\subsection{Testes de raiz unitária}

Previamente à análise de cointegração, foram realizados, como é usual, testes para verificar se cada série, dentre aquelas que a princípio deverão participar das análises de cointegração nos mercados das três commodities em apreço, é integrada ${ }^{69} \mathrm{e}$, ademais, que todas o são de mesma ordem.

Baffes (1991) assinala que se as variáveis são integradas de ordens distintas, a LPU não se satisfaz ou que os mercados não estão integrados porque ao menos uma das variáveis pode ter um comportamento explosivo que não pode ser explicado pelos outros preços, invalidando a possibilidade de equilíbrio entre eles.

Como indicado no capítulo anterior, para estudar a ordem de integrabilidade das séries, foram realizados testes de raiz unitária, com base nos testes de Dickey Fuller Aumentado (DFA), os quais, para as séries abordadas neste trabalho, encontram-se nas tabelas 1 a 4 .

Nestas, os modelos designados como (I), (II) e (III) reportam-se aos testes com as séries tomadas em primeiras diferenças. As particularidades associadas a cada um destes modelos estão discutidas no capítulo anterior (ítem 5.1.2) e apresentadas em (7) e quadro 11 , do mesmo capítulo. Os modelos apresentados nas duas últimas

\footnotetext{
${ }^{69}$ Lembrando que, se uma série deve ser diferenciada uma vez para tornar-se estacionária $\mathrm{I}(0)$, então dizse que esta série é integrada de ordem um, I(1).
} 
linhas daquelas tabelas como (II) e/ou (III) (séries nas $\Delta \Delta \mathrm{Y}_{\mathrm{t}}$ ), reportam-se aos correspondentes modelos (II) e (III) com as séries tomadas em segundas diferenças.

\subsubsection{Testes de raiz unitária para séries de algodão}

Nas tabelas 1 e 2 encontram-se os resultados dos testes de raiz unitária respectivamente para os dois modelos das séries de algodão envolvendo os períodos 1994/1997 e 1990/98.

Para a série Liverpool Índice A do modelo para algodão (1994/97) o resultado estatística $\tau_{\tau}$ (modelo I) permite rejeitar a hipótese nula de não estacionariedade, a favor da hipótese alternativa de que trata-se de uma série estacionária. O resultado da estatística $\phi_{3}$ para esta série, embora não ofereça rejeição para a hipótese conjunta de existência de raiz unitária sem tendência e com possível termo de intercepto, tem um valor próximo ao valor crítico (5\% de significância). Tendo em vista estes resultados, pode-se assumir que esta série caracteriza-se por ser estacionária e será excluída das relações de cointegração nas análises que se seguem.

A estatística $\tau_{\beta \tau}$ (modelo I) provê a verificação especificamente para a existência de tendência; os resultados desta estatística para todas as séries não permitem rejeitar a hipótese nula, indicando que as mesmas não apresentam tendência determinística.

A estatística $\phi_{2}$, associada ao modelo I, proporciona a verificação para a hipótese de existência de um termo de intercepto $(\alpha=0)$ no processo que explica a geração dos dados, dada a informação a priori (por $\tau_{\tau}$ e $\phi_{3}$ ) de que a série possivelmente apresente raiz unitária. Havendo rejeição da hipótese nula, a série possivelmente é um caminho aleatório com drift (intercepto), o que é verificado para as séries Liverpool Índices B, Nova Iorque e Argentina. Se não for possível rejeitar a hipótese nula a série é um caminho aleatório sem drift; como é o caso das séries Brasil e Paraguai. A série Liverpool Índice A, sendo estacionária, o é em torno de uma constante e não em torno de uma tendência determinística. 
Tabela 1 - Testes de raiz unitária (Dickey-Fuller Aumentado) para as séries de algodão, 1994/01-1997/12.

\begin{tabular}{|c|c|c|c|c|c|c|c|c|c|}
\hline \multirow[t]{2}{*}{ MODELO } & \multirow[t]{2}{*}{$\begin{array}{l}\text { ESTATIS- } \\
\text { TICA }\end{array}$} & \multicolumn{2}{|c|}{$\begin{array}{l}\text { VALORES } \\
\text { CRÍTICOS }\end{array}$} & \multirow{2}{*}{$\begin{array}{c}\text { Índice } \\
\mathbf{A}^{1 /} \\
(1)\end{array}$} & \multirow{2}{*}{$\begin{array}{c}\text { Índice } \\
\mathbf{B}^{1 / /} \\
(1)\end{array}$} & \multirow[t]{2}{*}{$\begin{array}{c}\text { N.Iorque } \\
\text { (1) }\end{array}$} & \multirow{2}{*}{$\begin{array}{c}\text { Brasil }^{\text {I/ }} \\
\text { (1) }\end{array}$} & \multirow{2}{*}{$\begin{array}{l}\text { Argen- } \\
\text { tina }{ }^{1 /} \\
\quad(2)\end{array}$} & \multirow{2}{*}{$\begin{array}{c}\text { Para- } \\
\text { Guai }^{1 /} \\
\text { (2) }\end{array}$} \\
\hline & & $(5 \%)$ & $(1 \%)$ & & & & & & \\
\hline \multirow[t]{4}{*}{ (I) } & $\tau_{\tau}$ & $-3,45$ & $-4,04$ & $-4,18 * *$ & $-3,07$ & $-3,13$ & $-2,13$ & $-3,12$ & $-2,21$ \\
\hline & $\phi_{3}$ & 6,49 & 8,73 & 6,35 & 3,57 & 3,55 & 1,71 & 3,26 & 1,75 \\
\hline & $\tau_{\beta \tau}$ & 2,79 & 3,53 & $-2,78$ & $-2,02$ & $-2,46$ & $-1,36$ & $-2,19$ & $-1,42$ \\
\hline & $\phi_{2}$ & 4,88 & 6,50 & $9,02 *$ & $4,96^{*}$ & $4,92 *$ & 2,57 & $4,89 *$ & 2,52 \\
\hline \multirow[t]{3}{*}{ (II) } & $\tau_{\mu}$ & $-2,59$ & $-3,51$ & - & $-2,33$ & $-1,82$ & $-1,79$ & $-2,13$ & 0,62 \\
\hline & $\tau_{\alpha \mu}$ & 2,54 & 3,22 & - & 2,28 & 1,78 & 1,79 & 2,12 & 0,63 \\
\hline & $\phi_{1}$ & 4,71 & 6,70 & - & 3,33 & 2,03 & 1,61 & 2,28 & 0,22 \\
\hline (III) & $\tau$ & $-1,95$ & $-2,60$ & - & $-1,15$ & $-0,90$ & $-0,06$ & $-0,20$ & $-0,49$ \\
\hline $\begin{array}{l}\text { (II) série } \\
\text { nas } \Delta \Delta \mathrm{Y}_{\mathrm{t}}\end{array}$ & $\tau_{\mu}$ & $-2,59$ & $-3,51$ & - & $3,61^{*}$ & $4,81^{*}$ & - & $-5,57^{*}$ & - \\
\hline $\begin{array}{l}\text { (III) série } \\
\text { nas } \Delta \Delta \mathrm{Y}_{\text {, }}\end{array}$ & $\tau$ & $-1,95$ & $-2,60$ & - & $3,57^{*}$ & $4,75^{*}$ & $3,52 *$ & $-5,65^{*}$ & $-4,32^{*}$ \\
\hline
\end{tabular}

"O valor entre parênteses indica o número de defasagens utilizado na regressão.

* indica que se rejeita a hipótese nula a $5 \%, * *$ indicam rejeição a $1 \%$.

Os valores críticos encontram-se em Dickey e Fuller (1981, p. 1062-1063).

Fonte: dados da pesquisa.

As estatísticas $\tau_{\alpha \mu}$ e $\phi_{1}$, associadas ao modelo II, impõem restrição de tendência zero e representam tentativas de restabelecer as conclusões sobre o termo de intercepto, segundo Holden e Perman (1994). Enquanto a estatística $\tau_{\alpha \mu}$ impõe restrição de nulidade para o termo de intercepto $(\alpha), \phi_{1}$ impõe a mesma restrição, porém para a hipótese conjunta de existência de raiz unitária e termo de intercepto nulo, $\left[\mathrm{H}_{0:}(\alpha, \rho)=\right.$ $(0,1)$ contra $\left.\mathrm{H}_{0:}(\alpha, \rho) \neq(0,1)\right]$ em (9) página 76 do capítulo anterior.

Os resultados das estatísticas $\tau_{\alpha \mu}$ e $\phi_{1}$ no caso das séries Índice B, Nova Iorque e Argentina não são idênticos aos apontados por $\phi_{2}$ e, para as três séries, não permitem rejeitar as respectivas hipóteses nulas, indicando que os processos geradores destas séries possivelmente possam ser caracterizados como sendo caminhos aleatórios sem constante e sem tendência. Portanto, dadas as indicações não semelhantes dos resultados para as estatísticas $\phi_{2}$ por um lado e $\tau_{\alpha \mu}$ e $\phi_{1}$ por outro, a verificação de 
que aquelas três séries são integradas de ordem um pode ser visualizada a partir da apresentação dos resultados em segundas diferenças, tanto referentes ao modelo (II) quanto ao modelo (III), os quais permitem rejeitar a hipótese de nulidade de que as séries não são integradas de ordem um, I(1).

Avaliando-se agora os resultados da estatística $\tau$ (modelo III) para as séries Brasil e Paraguai. dada a informação $a$ priori oferecida tanto por $\phi_{2}$ quanto por $\tau_{\alpha \mu}$ e $\phi_{1}$ de que estas não contêm termo de intercepto, tem-se que os resultados da estatística $\tau$ também conduzem a concluir que estas séries são não estacionárias $\mathrm{e}$ integradas de ordem um.

Em resumo, para as séries de algodão no modelo para o período 1994/97, com exceção da série Liverpool Índice A, os resultados não permitem rejeitar que todas as demais são não estacionárias e integradas de ordem um, portanto, apresentam uma raiz unitária . podendo ser utilizadas nas análises de cointegração que se seguem.

Para as séries de preços de algodão envolvendo o período 1990 - 1998, os testes de raiz unitária estão apresentados na tabela 2.

Segundo os resultados da estatística $\tau_{\tau}$ não se pode rejeitar a hipótese de que as séries Índice A e Nova Iorque sejam estacionárias, de forma que serão excluídas das relações de cointegração (embora a estatística $\phi_{3}$ não permita rejeitar, para a série Índice $\mathrm{A}$, a hipótese conjunta de existência de raiz unitária sem tendência e com possível intercepto).

No caso das séries Índice B e Brasil as indicações são de que tratam-se de séries não estacionárias e integradas de ordem um, sendo o processo gerador dos dados em ambas as séries associado a um modelo sem constante e sem tendência (modelo III), uma vez que os resultados não permitiram rejeitar as respectivas hipóteses nulas para as estatísticas $\phi_{3,} \tau_{\beta \tau}, \phi_{2}, \tau_{\mu}$ e $\tau_{\alpha \mu}$. 
Tabela 2 - Testes de raiz unitária (Dickey-Fuller Aumentado) para as as séries de algodão, 1990/01 - 1998/06.

\begin{tabular}{|c|c|c|c|c|c|c|c|}
\hline \multirow[t]{2}{*}{ MODELO } & \multirow[t]{2}{*}{$\begin{array}{l}\text { ESTATÍS- } \\
\text { TICA }\end{array}$} & \multicolumn{2}{|c|}{$\begin{array}{l}\text { VALORES } \\
\text { CRÍTICOS }\end{array}$} & \multirow{2}{*}{$\begin{array}{c}\text { Índice }^{\mathbf{A}^{\mathrm{I}}} \\
(4)\end{array}$} & \multirow{2}{*}{$\begin{array}{c}\text { Índice B }^{\text {II }} \\
\text { (9) }\end{array}$} & \multirow{2}{*}{$\begin{array}{c}\text { N.Iorque }^{\text {II }} \\
\text { (2) }\end{array}$} & \multirow{2}{*}{$\begin{array}{c}\text { Brasil }^{1} \\
\text { Santos } \\
(2)\end{array}$} \\
\hline & & $(5 \%)$ & $(1 \%)$ & & & & \\
\hline \multirow[t]{4}{*}{ I } & $\tau_{\tau}$ & $-3,45$ & $-4,04$ & $-4,08^{*}$ & $-2,63$ & $-4,41^{* *}$ & $-2,45$ \\
\hline & $\phi_{3}$ & 6,49 & 8,73 & 5,85 & 2,98 & $6,49^{*}$ & 2,01 \\
\hline & $\tau_{\beta \tau}$ & 2,79 & 3,53 & $-3,73^{* *}$ & $-2,75$ & $-3,58^{* *}$ & 0,43 \\
\hline & $\phi_{2}$ & 4,88 & 6,50 & $8,39^{* *}$ & 3,88 & $9,74^{*}$ & 3,01 \\
\hline \multirow[t]{3}{*}{ II } & $\tau_{\mu}$ & -2.59 & $-3,51$ & - & $-0,41$ & - & $-2,42$ \\
\hline & $\tau_{\alpha \mu}$ & 2.54 & 3,22 & - & 0,36 & - & 2,43 \\
\hline & $\phi_{1}$ & 4,71 & 6,70 & - & 0,63 & - & 2,96 \\
\hline III & $\tau$ & $-1,95$ & -2.60 & - & $-1,07$ & - & $-2,12$ \\
\hline $\begin{array}{l}\text { III série } \\
\text { nas } \Delta \Delta Y_{t}\end{array}$ & $\tau$ & -3.45 & $-4,04$ & - & $-5,52^{*}$ & - & $-8,07^{*}$ \\
\hline
\end{tabular}

"O valor entre parênteses indica o número de defasagens utilizado na regressão.

* indica que se rejeita a hipótese nula a $5 \%,{ }^{* *}$ indicam rejeição a $1 \%$.

Os valores críticos encontram-se em Dickey e Fuller (1981, p. 1062-1063).

Fonte: dados da pesquisa.

\subsubsection{Testes de raiz unitária para séries de milho}

Na tabela 3 estão apresentados os resultados dos testes DFA para as séries de milho no período 1990/98. A série Paraguai mostra-se claramente estacionária, segundo as indicações das estatísticas $\tau_{\tau}$ e $\phi_{3}$. Observando-se a evolução do conjunta das séries de preços de milho indicada na figura 13 (pagina 71), pode-se verificar que os preços do Paraguai destoam significativamente do padrão de evolução dos demais preços no período 1990-94, o que pode ser a razão da possível estacionariedade desta série, ao contrário das demais. Sendo estacionária, esta série o é em torno de uma tendência e uma constante tomando-se em consideração as indicações das estatísticas $\phi_{2}, \phi_{3}$ e $\tau_{\beta \tau}$. 
Tabela 3 - Resultados dos testes de raiz unitária para as séries de milho, $1990 / 01$ - 1998/06.

\begin{tabular}{l|c|c|c|c|c|c|c|c}
\hline MODELO & \multirow{2}{*}{\begin{tabular}{l} 
TSTATIS- \\
\cline { 3 - 8 }
\end{tabular}} & \multicolumn{2}{|c|}{$\begin{array}{c}\text { VALORES } \\
\text { CRÍTICOS }\end{array}$} & $\begin{array}{c}\text { Argentina } \\
(1)\end{array}$ & $\begin{array}{c}\text { Chicago } \\
(4)\end{array}$ & $\begin{array}{c}\text { Roterda }^{1} \\
(1)\end{array}$ & $\begin{array}{c}\text { Paraguai }^{1} \\
(2)\end{array}$ & $\begin{array}{c}\text { Brasil }^{1} \\
(7)\end{array}$ \\
\cline { 2 - 9 } & $(5 \%)$ & $(1 \%)$ & & & & & \\
\hline I & $\tau_{\tau}$ & $-3,45$ & $-4,04$ & $-3,44$ & $-2,75$ & $-2,96$ & $5,00^{*}$ & $-3,38$ \\
& $\phi_{3}$ & 6,49 & 8,73 & 4,17 & 2,61 & 3,15 & $8,97^{* *}$ & 4,13 \\
& $\tau_{\beta \tau}$ & 2,79 & 3,53 & $-2,89^{*}$ & $-1,72$ & $-2,58$ & $4,49^{* *}$ & $-3,13^{*}$ \\
& $\phi_{2}$ & 4,88 & 6,50 & $6,20^{*}$ & 3,79 & 4,64 & $13,44^{* *}$ & $5,73^{*}$ \\
\hline II & $\tau_{\mu}$ & $-2,59$ & $-3,51$ & $-1,93$ & $-2,11$ & $-1,57$ & - & $-1,22$ \\
& $\tau_{\alpha \mu}$ & 2,54 & 3,22 & $5,15^{* *}$ & 2,06 & 1,54 & - & 1,13 \\
& $\phi_{1}$ & 4,71 & 6,70 & 1,91 & 2,38 & 1,32 & - & 1,17 \\
\hline III & $\tau$ & $-1,95$ & $-2,60$ & 1,55 & 0,68 & $-0,52$ & - & $-1,02$ \\
\hline II nas $\Delta \Delta \mathbf{Y}_{\mathbf{t}}$ & $\tau_{\mu}$ & $-2,59$ & $-3,51$ & $-7,16^{* *}$ & - & - & - & $-4,69^{* *}$ \\
\hline
\end{tabular}

${ }^{1 / O}$ valor entre parênteses indica o número de defasagens utilizado na regressão.

* indica que se rejeita a hipótese nula a 5\%, ** indicam rejeição a $1 \%$.

Os valores críticos encontram-se em Dickey e Fuller (1981, p. 1062-1063).

Fonte: dados da pesquisa.

No caso das séries Argentina e Brasil os resultados da estatística $\tau_{\beta \tau}$ em ambos os casos permitiram rejeitar a hipótese de nulidade para o termo de tendência, sugerindo que o modelo mais adequado para explicar o comportamento das mesmas seja o modelo I. Entretanto, verifica-se também que os resultados da estatística $\phi_{3}$ não permitiram rejeitar a hipótese de que estas séries possam ser explicadas por um modelo contendo apenas um termo de intercepto, sem tendência. A mesma interpretação pode ser dada para a rejeição das estatísticas $\phi_{2}$ nas duas séries, embora $\phi_{1}$ não permita rejeitar a hipótese de nulidade para o termo constante. No contexto, tomando-se por referência as indicações de $\phi_{3}$ e $\phi_{2}$, adota-se o modelo II como referência para explicar o comportamento daquelas séries. Portanto, os resultados das estatística $\tau_{\mu}$ e $\tau_{\mu}$ no modelo em segundas diferenças indicam que as mesmas são integradas de ordem um.

Já as séries Chicago e Roterdã, embora os resultados da estatística $\phi_{3}$ não permitam rejeitar a hipótese conjunta de raiz unitária sem tendência com possível 
intercepto, os resultados das estatísticas $\phi_{2}$ e $\tau_{\alpha \mu}$ para existência de termo de intercepto apontam não rejeição das hipóteses de nulidade sugerindo que possivelmente estas não contêm um termo de intercepto. Dessa forma, estas são integradas de ordem um, sendo o modelo III (sem constante e sem tendência) o mais adequado para explicar o comportamento das mesmas. A rejeição da hipótese de nulidade da estatística $\tau$ no modelo em segundas diferenças indica que aquelas séries são integradas de ordem um.

\subsubsection{Testes de raiz unitária para séries de arroz}

Neste caso, analisando os resultados das estatísticas $\tau_{\tau}$ (a $1 \%$ de significância) e $\phi_{3}$ pode-se concluir que todas as séries de arroz abordadas neste estudo são não estacionárias, uma vez que não foi possível rejeitar, em todos os casos, a hipótese de existência de raiz unitária com possível intercepto (tabela 4). Embora a estatística $\tau_{\tau}$ indique, a $5 \%$ de significância, para a possível estacionariedade da série Brasil, a não rejeição da estatística $\phi_{3}$ não permite afirmar de maneira inequívoca que a mesma seja estacionária, de forma que parece razoável considerá-la não estacionária.

A estatística $\tau_{\beta \tau}$ revela que todas as séries não possuem tendência, dada a não significância dos resultados.

Para as séries Bangkok, Brasil e Argentina os resultados das estatísticas $\phi_{2}$ permitem rejeitar a hipótese de nulidade para o termo de intercepto, embora a mesma hipótese não seja confirmada pelos resultados da estatística $\tau_{\alpha \mu}$. Neste caso pode-se verificar se estas séries são integradas fazendo-se uso dos modelos II e III nas segundas diferenças, os quais confirmam que as mesmas são integradas de ordem um.

No caso da série Uruguai, a não rejeição das hipóteses de nulidade para $\phi_{2}, \phi_{3}$ e $\tau_{\alpha \mu}$ indicam que o modelo associado ao processo gerador dos dados pode ser representado pelo modelo III, o qual indica ser a mesma integrada de ordem um.

Neste caso, todas as séries de arroz abordadas podem ser consideradas nas relações de cointegração. 
Tabela 4 - Resultados dos testes de raiz unitária para as séries de arroz, 1990/01 -1998/06.

\begin{tabular}{|c|c|c|c|c|c|c|c|}
\hline \multirow[t]{2}{*}{ MODELO } & \multirow{2}{*}{$\begin{array}{l}\text { ESTATIS- } \\
\text { TICA }\end{array}$} & \multicolumn{2}{|c|}{ VALORES CRITICOS } & \multirow{2}{*}{$\underset{\text { (3) }}{\text { Bangkok }}$} & \multirow{2}{*}{$\begin{array}{l}\text { Brasil }^{1} \\
\text { (1) }\end{array}$} & \multirow{2}{*}{$\begin{array}{l}\text { Uruguai }^{1} \\
\text { (1) }\end{array}$} & \multirow{2}{*}{$\underset{(2)}{\text { Argentina }}$} \\
\hline & & $(5 \%)$ & $(1 \%)$ & & & & \\
\hline \multirow[t]{4}{*}{ I } & $\tau_{\tau}$ & $-3,45$ & $-4,04$ & $-3,35$ & $-3,83^{*}$ & $-2,05$ & $-3,56$ \\
\hline & $\phi_{3}$ & 6,49 & 8,73 & 3,75 & 5,08 & 1,48 & 4,41 \\
\hline & $\tau_{\beta \tau}$ & 2,79 & 3,53 & $-2,26$ & $-2,69$ & $-1,62$ & $-3,34$ \\
\hline & $\phi_{2}$ & 4,88 & 6,50 & $5,61^{*}$ & $7,56^{* *}$ & 2,13 & $6,60^{* *}$ \\
\hline \multirow[t]{3}{*}{ II } & $\tau_{\mu}$ & $-2,59$ & $-3,51$ & $-2,41$ & $-2,71$ & $-1,26$ & $-1,34$ \\
\hline & $\tau_{\alpha \mu}$ & 2,54 & 3,22 & 2,40 & 2,67 & 1,22 & 1,32 \\
\hline & $\phi_{1}$ & 4,71 & 6,70 & 2,93 & 3,74 & 0,88 & 0,91 \\
\hline III & $\tau$ & $-1,95$ & $-2,60$ & 1,20 & 1,09 & $-0,53$ & $-0,24$ \\
\hline II nas $\Delta \Delta Y_{t}$ & $\tau_{\tau}$ & $-3,45$ & $-4,04$ & $-4,49^{* 2}$ & $-9,98$ & - & $-6,19^{*}$ \\
\hline III nas $\Delta \Delta Y_{t}$ & $\tau$ & $-1,95$ & $-2,60$ & $-4,51$ & $-10,05^{* *}$ & $-7,89^{* *}$ & $-6,21$ \\
\hline
\end{tabular}

"O valor entre parênteses indica o número de defasagens utilizado na regressão.

* indica que se rejeita a hipótese nula a $5 \%, * *$ indicam rejeição a $1 \%$.

Os valores críticos encontram-se em Dickey e Fuller (1981, p. 1062-1063).

Fonte: dados da pesquisa.

\subsection{Especificação dos modelos}

A análise empírica parte da formulação exposta em (13), com quatro equações para o caso do milho, 4 equações para o caso do arroz, 2 equações para as séries de algodão (período 1990/98) e 5 equações para as séries de algodão (período $1994 / 97)^{70}$.

Como já mencionado no capítulo anterior, os testes de cointegração devem ser acompanhados de testes de diagnósticos de resíduos que permitam selecionar o melhor modelo que deverá determinar as relações de cointegração dentre modelos alternativos diferenciados segundo os elementos determinísticos que contenham. Tais elementos determinísticos referem-se tanto àqueles associados à parte correspondente ao curto-prazo, expressa em diferenças (número de defasagens), como àqueles associados ao longo-prazo, expressa em níveis (constante e tendência determinística).

\footnotetext{
${ }^{70}$ Cada equação diz respeito a uma das séries de preços, dentre aquelas selecionadas como sendo integradas de ordem 1 , segundo as indicaçōes dos testes de raiz unitária.
} 
A eleição do número de defasagens em cada modelo foi realizada tendo em conta o critério de Akaike para modelos VAR e partiu de um conjunto de 12, 8, 6, 3 e 2 defasagens como suscetíveis de serem consideradas na especificação dos modelos para as séries de milho, algodão (1990/98) e arroz; para o caso do algodão (séries 1994/97) partiu-se de um conjunto de 6, 3 e 2 defasagens. Os resultados encontram-se na tabela A.l do apêndice e indicam que, para o milho, o critério de Akaike é minimizado com 3 defasagens, para o arroz o é com 12 defasagens, para o algodão modelo (séries 1990/98) com 2 defasagens e para algodão modelo (séries 1994/97) com 6 defasagens.

Para, auxiliar a escolha dos componentes determinísticos fez-se uso do Critério de Pantula. Este procedimento permite testar conjuntamente o número de vetores de cointegração e os componentes determinísticos do modelo adequado para especificação. Como este procedimento utiliza apenas a estatística traço para indicar o número de vetores de cointegração, neste trabalho os resultados do mesmo foram entendidos como tendo um caráter orientativo para eleição do modelo. Tal critério indicou o modelo que inclui somente uma constante no espaço de cointegração como mais adequado para as séries de milho e arroz; para as séries de algodão 1994/97 temse a indicação de um modelo que inclui uma constante no curto prazo e no espaço de cointegração. No caso do modelo para as séries de algodão (1990/98) o critério aponta para a provável não existência de relações de cointegração entre as mesmas.

Modelos alternativos foram também simulados para cada caso, incluindo modelos de onze variáveis dummies estacionais centradas, com vistas a levar em consideração a presença de estacionariedade no espaço de curto prazo ${ }^{71}$. Dentre os modelos alternativos selecionou-se, aquele que apresentou melhor performance nos testes de diagnósticos dos resíduos. Os modelos das séries de arroz e algodão (1990/98) permaneceram com a inclusão de 11 varíaveis dummies sazonais centradas.

\footnotetext{
${ }^{71}$ Este procedimento também foi utilizado por Johansen e Juselius ( 1992) para dados quadrimestrais, In e Inder (1997) e Lopes, A.I. (1996) para dados mensais.
} 
A seguir são feitas algumas considerações sobre os testes de diagnósticos de resíduos para os modelos adotados nos casos de cada produto ${ }^{72}$. Algumas das estatísticas de diagnósticos de resíduos para as séries abordadas neste estudo estão apresentadas nas tabelas 5 a 8; os testes e as propriedades investigadas são: a) testes multivariados baseados no princípio de Lagrange para autocorrelação serial dos resíduos; b) testes univariados para heterocedasticidade condicional autoregressiva dos resíduos $(\mathrm{ARCH}), \mathrm{e} \mathrm{c})$ testes para normalidade .

Os resultados do teste ARCH indicam que heterocedasticidade constitui problema somente no modelo para algodão (1990/98). Nos demais modelos, os testes para normalidade dos resíduos mostram 3 estatísticas muito elevadas, quais sejam, preços de Chicago e Roterdã no modelo proposto para as séries de milho, e preços do Brasil no modelo para as séries algodão de 1990/98. ${ }^{73}$

Uma possível explicação para este comportamento pode ser encontrada em Johansen e Juselius (1992), segundo a qual, tomando-se o exemplo do modelo para as séries de milho, os preços de Chicago e Roterdã possivelmente poderiam explicar variações de preço no Brasil e na Argentina mas não vice-versa, ou seja, estes mercados não são suficientes para explicar variações de preços daqueles. Isto é uma indicativa de que os preços' de Chicago e Roterdã podem ser variáveis exógenas fracas para os parâmetros de interesse (o que será discutido adiante). Esta razão torna os desvios de normalidade menos importantes, segundo Johansen e Juselius (1992, p. 219).

Com respeito à significância do teste multivariado para normalidade (modelos para milho e algodão 1990/98), indicando ser possível rejeitar a hipótese de erros normalmente distribuídos, está associada com a presença de erros não normais em uma ou mais variáveis, como discutido no parágrafo acima.

\footnotetext{
${ }^{72}$ Deve-se ressaltar que estes testes de diagnósticos de resíduos são feitos juntamente com os testes de cointegração, mas estão sendo discutidos anteriormente à estes para obter-se uma apresentação mais didática dos resultados.

${ }^{73}$ Sobre a não normalidade dos resíduos do modelo para algodão, adiante fícará evidenciado que não há relações de cointegração entre as séries envolvidas neste modelo.
} 
Tabela 5 - Testes sobre a correta especificação do modelo proposto para as séries de milho (3 defasagens).

Estatística $^{\text {I1 }}$ Argentina Chicago Roterdä Brasil

\begin{tabular}{|c|c|c|c|c|c|}
\hline Testes univariados & V.C $(5 c$ & & & & \\
\hline $\mathrm{ARCH}^{3 /}$ & 5,99 & 0,51 & 0,00 & 0,39 & 5,53 \\
\hline NORMALIDADE $^{4 /}(8)$ & 15.51 & 10.52 & $34,91^{*}$ & $17,68 *$ & 12,13 \\
\hline DESVIOS-PADRĀO & - & 0,064 & 0,062 & 0,048 & 0,066 \\
\hline Testes multivariados $^{5 /}$ & \multicolumn{5}{|c|}{$\operatorname{LM}(1)^{6 /}=29,00^{*} \mathrm{LM}^{\pi /}(4)=8,94$ Normalidade $=64,77^{*}$} \\
\hline Valores Críticos $(5 \%)$ & \multicolumn{2}{|c|}{$\operatorname{LM}(1)$ e $\operatorname{LM}(4)=26,30$} & \multicolumn{3}{|c|}{ Normalidade: 15,51} \\
\hline
\end{tabular}

Fonte: Dados da pesquisa.

I As fórmulas e distribuição das estatísticas estăo em Hansen e Juselius (1995, p. 72-76) .

2 Valor Crítico (testes univariados).

3 Teste para heterocedasticidade condicional autoregressiva dos resíduos (ARCH). O valor crítico corresponde a uma distribuição $\chi^{2}$ com tantos graus de liberdade quanto o número de defasagens do modelo.

4 Os valores críticos correspondem a uma $\chi^{2}$ com $2 \mathrm{p}$ graus de liberdade.

5 Nesta linha estão os valores das estatísticas dos testes multivariados, na linha abaixo, os valores críticos.

6 Teste de Multiplicador de Lagrange para correlação serial dos resíduos (para a $1^{\text {it }} \mathrm{e}$ 4! autocorrelações). Os valores criticos correspondem a uma $\chi^{2} \operatorname{com} \mathrm{p}^{2}$ graus de liberdade.

\section{Tabela 6 - Testes sobre a correta especificação do modelo para as séries de arroz (12 defasagens e 11 dummies sazonais)}

\begin{tabular}{|c|c|c|c|c|c|}
\hline Estatística & & Tailândia & Brasil & Uruguai & Argentina \\
\hline Testes univariados & \multicolumn{5}{|l|}{ V.C $(5 \%)^{2 /}$} \\
\hline $\mathrm{ARCH}^{3 /}$ & 21,03 & 13,31 & 6,05 & 8,72 & 21,72 \\
\hline NORMALIDADE $^{4 /}(8)$ & 12,59 & 0,156 & 0,704 & 0,701 & 1,167 \\
\hline DESVIOS-PADRĀO & - & 0,037 & 0,049 & 0,032 & 0,036 \\
\hline Testes multivariados $^{5}$ & \multicolumn{5}{|c|}{$\operatorname{LM}^{6}(1)=23,510 \quad \mathrm{LM}^{6}(4)=16,479$ Normalidade $=4,77$} \\
\hline V. C. $(5 \%)$ t. Multivariados: & \multicolumn{2}{|c|}{$\operatorname{LM}(1)$ e $\operatorname{LM}(4)=26,30$} & \multicolumn{3}{|c|}{ Normalidade: 15,51} \\
\hline
\end{tabular}

\footnotetext{
Fonte: Dados da pesquisa.

As fórmulas e distribuição das estatísticas estão em Hansen e Juselius (1995, p. 72-76) .

Valor Crítico (testes univariados).

Teste para heterocedasticidade condicional autoregressiva dos resíduos (ARCH). O valor crítico corresponde a uma $\chi 2$ com tantos graus de liberdade quanto o número de defasagens do modelo. Os valores críticos correspondem a uma $\chi 2$ com $2 p$ graus de liberdade.

5 Nesta linha estão os valores das estatísticas dos testes multivariados, na linha abaixo, os valores críticos.

6 Teste de Multiplicador de Lagrange para correlação serial dos resíduos (para a $1^{\text {it }} 4^{\text {a }}$ autocorrelações).

Os valores críticos correspondem a uma $\chi^{2}$ com $\mathrm{p}^{2}$ graus de liberdade.
} 
Tabela 7 - Testes sobre a correta especificação do modelo proposto para as séries de algodão 1994/98 ( 6 defasagens).

\begin{tabular}{|c|c|c|c|c|c|c|}
\hline Estatistica & & Indice $B$ & Nyork & Brasil & Argentina & Paraguai \\
\hline Testes univariados & V.C $(5 \%)^{2}$ & & & & & \\
\hline $\mathrm{ARCH}^{3 /}$ & 12,59 & 6,103 & 3,987 & 3,597 & 1,663 & 1,921 \\
\hline NORMALIDADE $^{4 /}(8)$ & 18,31 & 5,702 & 3,495 & 6,778 & 1,066 & 10,592 \\
\hline DESVIO-PADRĀO & & 0,015 & 0,012 & 0,011 & 0,027 & 0,019 \\
\hline Testes multivariados ${ }^{5 /}$ & \multicolumn{2}{|c|}{$\operatorname{LM}(1)^{6 / 2}=24,95$} & $\operatorname{LM}^{6}(4)=$ & 4,60 & \multicolumn{2}{|c|}{ Normalidade $=22,45$} \\
\hline Valores críticos $(5 \%)$ & \multicolumn{3}{|c|}{$\operatorname{LM}(1)$ e $\operatorname{LM}(4)=26,30$} & & \multicolumn{2}{|c|}{ Normalidade $=37,65$} \\
\hline
\end{tabular}

Fonte: Dados da pesquisa

As fórmulas e distribuição das estatísticas estão em Hansen e Juselius (1995, p. 72-76) .

Valor Crítico testes univariados.

Teste para heterocedasticidade condicional autoregressiva dos resíduos (ARCH). O valor crítico

corresponde a uma $\chi 2$ com tantos graus de liberdade quanto o número de defasagens do modelo.

Os valores críticos correspondem a uma $\chi 2$ com $2 p$ graus de liberdade.

Nesta linha estão os valores das estatísticas dos testes multivariados, na linha abaixo, os valores críticos.

Teste de Multiplicador de Lagrange para correlação serial dos resíduos (para a $1^{i t}$ e $4^{i !}$ autocorrelações).

Os valores críticos correspondem a uma $\chi^{2} \operatorname{com} \mathrm{p}^{2}$ graus de liberdade.

Tabela 8 - Testes sobre a correta especificação do modelo

VAR para as séries de algodão 1990/98

(2 defasagens, 11 dummies sazonais)

\begin{tabular}{|c|c|c|c|}
\hline Estatística" & & Indice $B$ & Brasil \\
\hline Testes univariados & V.C $(5 \%)^{2 T}$ & & \\
\hline $\mathrm{ARCH}^{3 /}$ & 7,81 & $8,35^{\circ}$ & $12,088^{*}$ \\
\hline NORMALIDADE ${ }^{4 /}(8)$ & 9,48 & 6,05 & $43,020^{\circ}$ \\
\hline DESVIO-PADRĀO & & 0,059 & 0,082 \\
\hline
\end{tabular}

Testes multivariados ${ }^{5 /} \quad \mathrm{LM}^{0 /}(1)=19,88, \mathrm{LM}^{6 /}(4)=7,67$

Normalidade $=61,59^{\circ}$

V. C. $(5 \%)$ t. Multivariados: $\operatorname{LM}(1)$ e $\operatorname{LM}(4)=16,92 \quad$ Normalidade $=12,59$

\footnotetext{
Fonte: Dados da pesquisa

As fórmulas e distribuição das estatísticas estão em Hansen e Juselius (1995, p. 72-76) .

Valor Crítico (testes univariados).

3 Teste para heterocedasticidade condicional autoregressiva dos resíduos (ARCH). O valor crítico corresponde a uma $\chi 2$ com tantos graus de liberdade quanto o número de defasagens do modelo.

4 Os valores críticos correspondem a uma $\chi 2 \operatorname{com} 2 p$ graus de liberdade.

5 Nestas duas linhas estão os valores das estatísticas dos testes multivariados, na linha abaixo. os valores críticos.

6 Teste de Multiplicador de Lagrange para correlação serial dos resíduos (para a $1^{\stackrel{a}{ }} \mathrm{e}$ $4^{2}$ autocorrelaçōes). Os valores críticos correspondem a uma $\chi^{2} \operatorname{com} \mathrm{p}^{2}$ graus de liberdade.
} 
Resumindo tem-se, para o caso das séries de milho, a especificação de um modelo com quatro equações, contendo cada uma delas um intercepto no espaço de cointegração e 3 defasagens. Para o arroz tem-se um modelo também com quatro equações contendo um intercepto no espaço de cointegração, 12 defasagens e 11 variáveis dummies sazonais centradas. No caso das séries para algodão modelo para 1994/97 tem-se um modelo com 5 equações, cada uma com 6 defasagens contendo um intercepto nas relações de cointegração e no espaço de curto prazo. No caso do modelo contento as séries de algodão para o período 1990/98 tem-se 2 equações com 2 defasagens. 11 dummies sazonais centradas e um intercepto nas relações de cointegração.

\subsection{Testes de cointegração}

Nas tabelas 9 a 12 estão apresentados os resultados das estatísticas $\lambda$ Max e teste traço. a partir dos quais pode-se obter indicação da existência e o número de vetores de cointegração $\beta$ existentes em cada modelo, os quais estabelecem as relações estacionárias de longo prazo entre as variáveis não estacionárias. Os autovetores (eigenvalues) associados com as combinações de variáveis I(1) estão na primeira coluna de cada tabela, ordenados de maior para menor.

A determinação do número de vetores de cointegração é feita a partir da seguinte sequiência de testes: começa-se testando $H_{0}: \mathrm{r}=0$ frente à alternativa $H_{a}: \mathrm{r}=1$. Se, por exemplo, o valor de $\lambda$-Max for superior ao valor crítico tem-se indicação de rejeição da hipótese nula e não existência de nenhum vetor de cointegração. Se a estatística traço também indicar para a rejeição da hipóteses nula, isso é uma indicação de que existe, no máximo, zero vetores de cointegração.

Na sequiência, passa-se a testar $H_{0}: \mathrm{r}=1$ frente à alternativa: $H a: \mathrm{r}=2$. Caso o valor do $\lambda$-Max seja inferior ao valor crítico, tem-se a indicação de que se aceita a presença de exatamente um vetor de cointegração sendo o próximo passo verificar se a estatística traço também aponta para, no máximo um vetor de cointegração. 
Os resultados apresentados nas tabelas 9 e 10 revelam que o sistema formado pelos preços de milho e arroz contêm um único vetor de cointegração (relação de equilíbrio de longo prazo) o que é equivalente a dizer-se que, em cada sistema de preços, uma coluna de $\beta$ forma uma combinação linear independente e estacionária de variáveis em $Z_{t}$, junto com 3 vetores não estacionários $(p-r)$ no caso do milho e 3 no caso do arroz. Já no caso do modelo para as séries de algodão, período 1994/97 (tabela 11), o teste traço aponta para a existência de, no máximo, três vetores de cointegração, enquanto o teste $\lambda$-max revela a existência de exatamente quatro vetores de cointegração. Como parece haver algum consenso de que o teste traço apresenta maior robustez em termos da distribuição de resíduos relativamente ao teste de máximo traço ${ }^{74}$.

Por outro lado, no modelo para as séries de algodão (1990/98) os resultados da tabela 12 mostram que não existe relação de cointegração entre as duas séries consideradas, quais sejam, Brasil e Índice B.

Tabela 9 - Teste de cointegração para as séries de milho.

\begin{tabular}{cccccc}
\hline $\mathbf{H}_{\mathbf{0}} \mathbf{r}$ & $\begin{array}{c}\text { Auto valor } \\
\text { (eigenvalue) }\end{array}$ & $\begin{array}{c}\lambda \text {-Max } \\
\text { Valor Crítico } \\
(\mathbf{9 5 \% )}\end{array}$ & $\begin{array}{c}\text { Teste } \\
\text { traço }\end{array}$ & $\begin{array}{c}\text { Valor Crítico } \\
(\mathbf{9 5 \% )}\end{array}$ \\
\hline 0 & 0,3985 & $50,33^{*}$ & 28.14 & $77,84^{*}$ & 53.12 \\
1 & 0,1462 & 15,65 & 22.00 & 27,52 & 34.91 \\
2 & 0,1033 & 10,80 & 15.67 & 11,86 & 19.96 \\
3 & 0,0107 & 1,07 & 9.24 & 1,07 & 9.24 \\
\hline
\end{tabular}

1/ Os valores críticos são de Osterwald-Lenum (1992).

\footnotetext{
${ }^{74}$ De acordo com Harris, 1995, p. 89, Cheung e Lai (1993) realizaram experimentos de Monte Carlo e comprovaram que entre os dois testes de máxima verossimilhança de Johansen, o teste traço apresenta melhor performance em termos de distribuição dos resíduos relativamente ao teste $\lambda$-max. [ Cheung, T.W; Lai, K.S. Finite Samples size of Johansen's for cointegration, Oxford Bulletin of Economics and Statistics, n.55, p.313-328, 1993].
} 
Tabela 10 - Teste de cointegração para as séries de arroz.

\begin{tabular}{cccccc}
\hline $\mathbf{H}_{\mathbf{0}:} \mathbf{r}$ & $\begin{array}{c}\text { Auto valor } \\
\text { (eigenvalue) }\end{array}$ & $\lambda$-Max & $\begin{array}{c}\text { Valor Crítico } \\
\mathbf{( 9 5 \% )}\end{array}$ & $\begin{array}{c}\text { Teste } \\
\text { traço }\end{array}$ & $\begin{array}{c}\text { Valor Crítico }^{\text {I/ }} \\
\mathbf{9 5 \% )}\end{array}$ \\
\hline 0 & 0,3191 & $34,60^{*}$ & 28.14 & $63,31^{*}$ & 53.12 \\
1 & 0,1781 & 17,65 & 22.00 & 28,71 & 34.91 \\
2 & 0,0859 & 8,08 & 15.67 & 11,06 & 19.96 \\
3 & 0,0326 & 2,98 & 9.24 & 2,98 & 9.24 \\
\hline
\end{tabular}

1/ Os valores críticos são de Osterwald-Lenum (1992).

Tabela 11 - Teste de cointegração para as séries de algodão (1994/97).

\begin{tabular}{cccccc}
\hline $\mathbf{H}_{\mathbf{0}:} \mathbf{r}$ & $\begin{array}{c}\text { Auto valor } \\
\text { (eigenvalue) }\end{array}$ & $\begin{array}{c}\lambda \text {-Max } \\
\text { Valor Crítico } \\
(\mathbf{9 5 \%})\end{array}$ & $\begin{array}{c}\text { Teste } \\
\text { traço }\end{array}$ & $\begin{array}{c}\text { Valor Crítico }^{\text {II }} \\
\mathbf{( 9 5 \% )}\end{array}$ \\
\hline 0 & 0,9394 & $117,77^{*}$ & 33,46 & $229,87^{*}$ & 68,52 \\
1 & 0,7926 & $66,06^{*}$ & 27,07 & $112,10^{*}$ & 47,21 \\
2 & 0,5202 & $30,85^{*}$ & 20,97 & $46,03^{*}$ & 29,68 \\
3 & 0,2950 & $14,68^{*}$ & 14,07 & 15,19 & 15,41 \\
4 & 0,0119 & 0,50 & 3,76 & 0,50 & 3,76 \\
\hline
\end{tabular}

1/ Os valores críticos são de Osterwald-Lenum (1992).

Tabela 12 - Teste de cointegração para as séries de algodão (1990/98).

\begin{tabular}{cccccc}
\hline $\mathbf{H}_{\mathbf{0}} \mathbf{r}$ & $\begin{array}{c}\text { Auto valor } \\
\text { (eigenvalue) }\end{array}$ & $\begin{array}{c}\lambda \text {-Max } \\
\text { Valor Crítico }\end{array}$ & $\begin{array}{c}\text { Teste } \\
(\mathbf{9 5 \% )}\end{array}$ & $\begin{array}{c}\text { Valor Crítico }^{\text {II }} \\
\text { traço }\end{array}$ & $\mathbf{( 9 5 \% )}$ \\
\hline 0 & 0,022 & 2,20 & 15,67 & 2,41 & 19,96 \\
1 & 0,002 & 0,21 & 9,24 & 0,21 & 9,24 \\
\hline
\end{tabular}

1/ Os valores críticos são de Osterwald-Lenum (1992). 
Sobre o número de relações de cointegração encontradas, para Dickey, Jansen e Thornton (1994), vetores de cointegração podem ser entendidos como representando restrições sobre o sistema econômico, as quais impõem limitações ao movimento das variáveis no longo prazo. Assim, mais vetores de cointegração tornam o sistema mais estável. É, portanto, desejável que um sistema econômico seja estável em tantas direções quanto possível. Segundo aqueles autores,

"(...) se há $p-l$ vetores de cointegração (e uma tendência comum sendo
$p$ o número de variáveis ), há $p-l$ direções onde a variância é finita e
uma direção onde é infinita. Por outro lado, se há somente um vetor de
cointegração, o sistema pode flutuar em torno de $p-l$ direções
independentes mas só uma é estável. Quanto menor o número de
vetores de cointegração, menos restrita está a relação de longo prazo;
assim, outras coisas contantes, parece desejável ter muitos vetores de
cointegração. (...)" (Dickey, Jansen e Thornton 1994, p.23).

Não fosse pelo fato das séries contidas no modelo para algodão (1994/97) contemplarem um horizonte temporal relativamente curto, poder-se-ia argumentar que os resultados dos sistemas formados pelas séries de algodão neste modelo estariam apontando que estes tornam-se integrados e estáveis a partir de 1994, dado que o número de relações de cointegração aumentou para 3 relativamente ao modelo formado com as séries 1990/98, onde não se constatam relações de cointegração. $^{75}$

As tabelas 13 a 15 apresentam os elementos dos vetores de cointegração $\left(\beta_{\mathrm{i}}\right)$ estimados, assim como os coeficientes de ajustamento $\left(\alpha_{\mathrm{i}}\right)$ associados aos vetores de cointegração em cada uma das equações. Os vetores de cointegração foram submetidos a uma normalização matemática, a qual consiste em simples divisão de cada linha pelo elemento escolhido (esta escolha é arbitrária e unicamente tem por objetivo realçar a relação existente entre as variáveis). Tal procedimento é baseado em 
um dado valor de $r$ (número de relações de cointegração) escolhido segundo as indicações dos testes traço e $\lambda$-Max.

$\mathrm{Na}$ parte inferior de cada tabela encontram-se a matriz $\Pi$ estimada, obtida mediante o produto das matrizes $\alpha$ e $\beta$ ( $\left.\alpha \beta^{\prime}\right)$, restringindo o número de vetores de cointegração segundo as indicações dos testes de cointegração. Os elementos destas matrizes medem, em cada uma das equações, o efeito combinado do vetor de cointegração e seus coeficientes de ajustamento.

Tabela 13 - Vetor ·de cointegração $(\beta)$, coeficientes de ajustamento $(\alpha)$

e a matriz $\Pi$. Séries de milho 1990/98.

\begin{tabular}{lccccc}
\hline & PArgentina & PChicago & Proterdã & PBrasil & Constante \\
\hline$\beta^{\prime \prime}$ & 28,780 & 7,674 & 20,829 & 1,000 & $-1,876$ \\
$\alpha$ & 0,011 & $-0,005$ & $-0,005$ & 0,018 & $-\cdots-\cdots$ \\
\hline Matriz $\Pi$ & PArgentina & PChicago & Proterdã & PBrasil & Constante \\
\hline Pargentina & $-0,305$ & 0,081 & 0,221 & 0,011 & $-0,020$ \\
PChicago & 0,146 & $-0,039$ & $-0,106$ & $-0,005$ & 0,010 \\
Proterdã & 0,137 & $-0,037$ & $-0,099$ & $-0,005$ & 0,009 \\
PBrasil & $-0,511$ & 0,136 & 0,370 & 0,018 & $-0,033$ \\
\hline
\end{tabular}

77 Vetor de cointegração normalizado pelo elemento que acompanha o preço FOB Brasil.

\footnotetext{
${ }^{75}$ Neste ponto da análise deve-se considerar que o número de séries de preços é diferente de um período para outro. De 1990 a 1998 tem-se 3 séries para algodāo (sendo uma estacionária), enquanto de 1994 a 1998 tem-se 5 séries (uma estacionária).
} 
Tabela 14 - Vetor de cointegração $(\beta)$, coeficientes de ajustamento $(\alpha)$ e a matriz $\Pi$. Séries de arroz 1990/98.

\begin{tabular}{cccccc}
\hline & PBangkok & PBrasil & Puruguai & PArgentina & Constante \\
\hline$\beta^{1 \prime}$ & $-1,075$ & $-1,244$ & 1,000 & 0,531 & 2,134 \\
$\alpha$ & 0,172 & 0,177 & $-0,253$ & 0,286 & $\cdots$ \\
\hline Matriz $\Pi$ & PBangkok & PBrasil & PUruguai & PArgentina & Constante \\
\hline Pbangkok & $-0,185$ & $-0,214$ & 0,172 & 0,091 & 0,367 \\
Pbrasil & $-0,190$ & $-0,220$ & 0,177 & 0,094 & 0,378 \\
Puruguai & 0,253 & 0,293 & $-0,236$ & $-0,125$ & $-0,503$ \\
Pargentina & 0,286 & 0,332 & $-0,267$ & $-0,141$ & $-0,569$ \\
\hline
\end{tabular}

${ }^{T /}$ Vetor de cointegração normalizado pelo elemento que acompanha o preço FOB Uruguai.

Tabela 15 - Vetores de cointegração $(\beta)$, coeficientes de ajustamento $(\alpha)$ a matriz П. Séries de algodão 1994/97.

\begin{tabular}{lccccc}
\hline & PÍndiceB & PNIorque & Pbrasil & Pargentina & PParaguai \\
\hline$\beta^{1 /}$ & 1,000 & $-1,091$ & 0,238 & $-0,525$ & 0,219 \\
$\beta^{2 /}$ & $-1,121$ & 1,000 & 0,483 & 0,914 & $-0,965$ \\
$\beta^{3 /}$ & $-0,019$ & 0,353 & $-0,003$ & 1,000 & $-1,110$ \\
$\alpha$ & 0,473 & 1,418 & $-0,325$ & 0,463 & 1,445 \\
$\alpha$ & $-0,235$ & $-1,022$ & $-0,996$ & $-0,482$ & 0,410 \\
$\alpha$ & 0,244 & $-0,073$ & 0,231 & $-0,136$ & 0,624 \\
\hline Matriz $\Pi$ & PÍndiceB & PNIorque & Pbrasil & Pargentina & PParaguai \\
\hline PÏndiceB & 0,733 & $-0,666$ & $-0,002$ & $-0,220$ & 0,061 \\
PNIorque & 2,564 & $-2,594$ & $-0,155$ & $-1,751$ & 1,378 \\
PBrasil & 0,786 & $-0,560$ & $-0,559$ & $-0,509$ & 0,634 \\
PArgentina & 1,006 & $-1,035$ & $-0,122$ & $-0,819$ & 0,717 \\
PParaguai & 0,974 & $-0,947$ & 0,540 & 0,240 & $-0,771$ \\
\hline
\end{tabular}

${ }^{T /}$ Vetor de cointegração normalizado pelo elemento que acompanha o preço do mercado Liverpool Índice B; em $2 / \mathrm{a}$ nomalização é feita para Nova Iorque e, em 3/ para Argentina. 
As equações (26) a (30) a seguir, indicam as formulações dos vetores de cointegração (as relações de equilíbrio de longo prazo $\beta^{\prime} \mathbf{Z}_{\mathbf{t}-\mathbf{k}}=\mathbf{0}$ ), as quais foram obtidas a partir da normalização dos vetores de cointegração pelos preços do Brasil e Uruguai, respectivamente para os modelos de milho, arroz, e normalização pelas séries Índice B, Nova Iorque e Argentina para as relações de cointegração no segundo modelo de algodão (séries 1994/97) .

$$
\begin{aligned}
& P_{\text {Brasil }}=1,876-28,780 \mathrm{P}_{\text {Argentina }}-7,674 \mathrm{P}_{\text {Chicago }}-20,829 \mathrm{P}_{\text {Roterdā }} \\
& P_{\text {Uruguai }}=-2,134+1,075 \mathrm{P}_{\text {Bangkok }}+1,244 \mathrm{P}_{\text {Brasil }}-0,531 \mathrm{P}_{\text {Argentina }} \\
& P_{\text {IndiceB }}=1,091 \mathrm{P}_{\text {Niorque }}-0,238 \mathrm{P}_{\text {Brasil }}+0,525 \mathrm{P}_{\text {Argentina }}-0,219 \mathrm{P}_{\text {Paraguai }} \\
& P_{\text {Nova Iorque }}=1,121 \mathrm{P}_{\text {IndiceB }}-0,483 \mathrm{P}_{\text {Brasil }}-0,914 \mathrm{P}_{\text {Argentina }}+0,965 \mathrm{P}_{\text {Paraguai }} \\
& P_{\text {Argentina }}=0,019 \mathrm{P}_{\text {IndiceB }}-0,353 \mathrm{P}_{\text {Nova Iorque }}-0,003 \mathrm{P}_{\text {Brasil }}+1,110 \mathrm{P}_{\text {Paraguai }}
\end{aligned}
$$

As relações acima refletem o equilíbrio de longo prazo entre as variáveis. Interpretar os vetores de cointegração $(\beta)$ acima, assim como os coeficientes de ajustamento $(\alpha)$ neste momento da análise pode ser arriscada por dois motivos: em primeiro lugar para poder extrair alguma conclusão sobre a magnitude dos coeficientes é necessário testar sua significância estatística. Em segundo lugar, as relações acima representam relações estáveis de equilíbrio de longo prazo e, por isso, não permitem interpretações sobre os ajustamentos de curto prazo (dados por valores defasados tanto das variáveis dependentes quanto das demais).

Neste sentido, testes de significância dos parâmetros $\beta$ assim como sobre a velocidade de ajustamento $(\alpha)$ entre distintas variáveis em direção a uma situação de equilíbrio, serão formulados a seguir. 


\subsection{Testes sobre os parâmetros $\beta$}

Os testes de hipóteses sobre os parâmetros beta e alfa são considerados muito importantes por envolverem a discussão das relações econômicas estruturais no modelo de longo prazo, ou seja, permitem fazer considerações sobre o grau com que as variáveis interagem (a importância de cada variável no processo de ajustamento) e a velocidade com a qual as mesmas reagem a desequilíbrios (a dimensão da velocidade de ajustamento).

Os testes de hipóteses sobre os parâmetros beta ou combinações destes parâmetros encontram-se apresentados e discutidos em Johansen e Juselius (1990 e 1992), não têm sido muito aplicados e, principalmente, discutidos empiricamente em pesquisas recentes. Em trabalhos que analisam integração de mercados, In e Inder (1997) realizam apenas um tipo de teste e Lopes, A.I.(1996) estende os testes para os parâmetros alfa e beta; com outras abordagens pode-se citar o trabalho de Larue e Babula (1994).

Para Larue e Babula (1994), os parâmetros $\beta$ podem ser considerados como representando a importância relativa com a qual cada variável, no espaço delimitado pelas $r$ relações de cointegração, deve convergir como um sistema que reequilibra ou "corrige o erro", por exemplo, após um choque no sistema.

Neste contexto, esta pesquisa testa duas hipóteses-chave associadas àqueles parâmetros: $i$ ) teste para a relevância de cada variável no espaço de cointegração (ou para exclusão da variável do espaço de cointegração) e, ii) dentre as variáveis cujos testes da hipótese anterior apontaram para a permanência no espaço de cointegração, testa-se se o grau de integração entre os mercados é suficientemente elevado para poder-se concluir que os mesmos estão perfeitamente integrados e, portanto, que se cumpre a Lei do Preço Único.

A integração perfeita de mercados admite uma interpretação de longo prazo que pode ser expressa de duas maneiras distintas, segundo Lopes, A.I.(1996). A primeira consiste em definir mercados perfeitamente integrados aqueles nos quais existe um preço representativo para o conjunto de mercados como conseqüência das ações de 
arbitragem de preços no mercado internacional. Neste sentido, Goodwin (1992b) assinala que a existência de múltiplos vetores de cointegração apoia a existência de um único preço e, portanto, a Lei do Preço Único. Um único vetor de cointegração, pelo contrário e tal como se obteve neste trabalho em 2 dos 4 casos tratados, implica que o comportamento de qualquer um dos preços pode ser explicado em termos dos preços restantes do sistema e portanto não é completamente representativo do conjunto, segundo o mesmo autor acima.

A segunda interpretação consiste em definir mercados perfeitamente integrados como aqueles nos quais uma variação no preço de um mercado transmite-se de maneira complẹta ao resto dos mercados, no longo prazo. Como indicado na discussão do referencial teórico (páginas 37 e 38), em um contexto de duas variáveis como na expressão (6) viu-se que o cumprimento da LPU em sua forma absoluta exige que o coeficiente $\beta$ [ $\beta_{1}$ em (1) e $\beta$ em (6)] seja igual a um. Se em um contexto de múltiplas variáveis, por exemplo no caso do modelo para arroz neste trabalho, o equilíbrio de longo prazo pode ser representado pela seguinte expressão:

$$
\beta^{\prime} Z_{t}=\beta_{B a n} P_{B a n . t}+\beta_{B r} P_{B r, t}+\beta_{U r u} P_{\text {cru. }}+\beta_{A r k} P_{A r g, t}
$$

onde os subscritos associados aos coeficientes de longo prazos e preços, $\mathrm{Ban}, \mathrm{Br}$, Uru e Arg referem-se respectivamente aos coeficientes e preços das séries de Bangkok, Brasil, Uruguai e Argentina.

Se por exemplo quer-se verificar se variações nos preços do mercado de Buenos Aires, Argentina são transmitidas por completo e na mesma proporção ao mercado brasileiro, tem-se que a elasticidade do segundo em relação ao primeiro deve ser igual a um:

$$
\frac{\partial P_{\text {Brasil }} \quad P_{\text {Argentinut }}}{\partial P_{\text {Argentina }}} P_{\text {Brasil }}=1
$$


De (31) e levando em consideração que as variáveis estão expressas em logarítmos temse:

$$
\frac{\partial P_{\text {Brasil }}}{\partial P_{\text {Argentina }}} \frac{P_{\text {Argentina }}}{P_{\text {Brasil }}}=\frac{-\beta_{\text {Argentina }}}{\beta_{\text {Brasil }}}=1
$$

e portanto, a perfeita integração dos mercados será constatada se $\beta_{\text {Argentina }}=-\beta_{\text {Brasil }}$, de acordo com a discussão apresentada no capítulo anterior (5.1.5).

Neste caso o vetor de cointegração pode ser representado da seguinte forma $\left(*,-1,{ }^{*}, 1, *\right)$, onde os parâmetros estão expostos nas mesmas posições colocadas na primeira linha da tabela 14 (página 113), os asteriscos indicando que os correspondentes parâmetros $\beta_{i}$ não estão restritos. No contexto, a perfeita integração entre pares de mercados é testada a partir da seguinte hipótese geral:

$$
\mathrm{H}_{0}: \beta_{i}=-\beta_{j} \quad(\mathrm{i} \neq \mathrm{j})
$$

Neste caso, as duas restrições sobre $\beta$ compreendem uma restrição de homogeneidade $(k=1) ; p=5$ contando com o termo constante e $s=4$ (o número de coeficientes não restritos).

A matriz $\mathbf{H}^{*}$ para o caso particular do teste para integração perfeita entre os mercados Argentina e Brasil é expressa, de acordo com (20) no capítulo anterior como:

$$
H^{*}=\left[\begin{array}{rrrr}
0 & 1 & 0 & 0 \\
-1 & 0 & 0 & 0 \\
0 & 0 & 1 & 0 \\
1 & 0 & 0 & 0 \\
0 & 0 & 0 & 1
\end{array}\right]
$$


Uma forma alternativa de representar esta hipótese consiste em formular o vetor de cointegração da forma $(0,-1,0,1, *)$. A diferença entre esta e a formulação anterior está em que, nesta, os demais parâmetros de cointegração foram igualados a zero (o asterisco representa o termo constante). Neste caso, o teste aponta se a relação existente entre os preços dos mercados Argentina e Brasil formam uma relação estacionária em si mesma, podendo formar um sistema à parte no qual não intervenham os outros preços. Este teste é efetuado mediante a definição da seguinte matriz $\mathbf{H}^{*}$ :

$$
H^{*}=\left[\begin{array}{rr}
0 & 0 \\
-1 & 0 \\
0 & 0 \\
1 & 0 \\
0 & 1
\end{array}\right]
$$

A hipótese formulada em (34) foi testada para todos os possíveis pares de preços e nas duas versões: sem e com restrições sobre o resto dos parâmetros. Os resultados estão nas tabelas 17 a 20.

Analisando inicialmente a significância dos parâmetros beta (as hipóteses $\left.\beta_{\mathrm{i}}=0\right)$ no modelo para algodão (1994/97) cujos resultados estão apresentados na porção inferior da tabela 16 , verifica-se que os resultados permitem rejeitar a hipótese de nulidade dos parâmetros $\beta$ associados a todas as séries. Isto significa que as 5 séries de preços consideradas influenciam os sinais de mercado e participam das 3 direções onde a variância é finita (representadas pelas 3 relações de cointegração, apontadas segundo os testes da tabela 11 (página 110). 
Tabela 16 - Testes sobre a significância dos parâmetros $\beta$ e perfeita integração entre pares de mercados. Séries de algodão 1994/97.

\begin{tabular}{lcccc}
\hline & \multicolumn{2}{c}{ Sem restrições } & \multicolumn{2}{c}{ Com restrições } \\
\cline { 2 - 5 } $\mathbf{H}_{\mathbf{0}}$ & Razão de & Valor Crítico & Teste Razão de & Valor Crítico \\
\hline$\beta_{\text {ÍndiceB }}=-\beta_{\text {Nlorque }}$ & $13,25^{*}$ & 7,81 & 5,51 & 5,99 \\
$\beta_{\text {ÍndiceB }}=-\beta_{\text {Brasil }}$ & $86,10^{*}$ & 7,81 & $6,21^{*}$ & 5,99 \\
$\beta_{\text {Nlorque }}=-\beta_{\text {Brasil }}$ & $77,75^{*}$ & 7,81 & $19,03^{*}$ & 5,99 \\
$\beta_{\text {Argentina }}=-\beta_{\text {Brasil }}$ & $39,18^{*}$ & 7,81 & $6,66^{*}$ & 5,99 \\
$\beta_{\text {Argentina }}=-\beta_{\text {Parag. }}$ & $55,99^{*}$ & 7,81 & 4,53 & 5,99 \\
$\beta_{\text {ÍndiceB }}=-\beta_{\text {Paraguai }}$ & $74,38^{*}$ & 7,81 & $20,79^{*}$ & 5,99 \\
$\beta_{\text {ÍndiceB }}=-\beta_{\text {Argentina }}$ & $44,23^{*}$ & 7,81 & $21,36^{*}$ & 5,99 \\
$\beta_{\text {Nlorque }}=-\beta_{\text {Paraguai }}$ & $74,74^{*}$ & 7,81 & $29,53^{*}$ & 5,99 \\
$\beta_{\text {NIorque }}=\beta_{\text {Argentina }}$ & $82,20^{*}$ & 7,81 & $17,99^{*}$ & 5,99 \\
$\beta_{\text {ÍndiceB }}=0$ & $79,86^{*}$ & 7,81 & - & - \\
$\beta_{\text {Brasil }}=0$ & $60,45^{*}$ & 7,81 & - & - \\
$\beta_{\text {Nlorque }}=0$ & $87,64^{*}$ & 7,81 & - & - \\
$\beta_{\text {Argentina }}=0$ & $57,51^{*}$ & 7,81 & - & - \\
$\beta_{\text {Paraguai }}=0$ & $40,26^{*}$ & 7,81 & - & - \\
\hline
\end{tabular}

1/ Restringindo os demais parâmetros a zero.

Fonte: dados da pesquisa.

Nos modelos de milho e arroz, por outro lado (tabelas 17 e 18), os resultados não permitem rejeitar a hipótese de que são nulos os parâmetros $\beta$ associados às séries Brasil e Chicago no modelo de milho, assim como o parâmetro $\beta$ associado à série Argentina no modelo de arroz (tabela 18). Isto indica que os movimentos de preços no Brasil e no mercado futuro de Chicago no caso do milho, 
assim como o preço da Argentina no modelo para arroz, não têm relevância na determinação do equilíbrio de longo prazo determinado pelo conjunto de preços contemplados em cada caso. Significa também que choques nos preços destes mercados não são capazes de promover ajustamentos nos demais preços considerados na análise. Portanto, tais variáveis podem ser excluídas das relações de longo prazo.

Especificamente no caso do modelo para milho, o resultado não significativo do parâmetro $\beta_{\mathrm{i}}$ à série Chicago a princípio não é esperada. Entretanto, observando-se a figura 13 (página 71), que mostra a evolução conjunta dos preços de milho para as séries consideradas nesta pesquisa, vê-se que os preços da série Chicago seguem um padrão bastante distinto dos demais de 1990 até o final de 1993, e, a partir de então, segue acompanhando o padrão de evolução dos demais preços, principalmente Argentina e Estados Unidos. Tal evolução diferenciada dos preços no

Tabela 17 - Testes sobre a significância dos parâmetros $\beta$ e perfeita integração entre pares de mercados. Séries de milho 1990/98.

\begin{tabular}{lcl}
\hline \multicolumn{1}{c}{$\mathbf{H}_{\mathbf{0}}$} & $\begin{array}{c}\text { Razão de } \\
\text { Verossimilhança }\end{array}$ & $\begin{array}{c}\text { Valor Crítico } \\
\chi^{2} \mathbf{5 \% )}\end{array}$ \\
\hline$\beta_{\text {Argen }}=-\beta_{\text {Rotterd }}{ }^{\prime \prime}$ & 0,55 & 3,84 \\
$\beta_{\text {Argen }}=-\beta_{\text {Rotterd. }^{2 /}}$ & 2,08 & 5,99 \\
\hline$\beta_{\text {Argen }}=0$ & $22,13^{*}$ & 3,84 \\
$\beta_{\text {Brasil }}=0$ & 0,07 & 3,84 \\
$\beta_{\text {Chicago }}=0$ & 1,07 & 3,84 \\
$\beta_{\text {Roterd. }}=0$ & $5,34^{*}$ & 3,84 \\
\hline
\end{tabular}

Obs: testes de hipóteses para perfeita integração envolvendo Brasil e Chicago (como ex. $\beta_{\text {Brasil }}=-\beta_{\text {Chicago }}$ ) não foram realizados porque não fazem sentido nesta abordagem. dado que ambas as séries podem ser excluídas da relação de longo prazo.

// Sem restrições sobre os parâmetros beta não testados.

2/ Restringindo os demais parâmetros $\beta$ a zero.

Fonte: dados da pesquisa. 
mercado futuro de Chicago nos primeiros quatro anos da década pode explicar, ao menos em parte, a não significância do parâmetro associado à mesma.

Por outro lado, a não significância do parâmetro beta associado à série Brasil pode estar revelando a pequena importância deste país no estabelecimento do padrão de equilíbrio de longo prazo dos preços no mercado internacional de milho. $\mathrm{O}$ Brasil, apesar de ocupar a terceira posição no ranking dos países maiores produtores de milho, tem recorrido às importações para completar suas necessidades de consumo interno. Entretanto, os volumes importados por este país não permitem caracterizá-lo como um grande importador no mercado mundial, de forma que os níveis de preços deste país não cọntêm informações relevantes para os demais mercados e, em conseqüência, para o estabelecimento do padrão de equilíbrio de longo prazo no mercado internacional de milho, representado pelas séries abordadas neste trabalho.

\section{Tabela 18 - Testes sobre a significância dos parâmetros $\beta$ e perfeita integração} entre pares de mercados. Séries de arroz 1990/98 .

\begin{tabular}{|c|c|c|}
\hline $\mathbf{H}_{0}$ & $\begin{array}{c}\text { Razão de } \\
\text { Verossimilhança }\end{array}$ & $\begin{array}{c}\text { Valor Crítico } \\
\chi^{2}(5 \%)\end{array}$ \\
\hline$\beta_{\text {Argentina }}=0$ & 0,76 & 3,84 \\
\hline$\beta_{\text {Brasil }}=0$ & $9.09 *$ & 3,84 \\
\hline$\beta_{\text {Bangkok }}=0$ & $16,28^{*}$ & 3,84 \\
\hline$\beta_{\text {Uruguai. }}=0$ & $6,84^{*}$ & 3,84 \\
\hline$\beta_{\text {Bangkok }}=-\beta_{\text {Brasil }}{ }^{1}$ & $12,77^{*}$ & 3,84 \\
\hline$\beta_{\text {Bangkok }}=-\beta_{\text {Uruguai }}{ }^{1 /}$ & 0,05 & 3,84 \\
\hline$\beta_{\text {Bangkok }}=-\beta_{\text {Uruguai }}^{2 /}$ & $24,73^{*}$ & 7,81 \\
\hline$\beta_{\text {Uruguai }}=-\beta_{\text {Brasil }}{ }^{1 /}$ & 0,17 & 3,84 \\
\hline$\beta_{\text {Uruguai }}=-\beta_{\text {Brasil }}^{2}$ & $25,68^{*}$ & 7,81 \\
\hline
\end{tabular}

1/ Sem restrições sobre os parâmetros beta não testados.

2/ Restringindo os demais parâmetros $\beta$ a zero.

Fonte: dados da pesquisa. 
No modelo para as séries de arroz, a indicação de exclusão do parâmetro relativo à série Argentina pode estar associada a dois aspectos. Um primeiro diz respeito à pequena participação deste país como exportador no comércio mundial de arroz menos de $2 \%$, (como discutido no capítulo 4) - de forma que as considerações feitas com relação à importância do mercado brasileiro no estabelecimento do padrão de equilíbrio no mercado mundial de milho são válidas também neste caso. Um segundo aspecto diz respeito ao comportamento dos preços de exportação argentinos a partir de 1996. Como mostra a figura 7 (página 59), a partir deste ano o preço de exportação argentino permanece constante em torno de $\mathrm{R} \$ 15,00 / 30 \mathrm{Kg}$, não acompanhando as pequenas oscilações nos preços das demais séries.

Tendo analisado a significância de cada parâmetro $\beta$, na seqüência analisa-se a hipótese de integração perfeita entre pares de mercados, tal como discutido em (34) neste capítulo. Estes testes estão na parte superior das mesmas tabelas anteriormente mencionadas e relaciona pares de mercados para os quais os testes para os parâmetros $\beta$ individuais mostraram significância.

No modelo para as séries de algodão 1994/97 (parte superior da tabela 16), os resultados conduzem à rejeição das hipóteses de integração perfeita entre todos os pares de mercados. Ou seja, sem a imposição de restrições, as relações de paridade apresentadas não constituem, por si, relações de equilíbrio estável sem a intervenção dos preços dos demais mercados. Por outro lado, quando são colocadas restrições zero aos demais parâmetros $\beta$ não testados (quarta coluna da tabela 16), os resultados evidenciam que os pares de séries Índice B/ Nova Iorque e Argentina/Paraguai tendem a constituir soluções de equilíbrio estável, indicando que, possivelmente, os preços destes pares de mercados caminham de forma muito próxima sinalizando para possível integração entre os pares de mercados.

No caso do modelo envolvendo as séries de preços para milho, os resultados da tabela 17 não permitem rejeitar a hipótese de perfeita integração entre os mercados exportadores da Argentina e Roterdã. Este resultado não é alterado quando se coloca restrição zero sobre os demais parâmetros, o que equivale a dizer-se que, para estes mercados, a Lei do Preço Único é perfeitamente verificada. Dado que o mercado 
de Roterdã é um importante "mercado central" de onde saem exportações de commodities para o mundo todo e, por outro lado, a Argentina também tem posição de destaque nas exportações mundiais de milho, destacando-se com a terceira posição no ranking dos maiores exportadores mundiais, é razoável obter-se integração perfeita entre este mercados .

Para o modelo que relaciona as séries de preços de arroz (tabela 18), as indicações são de perfeita integração entre os pares de mercado tailandês e uruguaio e os mercados brasileiro e uruguaio. Nestes dois casos, a hipótese de perfeita integração entre estes pares de mercados indicados acima não constituem equilíbrio estável por si, mas somente se verifica num contexto onde interagem os demais preços, uma vez que, quando se impõe restrição zero aos demais parâmetros não testados, a possibilidade de integração perfeita entre aqueles dois pares de mercados deixa de ser indicada, como mostra a tabela 18 .

Tais resultados para os mercados de arroz parecem razoáveis, pois, considerando que o Brasil é um dos grandes importadores mundiais de arroz e o principal consumidor dos excedentes do Mercosul, é possível que seu mercado seja integrado ao mercado do Uruguai, seu principal fornecedor.

Por outro lado, sendo o mercado tailandês o principal exportador mundial de arroz e o mercado uruguaio, também exportador, porém pequeno no contexto do mercado mundial. é também natural que as variações nos preços do mercado tailandês transmitam-se por completo e no longo prazo, para o mercado uruguaio, constituindo mercados integrados, porém não perfeitamente.

\subsection{Testes sobre os parâmetros $\alpha$}

Um dado parâmetro $\alpha$, associado a uma determinada variável preço, no presente trabalho, proporciona dois tipos de informação dependendo de sua significância e magnitude. A significância indica que a variável preço à qual o parâmetro 
$\alpha$ está associado, não é exógena fraca com relação ao parâmetro de longo prazo, $\beta$. A exogeneidade fraca é um conceito relativo e significa que a variável não reage ante a mudanças na relação de equilíbrio no curto prazo, com vistas a restabelecer o equilíbrio de longo prazo.

A magnitude do parâmetro $\alpha$ indica a velocidade de ajuste da respectiva variável preço a ele associada em direção ao equilíbrio de longo prazo. Um valor pequeno de alfa significa que, ante a uma situação de desequilíbrio transitório, a respectiva variável preço ajusta-se lentamente para retornar ao padrão de equilíbrio de longo prazo. Um coeficiente elevado, pelo contrário, indica que este se produz rapidamente (Larue e Babula, 1994).

É possível realizar-se dois tipos de testes sobre os parâmetros alfa. O primeiro diz respeito ao teste sobre a significância individual dos parâmetros alfa, ou, alternativamente, o teste de exogeneidade fraca, de acordo com (24) no capítulo 5. A hipótese nula é formulada como:

$$
H_{0}: \quad \alpha_{\mathrm{i}}=0
$$

sendo a matriz $\mathbf{B}^{176}$ para o caso particular do teste $H_{0}$ : $\alpha_{\mathrm{Brasil}}=0$ no modelo para arroz :

$$
\mathrm{B}^{\prime}=\left[\begin{array}{llll}
0 & 1 & 0 & 0
\end{array}\right]
$$

Uma segunda possibilidade de teste consiste em verificar a igualdade dos parâmetros $\alpha_{i}$, ou seja, a igualdade na velocidade de resposta das distintas variáveis a uma dada situação de desequilíbrio de curto prazo no processo de ajuste ao padrão de longo prazo. A hipótese nula é formulada como:

$$
H_{0}: \quad \alpha_{\mathrm{i}}=\alpha_{\mathrm{j}} \quad(\mathrm{i} \# \mathrm{j})
$$

Tomando por exemplo, o modelo para as séries de arroz, a matriz $\mathbf{B}^{\prime}$ para testar, a hipótese $H_{0}: \alpha_{\text {Brasil }}=\alpha_{\text {Argentina }}$ adota a seguinte forma:

${ }^{76}$ Definida em 5.1.6. no capítulo 5. 


$$
B^{\prime}=\left[\begin{array}{llll}
0 & 1 & 0 & -1
\end{array}\right]
$$

Os resultados estão apresentados nas tabelas 19 a 21 e serão discutidos a seguir.

No modelo para algodão (1994/97), os testes de significância para os parâmetros $\beta$ apresentados anteriormente revelaram que todas as séries participam do equilíbrio de longo prazo isto é, cada variável cointegrada tem importância significativa no sistema como um todo e participa do processo de convergência ou correção para o nível de equilíbrio de longo prazo.

Tabela 19 - Testes sobre a significância dos parâmetros $\alpha$.

Séries de algodão 1994/97.

\begin{tabular}{ccc}
\hline & Sem restrições sobre os parâmetros $\beta$ \\
\cline { 2 - 3 } $\mathbf{H}_{\mathbf{0}}$ & Razão de & Valor Crítico \\
\hline$\alpha_{\text {IndiceB }}=0$ & $9,71^{*}$ & $\chi^{2}(5 \%)$ \\
$\alpha_{\text {Brasil }}=0$ & $48,16^{*}$ & 7,81 \\
$\alpha_{\text {Nlorque }}=0$ & $63,45^{*}$ & 7,81 \\
$\alpha_{\text {Argentina }}=0$ & $7,13^{*}$ & 7,81 \\
$\alpha_{\text {Paraguai }}=0$ & $40,16^{*}$ & 7,81 \\
\hline$\alpha_{\text {IndiceB }}=\alpha_{\text {NIorque }}$ & $36,83^{*}$ & 7,81 \\
$\alpha_{\text {ÍndiceB }}=\alpha_{\text {Brasil }}$ & $26,71^{*}$ & 7,81 \\
$\alpha_{\text {ÍndiceB }}=\alpha_{\text {Paraguai }}$ & $20,42^{*}$ & 7,81 \\
$\alpha_{\text {Nyork }}=\alpha_{\text {Paraguai }}$ & $34,86^{*}$ & 7,81 \\
$\alpha_{\text {Brasil }}=\alpha_{\text {NIorque }}$ & $71,85^{*}$ & 7,81 \\
\hline
\end{tabular}


Os testes para a significância dos parâmetros alfa evidenciam que, exceto pela variável preço da Argentina, pode-se dizer que todas as demais séries contidas no modelo participam ativamente do processo de correção de erro a um dado desequilíbrio transitório, o que é mostrado pela rejeição da hipótese de valor zero para os respectivos

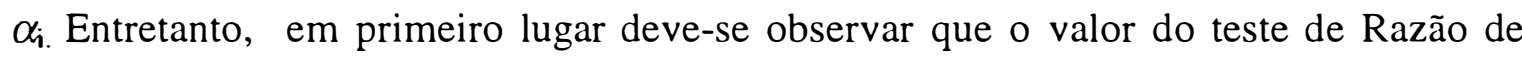
Verossimilhança encontra-se bastante próximo ao nível de significância. Em segundo lugar, se esta série de fato for exogéna isto indica que, embora participe das relações de cointegração, não se ajusta a desequilíbrios de curto prazo provenientes de variações nos níveis da demais séries de preços. Ou seja, os demais mercados não são suficientes para explicar as variações nos preços de exportação deste país.

Neste modelo, como as demais séries que participam da relação de cointegração não são exógenas fracas, pode-se testar a igualdade de velocidade de ajuste a um dado desequilíbrio, entre pares de séries de mercados. Os resultados apontam para a rejeição da hipótese de igualdade de reação dos preços em direção ao equilíbrio de longo prazo a velocidades estatisticamente idênticas para todos os pares de mercados apontados (tabela 19).

No modelo para o padrão de equilíbrio de longo prazo para os preços de milho, as variáveis Chicago e Roterdã se revelam exógenas fracas, uma vez que não foi possível rejeitar a hipótese de nulidade para os respectivos parâmetros alfa (tabela 20). Este resultado foi previsto quando se discutiu, na análise dos testes sobre a especificação do modelo VAR escolhido (tabela 5 e discussão na pagina 105), a possível razão da significância apresentada nos testes de normalidade para as séries Chicago e Roterdã.

No caso da série Chicago, os testes anteriores sobre a significância dos parâmetros beta revelaram que esta série não tem importância significativa no estabelecimento do padrão de equilíbrio de longo prazo desta (tabela 17), podendo ser excluída da relação de cointegração. Dessa forma, é natural que os testes para os parâmetros alfa agora revelem que a série Chicago não responde a desequilíbrios transitórios nos preços dos demais mercados contemplados na análise.

O mercado de Roterdã representa um importante ponto de referência para exportações e importações mundiais, tendo a análise anterior revelado que este mercado 
participa das relações de cointegração. No caso da não significância do parâmetro alfa para este mercado, uma interpretação possível para este resultado está em afirmar que, dada sua importância no mercado mundial de milho, influencia os níveis dos preços nos demais mercados (podendo até mesmo conduzí-los) mas não é, entretanto, significativamente afetado por estes e não se ajusta ante a desequilíbrios transitórios provenientes dos mesmos.

O teste $\alpha_{\text {Chicago }}=\alpha_{\text {Roterdã }}$ objetiva responder se Chicago e Roterdã podem ser conjuntamente consideradas exógenas, dado que cada série o é individualmente. O resultado evidencia que não se pode rejeitar esta proposição.

Tabela 20 - Testes sobre a significância dos parâmetros $\alpha$ (testes de exogeneidade) Séries de milho 1990/98.

\begin{tabular}{|c|c|c|c|c|c|c|}
\hline \multirow[t]{2}{*}{$\begin{array}{r}\mathrm{Se} \\
\mathrm{o}\end{array}$} & \multicolumn{2}{|c|}{$\begin{array}{l}\text { em restrições sobre } \\
\text { os parâmetros } \beta\end{array}$} & \multicolumn{2}{|c|}{$\begin{array}{c}\text { Com restrição } \\
\beta_{\text {Argentina }}=-\beta_{\text {Roterdã }}\end{array}$} & \multicolumn{2}{|c|}{$\begin{array}{l}\text { Outras restrições } \\
\text { (identificadas abaixo da } \\
\text { tabela) }\end{array}$} \\
\hline & $\begin{array}{l}\text { Razão de } \\
\text { Jerossimilhança }\end{array}$ & $\begin{array}{l}\text { Valor } \\
\text { Crítico } \\
\chi^{2}(5 \%)\end{array}$ & $\begin{array}{c}\text { Razão de } \\
\text { Verossimilhança }\end{array}$ & $\begin{array}{l}\text { Valor } \\
\text { Crítico } \\
\chi^{2}(5 \%)\end{array}$ & $\begin{array}{c}\text { Razão de } \\
\text { Verossimilhança }\end{array}$ & $\begin{array}{l}\text { Valor } \\
\text { Crítico } \\
\chi^{2}(5 \%)\end{array}$ \\
\hline$\alpha_{\text {Argen }}=0$ & $6,17^{*}$ & 3,84 & $6,39^{*}$ & 5,99 & - & - \\
\hline$\alpha_{\text {Brasil }}=0$ & $18,60^{*}$ & 3,84 & $19,46^{*}$ & 5,99 & $18,91^{* 2 /}$ & 5,99 \\
\hline$\alpha_{\text {Chicago }}=0$ & 1,48 & 3,84 & 1,76 & 5,99 & $2,01^{3 /}$ & 5,99 \\
\hline$\alpha_{\text {Rotterdam }}=0$ & 2,34 & 3,84 & 3,10 & 5,99 & - & - \\
\hline$\alpha_{\text {Brasil }}=\alpha_{\text {Argenti }}$ & $15,06^{*}$ & 5,99 & 3,74 & 5,99 & $15,10^{21}$ & 5,99 \\
\hline$\alpha_{\text {Chicago }}=\alpha_{\text {Roter }}$ & 1,97 & 5,99 & 2,38 & 5,99 & $2,62^{3 /}$ & - \\
\hline
\end{tabular}

$2 /$ Condicionado a $\beta_{\text {Brasil }=0}$.

3/ Condicionado a $\beta_{\text {Chicago } 0}$.

Neste mesmo modelo outro resultado surpreendente refere-se ao valor bastante significativo do teste $\alpha$ para a série Brasil, dada a informação a priori de que esta série poderia ser excluída do espaço de cointegração $\left(\beta_{\text {Brasil }}=0\right.$ na tabela 17$)$. Com o 
valor de beta estatisticamente zero para esta série, deve-se entender que não há uma relação de longo prazo entre os níveis de preços neste país e nos demais. Já a hipótese de exogeneidade fraca é claramente rejeitada (e com o maior valor absoluto para alfa indicando maior velocidade de ajuste a desequilíbrios transitórios). Isto indica que, embora esta série não seja significativamente importante no processo de ajuste ao padrão de equilíbrio de longo prazo, os níveis dos preços no Brasil reagem com relativa eficiência a desequilíbrios transitórios que ocorrem nos níveis dos demais preços considerados nesta análise ${ }^{77}$.

Como o Brasil tem importado volumes significativos de milho de origem Argentina, testa-se se ambos os mercados retornam a um dado desequilíbrio a velocidades estatisticamente iguais após um choque no sistema. A significância do resultado aponta para a rejeição desta proposição, o que é razoável pois estes mercados não constituem mercados integrados. Por outro lado, a Argentina é um importante exportador, enquanto o Brasil se configura como importador mas sem muito destaque no mercado mundial desta commodity.

No caso do mercado mundial de arroz envolvendo as séries abordadas neste trabalho, os resultados apontam para a significância dos parâmetros alfa associados às séries de preços Uruguai e Argentina, revelando que estas não são exógenas fracas para os parâmetros de interesse, enquanto as séries Brasil e Bangkok apresentam-se como exógenas fracas com respeito ao equilíbrio de longo prazo. Estes resultados não variam quando se introduzem restrições de perfeita integração entre os mercados Tailandês e Uruguaio e entre este último e o brasileiro (estas proposições não foram rejeitadas e estão na tabela 18 ).

Dito de outra forma, pode-se dizer que a Argentina, mesmo não sendo significativamente importante no estabelecimento do equilíbrio de longo prazo para o

\footnotetext{
${ }^{77}$ Esta aparente contradição, revelada pela não significância do parâmetro beta (indicando exclusão da variável das relações de cointegração) e significância do parâmetro alfa (indicando resposta significativa da variável a desequilíbrios transitórios) também foi encontrada e devidamente justificada no trabalho desenvolvido por Larue e Babula (1994).
} 
conjunto dos preços considerados $\left(\beta_{\text {Argentina }}=0\right.$ na tabela 18$)$, seu mercado reage aos desequilíbrios provenientes dos demais mercados.

Tabela 21 - Testes sobre a significância dos parâmetros $\alpha$ ( testes de exogeneidade). Modelo para as séries de arroz 1990/98.

\begin{tabular}{|c|c|c|c|c|c|}
\hline \multirow[b]{2}{*}{$\mathbf{H}_{\mathbf{0}}$} & \multicolumn{2}{|c|}{ Sem restriçōes sobre $\beta$} & $\begin{array}{c}\text { Restrição } \\
\beta_{\text {Bangkok }} \beta_{\text {Uruguai }}\end{array}$ & $\begin{array}{c}\text { Restrição }{ }^{I \prime} \\
\beta_{\text {Uruguai }}=-\beta_{\text {Brasil }}\end{array}$ & \\
\hline & $\begin{array}{c}\text { Razão de } \\
\text { Veros- } \\
\text { similhança }\end{array}$ & $\begin{array}{l}\text { Valor } \\
\text { Crítico } \\
\chi^{2}(5 \%) \\
\end{array}$ & $\begin{array}{c}\text { Razão de } \\
\text { Veros- } \\
\text { similhança }\end{array}$ & $\begin{array}{c}\text { Razão de } \\
\text { Veros- } \\
\text { similhança }\end{array}$ & $\begin{array}{c}\text { Valor } \\
\text { Crítico } \\
\chi^{2}(5 \%) \\
\end{array}$ \\
\hline$\alpha_{\text {Argentina }}=0$ & $5,04^{*}$ & 3,84 & $7,40^{*}$ & $6,32^{*}$ & 5,99 \\
\hline$\alpha_{\text {Brasil }}=0$ & 1,50 & 3,84 & 2,32 & 2,48 & 5,99 \\
\hline$\alpha_{\text {Bangkok }}=0$ & 2,26 & 3,84 & 3,65 & 4,51 & 5,99 \\
\hline$\alpha_{\text {Uruguai }}=0$ & $7,13^{*}$ & 3,84 & $7,18 *$ & $7,34 *$ & 5,99 \\
\hline
\end{tabular}

1/ Os valores críticos estāo na última coluna.

Já a exogeneidade dos preços Brasil e Bangkok significa que estes preços não são afetados por desvios que se produzem, no curto prazo, com respeito a situação de equilíbrio dos demais mercados. Tanto Tailândia (Bangkok) quanto Brasil têm pesos específicos notáveis no comércio internacional de arroz. A exogeneidade de Bangkok pode estar associada ao fato da Tailândia ser o maior produtor e exportador mundial de arroz e por isso marcar a pauta de evolução dos demais mercados sem reagir significativamente aos desequilíbrios transitórios provenientes destes mercados.

O mercado mundial de arroz é relativamente pequeno, pois os grandes produtores são também os maiores consumidores e os excedentes produzidos são relativamente curtos. Neste contexto, a quantidade de arroz demandada pelo mercado brasileiro tem importância significativa no padrão de equilíbrio dos preços no mercado mundial (evidência oferecida pela significância do teste para o parâmetro beta associado a esta série); entretanto a evidência de exogeneidade fraca para a série Brasil aponta que os preços brasileiros não respondem a desequilíbrios transitórios provenientes dos demais mercados e que os preços internos, no período compreendido pela análise, provavelmente foram mais sensíveis aos desequilíbrios internos do que aqueles associados aos desequilíbrios dos mercados internacionais. 


\section{CONCLUSÕES}

Este trabalho procurou estudar relações (espaciais) de preços existentes entre preços internos e externos para três commotidities agrícolas: o arroz, o milho e o algodão. Nos anos noventa, o Brasil tem atuado sistematicamente como importador líquido nos mercados internacionais destes três produtos para completar suas necessidades de abastecimento interno.

O estudo representa uma tentativa de discutir e obter-se inferências sobre em que medida os preços internos daquelas commodities têm acompanhado o padrão de longo prazo dos mercados externos numa década em que importantes transformações econômicas nos mercados externos e internos promoveram alterações na dinâmica de formação dos preços das commodities agropecuárias. As alterações ditadas pela abertura comercial e menor atuação do Estado nos mercados internos foram suficientes para possibilitar ações eficientes de arbitragem? É validada a Lei do Preço Único (LPU) e portanto são integrados os mercados considerados? Quais as implicações para as políticas setoriais internas?

Considerando os mercados estudados para aquelas três commodities, em geral os resultados obtidos não foram uniformes no sentido de oferecer suporte à hipótese de que as reduções das barreiras internas e externas ao comércio de commodities agrícolas, assim como a maior disponibilidade e qualidade das informações de mercado colocadas à disposição dos agentes econômicos, foram suficientes para tornar possível efetivar-se relações de integração entre os mercados internos brasileiros e os mercados externos considerados. Para maiores inferências, faz-se necessário particularizar a discussão para cada commodity abordada. 
Os resultados do procedimento de cointegração proposto por Johansen (1988) no caso do algodão (período 1990/98) não permitiram evidenciar relações de cointegração entre os preços do mercado brasileiro e os do mercado Liverpool Índice $\mathrm{B}^{78}$, podendo-se concluir, portanto, que no caso desta commodity, a LPU não é assegurada e os mercados não são integrados, no horizonte temporal compreendido pela análise.

Não se pode dizer, no caso do algodão, que a formação do preço interno é essencialmente doméstica. Nesta década, a significativa internalização de importações de importações, facilitadas pela oferta de financiamentos externos, bem como a menor atuação relativa dos instrumentos setoriais de sustentaçāo de preços no mercado interno, sem dúvida fizeram com que os agentes econômicos tomassem os vetores de preços externos como referência para a formação dos preços internos. Entretanto, apesar do maior intercâmbio comercial havido nesta década, ainda existe, no mercado brasileiro, uma grande rigidez para as ações de arbitragem de preços dos agentes econômicos internos, nos mercados externos. Um exemplo disto refere-se à dificuldade que têm as empresas brasileiras em situação patrimonial pouco favorável, para obtenção de carta de crédito com vistas à promoção de importações.

Em um segundo modelo formulado para as séries de algodão, envolvendo também os mercados da Argentina e Paraguai (período 1994/97), as três relações de cointegração obtidas entre os mercados considerados, sugerem uma possível maior estabilidade do sistema, assim como os testes de hipóteses também indicaram que, no período, o mercado brasileiro passa a participar endogenamente da formação do equilíbrio de longo prazo e a responder a desequilíbrios provenientes dos demais mercados. Entretanto, dado o período relativamente curto da análise, tais resultados devem ser vistos apenas como indicativos, carecendo de uma outra análise envolvendo um horizonte temporal maior para validá-los.

Diferentemente dos resultados obtidos no modelo para algodão, nos casos dos mercados de arroz e milho, obteve-se evidências de relações de interdependência de

\footnotetext{
${ }^{78}$ Neste modelo considerou-se três séries de preços: as duas mencionadas acima e Liverpool Índice A, esta excluída das relações de cointegração por revelar-se estacionária.
} 
preços entre os mercados, posto que os resultados indicariam a existência de um vetor de cointegração. Em ambos os casos, embora se tenha a indicação da presença de mecanismos de arbitragem entre mercados, a literatura recente não oferece respaldo para afirmar-se que um único vetor seja suficiente para dizer-se que os mercados são perfeitamente integrados. Na verdade, observa-se que o debate sobre a interpretação do número de vetores de cointegração e os parâmetros de longo prazo não se encontra totalmente consolidado; quando o objetivo da análise refere-se à verificação de integração de mercados, tanto as hipóteses a testar sobre os parâmetros de longo prazo, quanto a interpretação do número de vetores de cointegração como indicadores do grau de integração constituem temas ainda em evolução.

Os resultados dos testes de hipóteses no caso do modelo para milho, permitiram verificar que o vetor de cointegração estimado traz implícito uma relação de perfeita integração entre os mercados exportadores da Argentina e Roterdã. Estes indicaram também exclusão da série Brasil, significando dizer que este mercado não infuencia as outras variáveis no processo de ajuste ao equilíbrio de longo prazo, embora se tenha evidenciado uma reação deste mercado aos desequilíbrios provenientes dos demais. Em termos práticos, os resultados para o mercado brasileiro de milho permitem concluir que as variáveis associadas ao mercado interno ainda têm maior peso relativo na formação dos preços domésticos. Desta forma, no caso deste produto, pode-se negar a proposição inicial de que os preços externos estariam afetando sobremaneira o comportamento dos preços no mercado interno. Entretanto, o que difere qualitativamente dos resultados encontrados no caso do algodão é que, neste caso, foi possível evidenciar resposta do mercado interno à variações de preços de curto prazo provenientes dos mercados externos, o que é esperado em uma economia mais aberta às transações internacionais.

No caso do arroz a existência de arbitragem de preços, indicada na relação de cointegração, e adicionalmente, pela significância positiva da série Brasil no estabelecimento do padrão de equilíbrio de longo prazo (apontada pelos testes sobre os parâmetros beta), evidencia que de fato os preços internos têm relação com os preços do mercado intenacional, embora não respondam a desvios de curto prazo originários dos 
demais mercados. No mesmo modelo também ficou evidenciado que, no Mercosul, o mercado exportador uruguaio e o mercado importador brasileiro podem ser caracterizados como mercados integrados no longo prazo, integração esta que se verifica em um contexto caracterizado pelas interrelações com os demais preços.

As principais implicações de políticas agrícolas, à luz dos resultados obtidos, são de que, para os mercados internos de algodão (tomando por referência os resultados do modelo para o período 1990/98) e de milho, programas setoriais de políticas de preços e de abastecimento interno podem ainda desempenhar importante papel no equilíbrio dos mercados. Deve-se entender que esta proposição não eqüivale a dizer-se que existe espaço para iniciativas autônomas de políticas de preços e abastecimento. Ao contrário, é necessário levar em consideração as regras, os acordos e os preços do mercado internacional, posto que se obteve indicações de resposta dos mercados internos daqueles produtos aos incentivos e desequilíbrios do mercado externo $^{79}$.

Especificamente no caso das políticas internas de preços para o arroz, os resultados obtidos conduzem a concluir que a formulação destas deve tomar em consideração o Uruguai como extensão do mercado nacional. Mais ainda, os dois países podem obter significativos ganhos, no médio e longo prazos, se conseguirem elaborar uma política agrícola coordenada nos aspectos de produção, serviços de apoio e tecnologia. Tal conjugação de esforços pode ser importante tanto com vistas a melhor explorar as complementaridades entre estes países, quanto para, uma vez alcançada a recuperação da capacidade de autoabastecimento brasileira, tornar possível a inserção competitiva deste país no mercado internacional, como também galgar melhores posições, para o Uruguai, nas exportações mundiais de arroz.

Em função do intenso processo de ajuste porque passaram os mercados e os segmentos produtivos brasileiros das commodities abordadas nesta análise, deve-se entender os resultados obtidos nesta pesquisa de forma condicionada ao horizonte temporal e aos mercados considerados. Uma primeira limitação da pesquisa diz

\footnotetext{
${ }^{79}$ No caso do algodão tal constatação foi evidenciada nos testes de cointegração e hipóteses para o segundo período.
} 
respeito à impossibilidade de estudar séries adicionais de preços de outros países importantes nos mercados mundiais das commodities analisadas. Em segundo lugar, no caso do modelo formulado para o mercado de arroz, os resultados de integração obtidos apontam o mercado Uruguaio integrado ao mercado brasileiro, e também ao mercado tailandês, embora o mercado brasileiro não tenha se mostrado integrado à este último. Estas interrelações precisam ser melhor discutidas no contexto dos instrumentais teórico e metodológico utilizados.

A este respeito sugere-se a realização de pesquisas complementares ampliando-se o estudo para envolver os mercados de outras commodities, assim como utilização de instrumental complementar à análise de cointegração, fazendo-se uso da abordagem de funções resposta-impulso, as quais possibilitam separar a relação de longo-prazo da dinâmica de curto prazo e permitem o entendimento do impacto de choques no equilíbrio das variáveis. Pesquisas de aprofundamento também podem ser realizadas envolvendo: a) a questão da interpretação do número de vetores de cointegração como indicadores do grau de integração nos mercados, e b) maior reflexão sobre os desdobramentos das hipóteses sobre os parâmetros de longo prazo. 


\section{REFERÊNCIAS BIBLIOGRÁFICAS}

AGRIANUAL 99. São Paulo: FNP Consultoria e Comércio, 1999. 521 p.

ALMEIDA, C.O; Taxa de câmbio e determinantes da balança comercial de produtos agrícolas e agroindustriais no Brasil: 1961 a 1995. Piracicaba, 1998, 105p. Tese (Doutorado) - Escola Superior "Luiz de Queiroz" (ESALQ), Universidade de São Paulo.

ALÓ, R . MANDUCA, J. A . O arroz no Mercosul, situação atual e perspectivas. In: REUNIÃO NACIONAL DE PESQUISA DO ARROZ, (VI RENAPA), Goiânia, 1998. Goiânia, 1998.

ALSTON, J.M.; CARTER, G.A.; GREEN, R; PICH, D. Whither Armington Trade Models? American Journal of Agricultural Economics . v. 72, n. 2, p.455-467, may, 1991.

ANANIA, G.; McCALLA, A.F. Does Arbitraging Matter? Spacial Trade Models and Discriminatrory Trade Policies. American Journal of Agricultural Economics . v.73, n. 1, p.103-117, feb. 1991.

ARDENI, P.G. Does the Law of One Price really hold for commodituy prices? American Journal Agricultural Economics, v. 71. n.3, p.661- 669, 1989.

BACCHI, M.R.P. Integração , co-integração e modelo de correção de erro: Uma introdução. Piracicaba, ESALQ/USP, Depto de Economia e Sociologia Rural, 1996, 20p. (mimeo).

BACHA, C.J.C.; ROCHA, M.T. O crescimento da produção agropecuária brasileira no período de 1989 a 1996. Preços Agrícolas, p.6-8, junho de 1997 .

BAFFES, J. Some further evifence on the Law og One Price Still Holds. American Journal Agricultural Economics, n. 73 , p. 1264-1273, nov. 1991. 
BANERJEE, A.; DOLADO, J.J.; HENDRY, D.F.; GALBRAITH, J.W. Co-integration, error correction, and the econometric analysis of non-stationary data. Oxford: Oxford University Press, 1993, 329p.

BARBOSA, M.Z.. Transformação no mercado brasileiro de algodão e a influência de políticas comerciais. Informações Econômicas, v.26, n.2, p.11-21, fev. 1996.

BARROS, J.R.M.; GRAHAM, D.H. A agricultura brasileira e o problema da produção de alimentos. Pesquisa e Planejamento Econômico, vol. 8, n. 3, dez. 1978.

BAWDEN, D.L. A Spatial Price Equilibrium Model of International Trade. Journal of Farm Economics, v. 48, n. 4, p.862-874. nov. 1966.

BHASKARA RAO. Cointegration for applied economist. New York: St. Martins Prees. 1994. $231 \mathrm{p}$.

BECERRA. C. A. V. O mercado mundial de algodão. Revista de Política agrícola, ano VII, n. 1, p. 24-30, 1998.

BITTENCOURT, M.V.L. Formação de preços e caracterização do mercado de frango em São Paulo. Piracicaba, 1995, 161p. Dissertação (Mestrado) - Escola Superior "Luiz de Queiroz" (ESALQ), Universidade de São Paulo.

BUNGIORNO, J.; UUSIVUORI, J. The Law of One Price in the Trade of Forest Products: Co-integration tests for U.S. Exports of Pulp and Paper. Forest Science, v.38, n.3, p.539-553. 1992.

BURNQUIST, H.L. A proteção nominal da agricultura e o regime cambial 1972/94. Pesquisa e Planejamento Econômico, v. 27, n.2, p.433-458, agosto, 1997.

CAVALCANTI, M.A.F. Integração econômica e localização sob concorrência imperfeita. Prêmio BNDES de Economia, 20. Rio de Janeiro, 1997. 93p.

CHATFIELD, C. The analysis of Time Séries. An Introduction, 5. Ed., Londres: Chapman and Hall, 1996. 280p.

DAVID, M,B,A: NONNENBERG, M.J.B: Mercosul: Integração regional e comércio de produtos agrícolas. Rio de Janeiro. IPEA, jul 1997 (Textos para Discussão, n.494).

DICKEY, HANSEN, THORNTON. A primer on cointegration with na application to money and income. In: BHASKARA RAO (ed.). Cointegration for applied economist. New york: St. Martin's Press. 1994, cap. 2, p.9-45. 
DICKEY, D.A. : FULLER, W. A .. Distribution of estimators for autoregres e Time Séries with a unit root. Journal of American Statistical Association. n. 74, p.427$431,1979$.

DICKEY, D.A; FULLER, W. A . Likehood ratio estatistcs for autoregressive séries. Econometrica, v. 49., p.1057-1072, 1981.

ENDERS, W. Rats Handebook for Econometrics time séries. New York: John Wiley \& Sons, 1996, 204p.

ENGLE, R.F.; GRANGER, C.W.J. Cointegration and error correction: representation, estimation and testing. Econometrica, v.55, n.2. p.251-276, 1987.

FAMNON, M.D. BENSON, B.L. Spatial market integration. American Journal of Agricultural Economics, v. 72, n. 1, p.49-62, fev. 1990.

GASQUES, J.G.; CONCEIÇÃO, J.C.P.R. Crescimento e produtividade da agricultura brasileira. Rio de Janeiro, IPEA, jul. 1997 (Textos para Discussão, n.502).

GOODWIN,B.K.; T.L.GRENNES:M.K.WOHLGENANT. A revised teste of the Law of One price using racional expectations. Journal Agricultural Economics. v.72, n.3, p.682-693. 1990.

GOODWIN, B.K.; SCHROEDER. T.C. Cointegration tests and Spacial Price Linkages in Regional Catle markets. American Journal of Agricultural Economics. v.73, n.2, p. 452-464, may, 1991.

GOODWIN, B.k. Multivariate cointegration tests and the law of one price in international wheat markets. Review of Agriculral Economics. v.14, n.1, p.117-124, 1992a.

GOODWIN, B.K. Multivariate cointegration tests and the law of one price: a clarification and correction. Review of Agricultural Economics, v. 14, n.2, 1992 b.

GUIMARÃES. C.M., YOKOYAMA. L.P.: BRESEGHELO, F. Sistemas de produção de arroz de terras altas. In: REUNIÃO NACIONAL DE PESQUISA DO ARROZ, (VI RENAPA), Goiânia, 1998.

HAHN, L.M.D. A reforma tarifária de 1990: proteção nominal, proteção efetiva e impactos fiscais. Revista Brasileira de Comércio Exterior, n. 30, p. 35-41, jan.mar.1990. 
HANSEN, H.; JUSELIUS, K. Cats in Rats - Cointegration analysis of time series. Estima . Evanston, Illinois, 1995. 87 p.

HARRIS, R.I.D. Using Cointegration analysis in Econometric Modelling. London: Prentice Hall/Harvester Wheatsheaf, 1995. 176 p.

HOMEM DE MELO, F.B. Política comercial, tecnologia e preços de alimentos no Brasil. Estudos Econômicos, vol.11, n.2, jul. 1981.

HOLDEN, D. PERMAN, R. Unit roots and cointegration for the economist. In: BHASKARA RAO, (ed.). Cointegration. New York: St. Martin's Press, 1994, cap.3, p.47-112.

IN, F; INDER, B. Long-Run relationship between World Vegetable oil prices. The Australian Journal of Agricultural and Resource Economics. v. 41, n.4, p.455470. dec, 1997.

ISARD, P. How far we push the "Law of one Price"? American Economic Rev. v.67, n.5, p.942-948.1977.

JANK, M. S. O Brasil e o Comércio Mundial de Grāos. In: FAGUNES, M.H. (org.). Políticas Agrícolas e o Comércio Mundial de Grãos. Brasília, IPEA, 1994. p. 381-427. (Estudos de Política Agrícola, n.28).

JANK, M.S; LOPES. M.L. Intervenções do govemo nos mercados e exportação e importaçāo. In: BRUM. A . L. ; JANK, M.S; LOPES, M. R. A competitividade das cadeias agroindustriais no Mercosul. Ijui: UNIJUI, 1997, p.116- 172.

JOHANSEN, S. Satistical analysis of cointegration vectors. Journal of Economic Dynamics and Control. v.12, n.2/3. p.231-254, 1988.

JOHANSEN, S: JUSELIUS, K. Maximum likehood estimation and inference on cointegration - With application to demand for money. Oxford Bulletin of Economics and Statistcs, v. 52, n.2, p.169-210, 1990.

JOHANSEN, S: JUSELIUS, K. Testing strutural hypotheses in a multivariate cointegration analysis of the PPP and the UIP for UK. Journal of Econometrics, v. 53, p.211-244. 1992.

JOHANSEN, S; JUSELIUS, K. Identification of the long-run and the short-run structure. An application to the ISLM model. Journal of Econometrics, n.63, p.736, 1994. 
JOHANSEN, S. Likelihood - Based inference in cointegrated vector auto-regressive models. New York: Oxford University Press, 1996. 265p.

JUNG, C.; DOROODIAN, K. The Law of one Price for U.S. Softwood Lumber: A multivariate Cointegration Test. Forest Science, v. 40, n.4, p.595-600. 1994.

KARBUZ, S.; JUMAH, A. Cointegration and Commodity Arbitrage. Agribusiness. v.11, p. 235-243. may.-jun. 1995.

KOLSTAD, C.D.; BURRIS, A.E. Imperfectly Competitive Equilibro in International Commmodity Markets. American Journal of Agricultural Economics . v. 68, n.1, p. 27-36, fevereiro de 1986.

KUME, H. A liberalização das importações de produtos agrícolas: a experiência dos anos 90. Comércio Internacional e comercialização agrícola. In: TEIXEIRA, E.C; AGUIAR, D.R. (ed.) Viçosa: UFV, 1995. p.177-198.

KUME, H. A política de importação no Plano Real e a estrutura de proteção efetiva. Rio de Janeiro. IPEA, 1996 (Texto para discussão, n.432).

LARUE, B. BABULA, R.A. Evolving dynamic relations between the money supply and food-based prices in Canada and The United Sates. Canadian Journal of Agricultural Economics, v.42, p.159-176, 1994.

LEMME, M.C. A revisão tarifária de 1989. Revista Brasileira de Comércio Exterior, n. 26, nov.-dez. 1989, p. 33-39.

LIMA, S.M.A.: BURNQUIST, H.L. Lei do Preço Único no mercado internacional: Testes Empíricos para Exportações do Complexo Soja (Grãos e Farelo). In: XXX1V CONGRESSO BRASILEIRO DE ECONOMIA E SOCIOLOGIA RURAL. Natal, 1997. Anais. Brasília: SOBER, 1997.

LOPES, A . I .S. Integration Espacial de los mercados de porcino europeus. Zaragoza, 1996. 219p. Diss. (Mestrado) Centro Internacional de Estudos Agronômicos Mediterrâneos.

LOPES, M.R. Importações Acumulam estoques nas mãos do governo. Conjuntura Econômica, p.58-59, nov. 1995 b.

LOPES, M.R. Mercado agrícolas e o processo de integração no Mercosul. In: BRANDÃO, A.S. e PEREIRA (ed.) Mercosul: perspectivas de integração. Rio de Janeiro. Ed. da Fundação Getúlio Vargas, 1996, 306p. 
LOPES, M.R. O imposto compensatório sobre subsídios na Origem e Prática de "Dumping" nos mercados agrícolas: Um estudo preliminar no caso do Brasil. Comércio Internacional e comercialização agrícola. In: TEIXEIRA, E.C; AGUIAR, D.R. (ed.) Viçosa: 1995a, p 68-97.

LOPES, M.R. Reformas Agrícolas: os custos dos ajustes parciais. Conjuntura Econômica, p.25-29, jul. 1994.

MENDONÇA DE BARROS, MIRANDA, E.F. Agricultura e Estabilização no Brasil, 1995-98. Brasília, EMBRAPA, 1998, 18 1p.

MONKE, PETZEL, T. Market Integration. American Journal of Agricultural Economics. v. 66, n. 4, p.481-487, nov. 1984.

MONTOYA, M.A. A matriz insumo-produto internacional do Mercosul em 1990: as desigualdades regionais e o impacto intersetorial do comércio inter-regional . Piracicaba, 1998. p.217, Tese (Doutorado) - Escola Superior de Agricultura "Luiz de Queiroz", Universidade de São Paulo.

NETTO, V.S.N; CAMPOS, A . C; Impactos do Mercosul na produção e comercialização de milho e soja na região Centro-Oeste. Revista de Política Agrícola, ano n. 4, out-dez. 1995.

OFFICER, L.H. The Law of one price cannot be rejected: two tests based on the tradable/ nontradable price ratio. Journal of Macroeconomics, v. 8, n.2, p.159182, 1986.

OSTERWALD- LENUM, M. Practitioner's Corner - A note with quantities of the Asymptotic Distribution of the Maximum Likelihood Cointegration Rank Test Statistic. Oxford Bulletin of Economic and Statistics, v.54, n. 3, p.462-472, 1992. PICK, D.H.; PARK, T. A. The competitive structure ou U.S. Agricultural Exports. American Journal of Agricultural Econonomics, v. 73, n. 1, p.133-141, 1991. PROTOPAPADAKIS, A; STOLL, H.R. Spot and futures prices and the law of one price. The journal of finance, v. XXXVIII, n. 5, p.1431-1455, dez. 1983.

RAVALliON, M. Testing market integration. American Journal of Agricultural Economics. v. 68, n. 1. p.102-109. feb. 1986.

Revista Brasileira de Comércio Exterior - RBCE. Edição especial, fev. 1992, p.3749. A política de oferta: Importação e Produção doméstica. 
REZENDE, G.C. Ajuste externo e agricultura no Brasil, 1981-1986. Revista Brasileira de Economia, v. 42, n.2, p.101- 137. abr.-jun, 1988.

REZENDE, G.C., NONNENBERG, M.J.B. MARQUES, M.C.. Abertura Comercial, Financiamento das Importações e o Imposto sobre o setor agrícola. Rio de Janeiro, IPEA, jul. 1997. (Texto para discussão no. 498).

RICHARDSON, D.J. Some Empirical evidence on commodity arbitrage and the law of one price. Journal of International Economis, n.8, p.341-351, 1978.

SAMUELSON, P.A. Spatial price equilibrium and linear programing. American Economic Review, v. 42, p.283-303, 1952.

SANTO, B.R., SEVERO, J.R. Abertura externa e o saldo da balança comercial agrícola. Preços Agrícolas. p. 10-21, ago. 1997.

SANTOS, C.V. Uma avaliação da proteção efetiva na agricultura paranaense no período 1985-96. . Piracicaba. 1998, 113p. Dissertação (Mestrado) - Escola Superior "Luiz de Queiroz" (ESALQ), Universidade de São Paulo.

TAKAYAMA, T. JUDGE, J.J. Spatial and temporal price and allocation models. Amsterdan: North-Holand Publishing, 1971.

THORSTENSEN, V. et. al. O Brasil frente a um mundo dividido em blocos. São Paulo: Nobel, 1994. 277 p.

URBAN, M.L.P; BESEN, G.M.V; Gonçalves, J.S; Souza, S. A. M. Estado e produção têxtil: Uma discussão de políticas públicas. Informações Econômicas, v.25, n.11, nov.1995, p.37-67.

URBAN, M.L.P; BESEN. G.M.V; Gonçalves, J.S; Souza, S. A. M. Desenvolvimento da produção de Têxteis de Algodão no Brasil. Informações Econômicas, v.25, n. 12, p.11-28, dez.1995.

WADDINGTON, S. BRAZ, C.F.S. Evolução da Economia Mundial. In: A economia brasileira em perspectiva - 1996. Rio de Janeiro: IPEA, 1996. v.1, p.141-157. WILLIAMS, C.H. BEWLEY, R.A. Price Arbitrage between Queensland Catte Auctions. Australian Journal of Agricultural Economics. v. 37, n. 1, pp. 33-55, 1993. ZINI Jr, A . A . A taxa de câmbio e política cambial no Brasil. São Paulo: Editora da Universidade de São Paulo, 1993. 
ZYLBERSTAJN. D. JANK, M.S. Agribusiness e Mercosul: construindo um novo aparato institucional. VI SEMINÁRIO INTERNACIONAL PENSA. Canela, 15 a 18 de setembro de 1996. 
APÊNDICE 
Quadro. A.1 - Preços médios mensais de fretes marítimos de milho para o brasil - US $\$ / t$.

\begin{tabular}{|c|c|c|c|c|c|c|c|c|c|c|c|c|c|}
\hline $\begin{array}{c}\text { ANO/ } \\
\text { ORIGEM }\end{array}$ & jan & fev & mar & abr & mai & Jun & jul & ago & Set & out & nov & dez & média \\
\hline $1994 \mathrm{ARG}^{1}$ & 18 & 18 & 18 & 18 & 18 & 18 & 18 & 18 & 18 & 18 & 18 & 18 & 18 \\
$1994 \mathrm{EUA}$ & 19 & 19 & 19 & 19 & 19 & 19 & 19 & 19 & 19 & 19 & 19 & 19 & 19 \\
$1995 \mathrm{ARG}^{1}$ & 18 & 18 & 18 & 18 & 18 & 18 & 18 & 18 & 18 & 18 & 18 & 18 & 18 \\
$1995 \mathrm{EUA}^{1}$ & 19 & 19 & 19 & 19 & 19 & 19 & 19 & 19 & 19 & 19 & 19 & 19 & 19 \\
$1996 \mathrm{ARG}^{1}$ & 18 & 18 & 18 & 18 & 18 & 18 & 18 & 18 & 18 & 18 & 18 & 18 & 18 \\
$1996 \mathrm{EUA}^{1}$ & 19 & 19 & 19 & 23 & 23 & 23 & 23 & 23 & 23 & 23 & 23 & 23 & 22 \\
$1997 \mathrm{ARG}^{1}$ & 19 & 19 & 19 & 19 & 19 & 19 & 19 & 19 & 19 & 19 & 19 & 19 & 19 \\
$1997 \mathrm{EUA}^{1}$ & 23 & 23 & 23 & 23 & 23 & 23 & 23 & 23 & 23 & 23 & 23 & 23 & 23 \\
$1998 \mathrm{ARG}^{1}$ & 19 & 19 & 19 & 18 & 18 & 17 & 15 & 15 & 15 & 15 & 15 & & 17 \\
$1998 \mathrm{EUA}^{2}$ & 23 & 23 & 23 & 19 & 19 & 18 & 16 & 16 & 16 & 16 & 16 & & 19 \\
& & & & & & & & & & & & & \\
\hline
\end{tabular}

Fonte: Refinações de Milho Brasil.

${ }^{1}$ Argentina.

Quadro. A.2 - Custos de fretes para transportes de arroz para o Brasil origens Uruguai e Argentina

\begin{tabular}{|l|c|}
\hline ORIGEM/CIDADE DESTINO & CUSTO (US\$/t) \\
\hline URUGUAI PARA PELOTAS (RS) & 14,00 \\
\hline Rio Branco & 20,00 \\
Melo & 18,00 \\
Tuy Tres & 24,00 \\
Tupambaé & \\
\hline URUGUAI PARA ITAQUI (RS) & 32,00 \\
\hline Tacuarambó & 18,00 \\
Tomas Gomensoro & 25,00 \\
Salto & \\
\hline ARGENTINA (ENTRE RIOS) PARA ITAQUI (RS) & 33,00 \\
& 24,00 \\
Balsavilbaso & 27,00 \\
Chajari & 28,00 \\
Concórdia & \\
Urdinarram &
\end{tabular}

Fonte: IRGA 
Tabela A.1 - Eleição do número de defasagens do modelo VAR

SÉRIES MILHO 90/98

\begin{tabular}{ccc} 
DEFASAGENS $(\mathrm{p})$ & AKAIKE $(\mathrm{p})$ & SCHWARZ $(\mathrm{p})$ \\
\hline 12 & -29928 & $-2831,1$ \\
8 & $-3014,3$ & -29098 \\
6 & $-3035,2$ & $-2945,8$ \\
3 & $-3101,5$ & $-3062,7$ \\
2 & $-3077,2$ & 3038,3
\end{tabular}

SÉRIES ARROZ 90/98

\begin{tabular}{ccc} 
DEFASAGENS $(\mathrm{p})$ & AKAIKE $(\mathrm{p})$ & SCHWARZ $(\mathrm{p})$ \\
\hline 12 & $-2201,9$ & $-2072,5$ \\
8 & $-2040,9$ & $-1944,7$ \\
6 & $-2094,7$ & $-2023,2$ \\
3 & $-2093,1$ & $-2051,7$ \\
2 & $-2110,2$ & $-2079,1$
\end{tabular}

SÉRIES ALGODÃO 90/98

\begin{tabular}{ccc}
\hline DEFASAGENS $(\mathrm{p})$ & AKAIKE $(\mathrm{p})$ & SCHWARZ $(\mathrm{p})$ \\
\hline 12 & $-2376,0$ & $-2278,9$ \\
8 & $-2466,3$ & $-2397,9$ \\
6 & $-2506,4$ & 2452,8 \\
3 & $-2569,3$ & $-2540,9$ \\
2 & $-2580,0$ & $-2550,7$ \\
\hline DEFASAGENS $(\mathrm{p})$ & SÉRIES ALGODÃO 94/97 & \\
\hline 6 & AKAIKE $(\mathrm{p})$ & SCHWARZ(p) \\
\hline 3 & $-2002,2$ & $-1942,2$ \\
2 & $-1861,2$ & $-1825,5$ \\
\hline
\end{tabular}

$\overline{\text { Fonte: Dados da pesquisa }}$ 